\title{
DESEMPENHO DE CULTIVARES DE TOMATE (Lycopersicon esculentum Mill.) SOB SISTEMAS ORGÂNICOS EM CULTIVO PROTEGIDO
}

\author{
LUCIANO GRASSI TAMISO
}

\begin{abstract}
Dissertação apresentada à Escola Superior de Agricultura "Luiz de Queiroz", Universidade de São Paulo, para obtenção do título de Mestre em Agronomia, Área de Concentração: Fitotecnia.
\end{abstract}

P I R A C I C A B A

Estado de São Paulo - Brasil Março - 2005 


\title{
DESEMPENHO DE CULTIVARES DE TOMATE (Lycopersicon esculentum Mill.) SOB SISTEMAS ORGÂNICOS EM CULTIVO PROTEGIDO
}

\author{
LUCIANO GRASSI TAMISO
}

Engenheiro Agrônomo

Orientador: Prof. Dr. PAULO CÉSAR TAVARES DE MELO

\begin{abstract}
Dissertação apresentada à Escola
Superior de Agricultura "Luiz de

Queiroz", Universidade de São Paulo, para obtenção do título de Mestre em Agronomia, Área de Concentração: Fitotecnia.
\end{abstract}

PIR A C I C A B A

Estado de São Paulo - Brasil Março - 2005 
Dados Internacionais de Catalogação na Publicação (CIP) DIVISÃO DE BIBLIOTECA E DOCUMENTAÇÃO - ESALQ/USP

Tamiso, Luciano Grassi

Desempenho de cultivares de tomate (Lycopersicon esculentum Mill.) sob sistemas orgânicos em cultivo protegido / Luciano Grassi Tamiso. - - Piracicaba, 2005.

87 p. : il.

Dissertação (mestrado) - - Escola Superior de Agricultura Luiz de Queiroz, 2005.

Bibliografia.

1. Agricultura orgânica 2. Cultivo protegido 3. Tomate I. Título

CDD 635.642

"Permitida a cópia total ou parcial deste documento, desde que citada a fonte - $\mathrm{O}$ autor" 
Aos meus pais, Álvaro e M. Lourdes,

pelo amor, apoio e confiança que

permitiram meu crescimento

como ser humano, DEDICO.

Em memória do Prof. Dr. João Tessarioli Neto, pela amizade e orientação na graduação e nos primeiros meses da pós-graduação, OFEREÇo 


\section{AGRADECIMENTOS}

A Deus, pela força concedida nos momentos de desânimo e decepção, tornando possível a conclusão deste trabalho;

Ao Prof. Dr. Paulo César Tavares de Melo, pela preciosa orientação, pela confiança, dedicação, incentivo e paciência;

Aos produtores Marcelo Oyafuso e Marcelo Akira Saito, por gentilmente cederem suas áreas para realização dessa pesquisa,

Ao Dr. Edmilson Ambrosano, da APTA Regional - Pólo Centro-Sul, pelo apoio e amizade durante todo o curso;

A Dra. Eliana Schmanss, do Instituto de Zootecnia, pelo auxílio na realização da análise estatística;

Ao Prof. Dr. Mario M. Inomoto, do Departamento de Entomologia, Fitopatologia e Zoologia Agrícola, da ESALQ-USP, pelas análises realizadas;

Ao Prof. Dr. Hiroshi Kimati, da clínica Fitopatológica do Departamento de Entomologia, Fitopatologia e Zoologia Agrícola da ESALQ-USP, pelas análises realizadas;

Aos estagiários Marcos Eduardo Mitsuo Sasaki e Elisa Miyuki Mizumoto, pelo auxílio na realização do projeto,

Aos meus amigos da República, pelo bom convívio, amizade e respeito;

A todos, que de alguma forma, contribuíram para a realização deste trabalho.

Obrigado. 


\section{SUMÁRIO}

Página

LISTA DE TABELAS..................................................................... viii

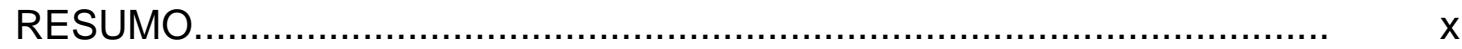

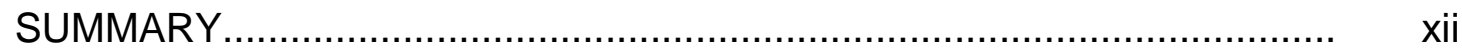

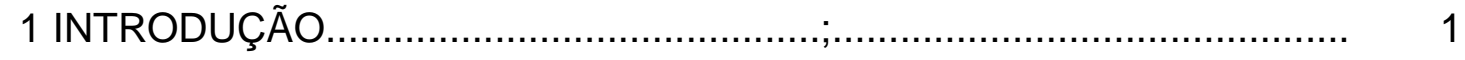

2 REVISÃO DE LITERATURA................................................... 3

2.1 Agricultura Orgânica.............................................................. 3

2.1 .1 Segurança alimentar.......................................................... 3

2.1.2 Movimentos alternativos.................................................. 4

2.1.3 Definições e conceitos......................................................... 6

2.1 .4 Certificação................................................................... 8

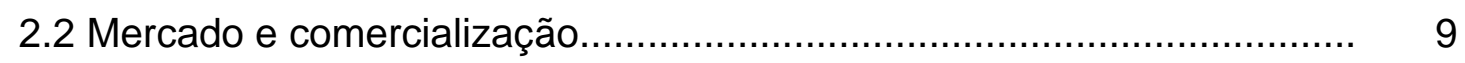

2.2.1 Mercado mundial................................................................. 9

2.2.2 Mercado brasileiro................................................................ 10

2.3 Tomaticultura orgânica............................................................. 12

2.3.1 Aspectos gerais................................................................ 12

2.3.2 Manejo orgânico................................................................. 14

2.3.2.1 Cultivares de polinização livre (PL) versus híbridos........................ 16

2.3.2.2 Sistemas de condução............................................................ 17

3 MATERIAIS E MÉTODOS............................................................ 20

3.1 Local de instalação dos experimentos............................................. 20

3.1.1 Experimento I - Ibiúna, SP............................................... 20

3.1.2 Experimento II - Araraquara, SP........................................... 22 


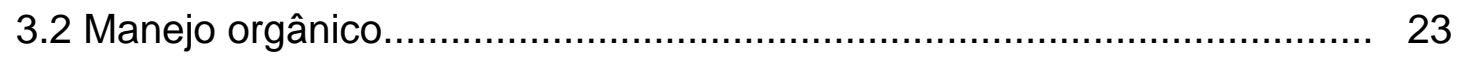

3.2.1 Experimento I - Ibiúna, SP.................................................. 23

3.2.2 Experimento II - Araraquara, SP ............................................. 25

3.3 Cultivares avaliados........................................................... 27

3.4 Delineamento experimental.................................................... 29

3.5 Parâmetros avaliados............................................................ 31

3.5.1 Características de produção.................................................. 31

3.5.2 Características do fruto................................................... 31

3.5.3 Avaliação de danos fitossanitários.......................................... 32

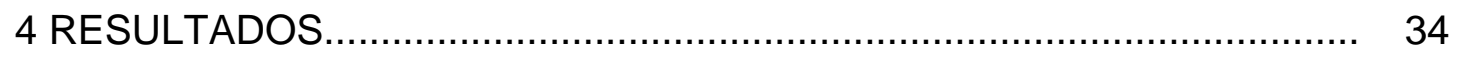

4.1 Experimento I, Ibiúna, SP....................................................... 34

4.1.1.Componentes da produção......................................................... 34

4.1.1.1 Peso total (PT) e comercial (PC) de frutos................................. 34

4.1.1.2 Número total (NT) e comercial (NC) de frutos.............................. 35

4.1.1.3 Peso médio de frutos comerciais (FM) e número médio de frutos por

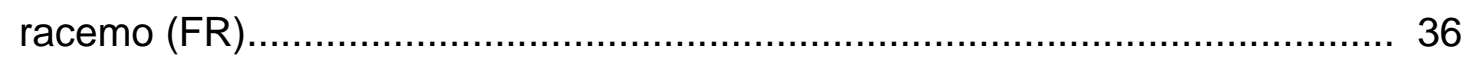

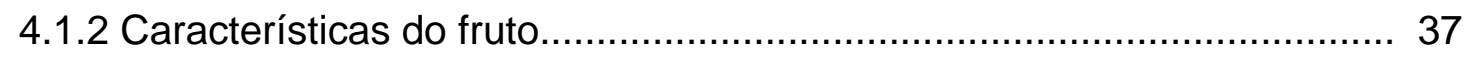

4.1.2.1 Classificação comercial dos frutos (CC)....................................... 37

4.1.2.2 Número de lóculos, cicatriz peduncular e firmeza de frutos .............. 39

4.1.2.3 Danos fitossanitários.............................................................. 40

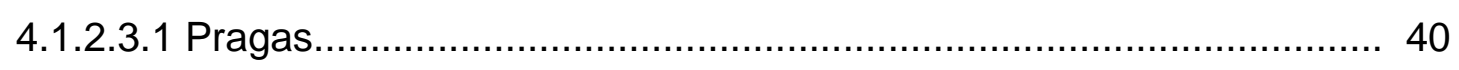

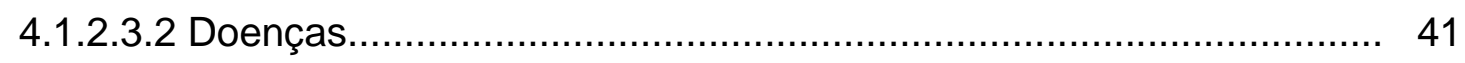

4.2 Experimento II, Araraquara, SP............................................... 43

4.2.1 Componentes da produção....................................................... 43

4.2.1.1 Peso total (PT) e comercial (PC) de frutos................................ 43

4.2.1.2 Número total (NT) e comercial (NC) de frutos.............................. 44

4.2.1.3 Peso médio de frutos comerciais (FM) e número médio de frutos por

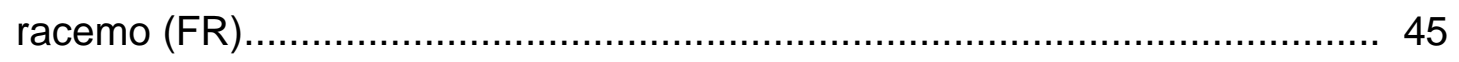

4.2 .2 Características do fruto......................................................... 46

4.2.2.1 Classificação comercial dos frutos (CC) .................................... 46 
4.2.2.2 Número de lóculos, cicatriz peduncular e firmeza de frutos............... 47

4.2.2.3 Danos fitossanitários.............................................................. 48

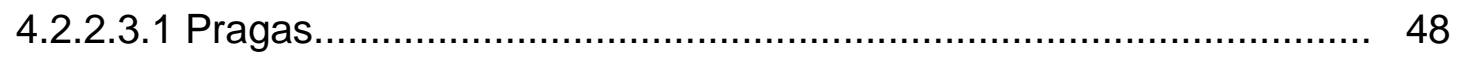

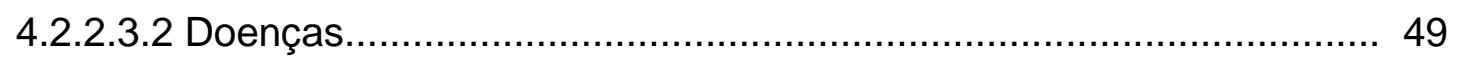

4.3 Comparações entre os experimentos........................................... 51

4.3.1 Componentes da produção...................................................... 52

4.3.2 Características do fruto........................................................... 54

4.3.2.1 Classificação comercial dos frutos (CC).................................... 54

4.3.2.2 Danos fitossanitários.......................................................... 54

4.3.2.3 Adaptação dos cultivares..................................................... 55

4.3.2.4 Produção comercial................................................................. 56

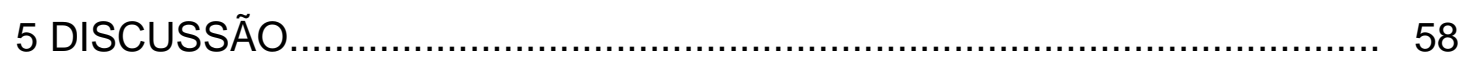

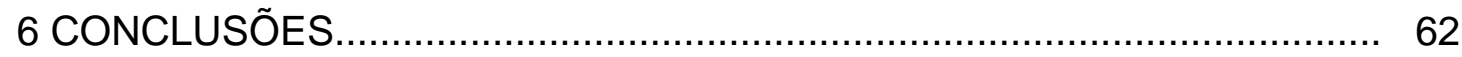

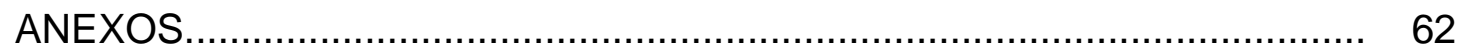

REFERÊNCIAS BIBLIOGRÁFICAS ................................................ 69 


\section{LISTA DE TABELAS}

Página

1 Agricultura orgânica no mundo........................................................ 22

2 Culturas com maiores áreas de produção sob manejo orgânico e número de

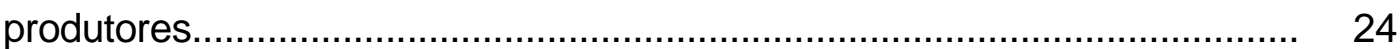

3 Resultado da análise de solo da área do experimento I, Ibiúna, SP......... 33

4 Resultado da análise de solo da área do experimento II, Araraquara, SP.. 34

5 Descrição dos cultivares de tomate testados nos experimentos I e II, conduzidos em Ibiúna, SP e Araraquara, SP, 2004.............................. 39

6 Médias de produção total (PT) e comercial (PC) de frutos, e porcentagem da produção de frutos comerciais, experimento I, Ibiúna, SP, 2004............. 47

7 Médias do número total (NT) e comercial (NC) de frutos e porcentagem do número de frutos comerciais, experimento I, Ibiúna, SP, 2004.............. 48

8 Médias de peso de frutos comerciais (FM) e do número de frutos por racemo (FR), experimento I, Ibiúna, SP, 2004

9 Porcentagem de frutos dentro das oito classes de diâmetro equatorial (em mm), experimento I, Ibiúna-SP, 2004

10 Número de lóculos (NL), tamanho da cicatriz peduncular (CP) e firmeza do fruto (FF), experimento I, Ibiúna, SP, 2004................................... 51

11 Número e porcentagem de frutos danificados pela traça-do-tomateiro nos cultivares avaliados no experimento I, Ibiúna, SP, 2004

12 Nível de infestação e espécies de nematóides identificados nos cultivares avaliados no experimento I, Ibiúna, SP, 2004. 
13 Nível de incidência de Requeima (PI) e de Mancha-de-cladospório (FF), experimento I, Ibiúna, SP, 2004.................................................. 54

14 Médias de produção total (PT) e comercial (PC) de frutos, e porcentagem da produção de frutos comerciais, experimento II, Araraquara, SP, 2004.. 56

15 Médias do número total (NT) e comercial (NC) de frutos e porcentagem do número de frutos comerciais, experimento II, Araraquara, SP, 2004... 57

16 Médias de peso de frutos comerciais (FM) e do número de frutos por racemo (FR), experimento II, Araraquara, SP, 2004.................................. 58

17 Porcentagem de frutos dentro das oito classes de diâmetro equatorial (em $\mathrm{mm})$, experimento II, Araraquara-SP, 2004.................................... 59

18 Número de lóculos (NL), tamanho da cicatriz peduncular (CP) e firmeza do fruto (FF), experimento II, Araraquara, SP, 2004.............................. 59

19 Porcentagens de danos causados nos frutos pelas pragas que ocorreram no

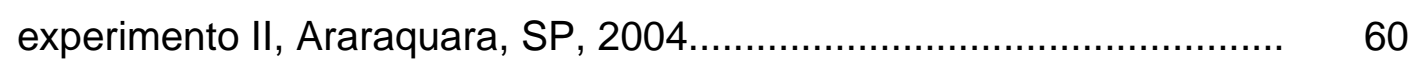

20 Nível de infestação e espécies de nematóide presente nos cultivares avaliados, experimento II, Araraquara, SP, 2004.............................. 61

21 Média de produção total (PT) e comercial (PC) de frutos, e porcentagem da produção comercial de frutos, experimento I e II, SP, 2004................. 64

22 Médias do número total (NT) e comercial (NC) de frutos e porcentagem do número de frutos comerciais, experimento I e II, SP, 2004.................... 65

23 Médias de peso de frutos comerciais (FM) e do número de frutos por racemo

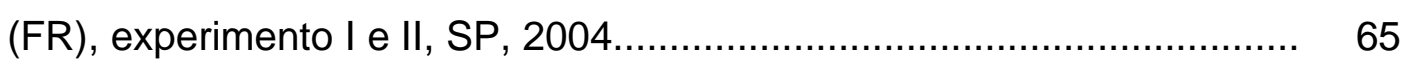

24 Porcentagem de frutos dentro das oito classes de diâmetro equatorial (em

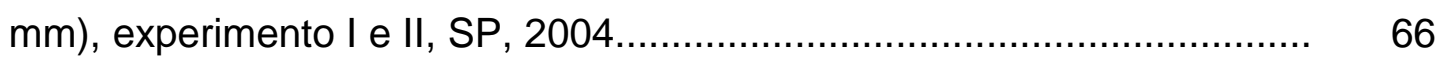

25 Porcentagem de danos causados nos frutos pelas pragas que ocorreram nos experimentos I e II, Araraquara-SP, 2004............................................ 67 


\section{DESEMPENHO DE CULTIVARES DE TOMATE (Lycopersicon esculentum Mill.) SOB SISTEMAS ORGÂNICOS EM CULTIVO PROTEGIDO}

Autor: LUCIANO GRASSI TAMISO

Orientador: Prof. Dr. PAULO CÉSAR TAVARES DE MELO

\section{RESUMO}

A Agricultura Orgânica no Brasil cresce a taxas superiores a $30 \%$ ao ano, devido, principalmente, a uma maior conscientização dos consumidores, que buscam hábitos alimentares mais saudáveis. Dentre as hortaliças, o tomate orgânico representa uma boa oportunidade de investimento para o produtor. No entanto, não existem recomendações técnicas ou genótipos desenvolvidos exclusivamente para esse sistema de produção, o que dificulta a expansão da área sob manejo orgânico. Diante disso, o presente trabalho teve como objetivo avaliar o desempenho de 11 cultivares de tomate (Avalon, Colibri, HTX - 5415, HTX - 8027, Sahel, San Marzano, San Vito, Júpiter, Raminho, Saladete DRW 3410 e Jane) sob dois sistemas orgânicos distintos em ambiente protegido, de março a outubro de 2004, nos municípios de Ibiúna, SP (experimento I) e Araraquara, SP (experimento II). Os experimentos foram conduzidos em propriedades que produzem tomate orgânico em escala comercial. No experimento I, as plantas foram conduzidas em linhas simples, com uma haste 
e com poda apical drástica, realizada acima do terceiro racemo. As estufas eram conjugadas, e a irrigação realizada por gotejo, utilizado também para a fertiirrigação com biofertilizantes. O espaçamento adotado foi de 1,5 m entre linhas e $0,35 \mathrm{~m}$ entre plantas. No experimento $\mathrm{II}$, as estufas não eram conjugadas, e as plantas foram conduzidas em fileiras duplas, com duas hastes por planta, sem poda apical, no espaçamento de 0,8 m entre linhas e 0,6 m entre plantas. Em ambos os experimentos a densidade de plantio foi de 20 mil plantas por hectare. O delineamento experimental adotado foi em blocos ao acaso, com cinco repetições e dez tratamentos (Avalon, Colbri, HTX - 5415, HTX - 8027, Sahel, San Marzano, San Vito, Júpiter, Raminho e Saladete DRW 3410), para o experimento I, e quatro repetições e oito tratamentos (Avalon, Colbri, HTX - 5415, HTX - 8027, Sahel, San Marzano, San Vito, e Jane) para o experimento II. Considerando as condições em que os experimentos foram desenvolvidos, os resultados permitiram concluir que o híbrido Sahel mostrou o melhor desempenho para rendimento comercial, e para outros componentes da produção nos dois sistemas de condução ao qual foi submetido. No experimento I, destacaram-se, ainda, os híbridos Colibri e Saladete DRW 3410, que não diferiram estatisticamente de 'Sahel'. Os híbridos, de um modo geral, mostraram melhor desempenho que os cultivares de polinização livre, porém, apenas "Sahel" mostrou maior amplitude adaptativa. No experimento I, conduzido com poda apical drástica, a porcentagem de frutos de melhor cotação comercial foi maior do que no experimento II, sem poda apical. O experimento I, também apresentou período de colheita menor e mais concentrado do que no experimento II. A traça-do-tomateiro revelou-se como fator limitante afetando significativamente o rendimento comercial. 


\section{PERFORMANCE OF TOMATO CULTIVARS (Lycopersicon esculentum Mill.) ORGANICALLY-GROWN UNDER GREENHOUSE CONDITIONS}

Author: LUCIANO GRASSI TAMISO

Adviser: Prof. Dr. PAULO CÉSAR TAVARES DE MELO

\section{SUMMARY}

Organic agriculture in Brazil has increased about 30\% over the last few years since consumers are seeking for healthier foods, i.e. nutritious and free of pesticide residues. Among vegetable crops organically-grown, tomato constitutes an attractive economic opportunity for growers. However, the lack of information about management practices and cultivars adapted to organic production systems under protected cultivation are pointed out as important constraints that prevents this activity to expand. This work aimed to evaluate the performance of 11 indeterminate tomato cultivars (Avalon, Colibri, HTX - 5415, HTX - 8027, Sahel, San Marzano, San Vito, Júpiter, Raminho Sel. IPA, Saladete DRW 3410 and Jane) under two different organic management systems in unheated plastic greenhouse. Two experiments were carried out under climatically different areas of the State of São Paulo (experiment I, Ibiúna county, and experiment II in Araraquara county), from March to October 2004, in farms that commercially produce organic tomatoes under unheated plastic 
greenhouses. In both experiments tomato plants were staked. Tomato plants in experiment I were conducted with a single stem and apical bud removed upper $3^{\text {rd }}$ cluster. The experiment was fertigated using with biofertilizers. Plant spacing was $1.5 \mathrm{~m}$ between rows and $0.35 \mathrm{~m}$ between plants. In experiment II, tomato plants were conducted with two stems without apical pruning. They were planted in double line and spaced $0.8 \mathrm{~m}$ between lines and $0.6 \mathrm{~m}$ between plants. $\mathrm{In}$ both experiments plant density was about 20,000 plants ha ${ }^{-1}$. Experiments were set up in a randomized complete block design. Experiment I had five replications and ten treatments, and experiment II four replications and eight treatments. Sahel hybrid exhibited an outstanding performance for marketable yield in both organic systems but, in experiment I did not differ statistically from hybrids Colibri and Saladete DRW 3410. Hybrid cultivars, in general, outperformed open pollinated cultivars for the evaluated parameters. Apical pruning had significant effect on the increase of tomato fruits graded as of better commercial acceptance (50-60 $\mathrm{mm}$ ) and also was associated with concentration of the picking period. It was found that tomato pinworm (Tuta absoluta) constitutes a serious limiting pest for organically-grown tomatoes in both regions where the experiments were set up. 


\section{INTRODUÇÃO}

Nos últimos anos o mercado de produtos orgânicos vem crescendo a taxas que chegam a 30\% ao ano. Estima-se que, em 2004, o mercado mundial desse novo segmento alimentar tenha movimentado mais de US\$ 26 bilhões, contra apenas US\$ 10 bilhões em 1997, representando um crescimento ao redor de 160\%, em menos de 10 anos (Ormond, 2002).

No Brasil, esses produtos movimentaram US\$300 milhões em 2003, e crescem entre 30\% e 50\% ao ano (Kiss, 2004). As exportações são de US\$ 100 milhões, segundo dados da APEX (Agência de Promoção de Exportações do Brasil). (Agrofolha, 2005).

O crescimento do mercado de produtos orgânicos, no contexto mundial, é devido a maior conscientização dos consumidores, que buscam hábitos alimentares mais saudáveis, e preocupam-se com a segurança dos alimentos que adquirem, quanto à ausência de resíduos químicos decorrentes da aplicação abusiva de agrotóxicos.

Para o setor produtivo, o maior atrativo da produção orgânica, inicialmente, pode estar relacionado ao preço substancialmente maior alcançado no mercado, em comparação ao produto similar produzido por via convencional. No entanto, os produtores interessam-se por esse sistema devido à possibilidade de redução de custos com insumos, pela conscientização da redução de impactos ambientais e melhor funcionamento dos agroecossistemas (Diver et al., 1999). 
No Brasil, a participação das oleráceas no mercado de orgânicos é ainda incipiente, representando apenas 1,1\% da área total cultivada (Ormond, 2002).

Dentre as hortaliças cultivadas no país, o tomate para mesa destaca-se em área plantada (40 mil ha) e em produção (1,9 milhão de toneladas), sendo cultivado em todas as regiões geográficas sob diferentes sistemas de manejo cultural (Melo, 2003).

Devido ao grande número de pragas e doenças que afetam o tomateiro, essa cultura ocupa o segundo lugar em consumo de agrotóxicos por área (Neves, 2003). A demanda por tomate produzido organicamente vem crescendo em resposta à divulgação freqüente, pela mídia, de contaminação do produto por resíduos de pesticidas (ANVISA, 2005). Desse modo, a produção orgânica de tomate constitui, ao mesmo tempo, uma excelente oportunidade de negócio e um grande desafio para os produtores, que não dispõem de informações relativas a cultivares adaptadas especificamente ao cultivo orgânico, bem como de técnicas de manejo cultural e de controle de pragas e doenças.

O presente trabalho teve por objetivo estudar o comportamento de cultivares de tomate de porte indeterminado quanto aos componentes de produção e à qualidade dos frutos, em dois sistemas de cultivo orgânico, em ambiente protegido. 


\section{REVISÃO DE LITERATURA}

\subsection{Agricultura Orgânica}

\subsubsection{Segurança alimentar}

O risco de ocorrência de doenças associadas ao consumo de alimentos contendo aditivos, pesticidas, hormônios, toxinas naturais ou outras substâncias, tem contribuído para gerar insegurança e despertar preocupação no consumidor. A cada dia aumentam as exigências dos consumidores em adquirir produtos isentos de risco. A segurança alimentar, com ênfase em aspectos qualitativos, pode ser entendida como a aquisição, pelo consumidor, de alimentos com boa qualidade, livre de contaminantes de naturezas química, biológica, física ou qualquer substância que possa acarretar problemas à saúde (Spers \& Kassouf, 1996). Os autores enfatizam, ainda, que o conceito de segurança, do ponto de vista qualitatitvo, também está associado a uma alimentação mais saudável, rica em fibras e vegetais. Percebe-se que os princípios de produção agrícola, adotados em sistemas orgânicos, alinham-se com as idéias de segurança alimentar expressas pelos autores, uma vez que, nesse sistema de produção, a exigência por produtos livres de contaminantes nocivos a saúde humana é fator normativo.

De acordo com Borguini (2002), numa pesquisa que buscou conhecer o perfil do consumidor de tomate orgânico, observou-se que a ausência de pesticidas é um dos fatores decisivos na opção por esses produtos. No entanto, 
os seus preços elevados e a falta de disponibilidade restringem o seu consumo. Ainda é relativamente recente, a atenção dispensada para esses alimentos no Brasil, e o consumidor caracteriza-se por ser bem informado e ter alto poder aquisitivo.

\subsubsection{Movimentos alternativos}

Diversos sistemas alternativos de produção foram desenvolvidos em resposta ao questionamento da sociedade sobre a sustentabilidade da agricultura moderna. Entre tais sistemas, a Agricultura Orgânica tem atraído a atenção do setor produtivo mundial, por resgatar os princípios e os mecanismos que operam na natureza em substituição aos insumos tradicionais (Edwards, 1989; Diver et al., 1999 e Bettiol, 2004).

Os primeiros movimentos em oposição à agricultura moderna começaram na década de 1920. Foi nesse período, na Inglaterra, que o agrônomo Albert Howard começou a difundir seus conhecimentos. Através de suas observações, Howard percebeu que a adubação química produzia excelentes resultados nos primeiros anos, mas depois, os rendimentos caiam drasticamente, enquanto que os métodos de adubação tradicional dos camponeses, baseados em uso de excrementos animais com restos de cultura, cinzas e ervas daninhas, resultavam em colheitas menores, porém constantes. Iniciava-se uma nova vertente denominada Agricultura Orgânica (Kathounian, 2001).

Nessa mesma época, na Alemanha, o berço da química agrícola, o filósofo Rudolf Steiner começou a cristalizar os alicerces de um movimento baseado na ciência antroposófica e que, mais tarde, ficaria conhecida como Agricultura Biodinâmica. Tal corrente entende a propriedade como um organismo e destaca a presença de animais como um dos elementos centrais para o equilíbrio do sistema (Kathounian, 2001). 
No início dos anos 30, uma outra corrente chamada de Agricultura Biológica, começou a se disseminar através dos trabalhos do Dr. Hans Peter Muller sobre fertilidade do solo e microbiologia. Nos anos 60, na França, Claude Aubert sistematizou os fundamentos teóricos dessa nova vertente no livro L`agriculture Biologique: pourquoi et comment la pratiquer. No entanto, o maior representante desse movimento foi Francis Chaboussou que, em 1980, publicou o livro Plantas doentes pelo uso de agrotóxicos. Essa obra disserta sobre a Teoria da Trofobiose, que é um dos pilares da Agricultura Orgânica. Chaboussou defende, através de trabalhos próprios e de literatura científica, que a composição da seiva da planta pode ser alterada pelos fertilizantes químicos e agrotóxicos, tornando a planta mais propícia para a multiplicação de pragas e doenças (Kathounian, 2001; Penteado, 2004).

No Japão, nas décadas de 30 e 40, Mokiti Okada desenvolveu um movimento de caráter filosófico-religioso que resultou na criação da Igreja Messiânica. Um dos pilares desse movimento é o método denominado de Agricultura Natural, que preconiza a menor alteração possível no funcionamento natural dos ecossistemas. A Agricultura Natural difere das demais, por utilizar somente resíduos vegetais na adubação, excluindo qualquer excremento animal, e pelo uso do EM (microorganismos eficientes) (Kathounian, 2001).

Na Austrália, concretizou-se o movimento da Permacultura, que prega a idéia da criação de agroecossistemas sustentáveis por meio da simulação de ecossistemas naturais, caminhando para a priorização das culturas perenes como elemento central da proposta.

$\mathrm{Na}$ América Latina, surgiu o movimento denominado de Agroecologia, que tem, como principal destaque, o chileno Miguel Altieri. Tal movimento procura atender, simultaneamente, as necessidades de preservação ambiental e de promoção sócio-ecônomica dos pequenos agricultores. Quando se fala de Agroecologia, está se tratando de uma ciência cuja contribuição vai muito além de aspectos meramente tecnológicos ou agronômicos da produção. Ela incorpora dimensões mais amplas e complexas, que incluem tanto variáveis 
econômicas, sociais e ambientais, como também culturais, políticas e éticas da sustentabilidade. Afasta-se, assim, a idéia equivocada de Agroecologia como um tipo de agricultura, um sistema de produção ou uma tecnologia agrícola. (Caporal, 2004).

Com o crescimento da produção e do mercado mundial para os produtos orgânicos, surgiu a necessidade da criação de um órgão internacional com o objetivo de estabelecer padrões mínimos de qualidade para todos os movimentos alternativos, e realizar o intercâmbio de experiências. A partir de 1972, foi fundada a International Federation of Organic Agriculture Moviments (Federação Internacional dos Movimentos de Agricultura Orgânica) - IFOAM, e decidiu-se pela adoção do termo "orgânico" como coletivo de todas as correntes alternativas e contrárias ao sistema convencional predominante.

\subsubsection{Definições e conceitos}

A Agricultura Orgânica vem sendo definida de diferentes maneiras pelos especialistas, devido à diversidade de sistemas de produção incluídos no conceito orgânico. Assim, para Caporal (2004), Agricultura Orgânica é o resultado das aplicações de técnicas e métodos diferenciados dos pacotes convencionais, normalmente estabelecidos de acordo e em função de regulamentos e regras que orientam a produção e impõem limites ao uso de certos tipos de insumos e a liberdade para o uso de outros. Carvalho (2000), por sua vez, definiu Agricultura Orgânica como um conjunto variado de tecnologias e práticas agrícolas voltadas para enaltecer as condições particulares de cada ecossistema, na produção agropecuária. Outra definição, dada pelo Comitê Nacional de Padrões Orgânicos dos Estados Unidos (1998) conceitua Agricultura Orgânica como um sistema de manejo ecológico que promove e incrementa a biodiversidade, os ciclos biológicos e a atividade biológica do solo, sendo baseada no uso mínimo de insumos externos e em 
práticas de manejo que restaurem, mantenham e incrementem a harmonia ecológica.

No Brasil, a agricultura orgânica é definida pela lei $n^{\circ} 10.831$ de 23 de dezembro de 2003, do Ministério da Agricultura e Abastecimento do Brasil, e estabelece a seguinte conceituação e definição oficial:

"Considera-se sistema orgânico de produção agropecuária todo aquele em que se adotam técnicas específicas, mediante a otimização do uso de recursos naturais e sócio-econômicos disponíveis e o respeito à integridade cultural das comunidades rurais, tendo por objetivo as sustentabilidades econômica e ecológica, a maximização dos benefícios sociais, a minimização da dependência de energia não-renovável, empregando sempre que possível, métodos culturais, biológicos e mecânicos, em contraposição ao uso de materiais sintéticos, a eliminação do uso de organismos genéticos modificados e radiações ionizantes, em qualquer fase do processo de produção, processamento, armazenamento, distribuição e comercialização, e a proteção ao meio ambiente". O conceito de sistema orgânico de produção agropecuária e industrial, estabelecido pelo Ministério da Agricultura, abrange os denominados: ecológico, biodinâmico, natural, sustentável, regenerativo, biológico, agroecológico e permacultura.

Ainda, de acordo com a lei $\mathrm{n}^{\circ}$ 10.831: "Considera-se produto da agricultura orgânica ou produto orgânico, seja ele in natura ou processado, aquele obtido em sistema orgânico de produção agropecuária ou oriundo de processo extrativista sustentável e não prejudicial ao ecossistema local". A mesma lei regulamenta que, para ser comercializado, os produtos orgânicos deverão ser certificados por organismos reconhecidos oficialmente, segundo critérios estabelecidos em regulamento.

Os primeiros movimentos contrários à agricultura convencional guardam pouca ligação com a agricultura orgânica praticada hoje, pois, inicialmente, não havia padrões, regulamentos ou interesse em questões ambientais e de segurança alimentar. Até o início dos anos 70, a produção orgânica no Brasil 
estava diretamente relacionada com movimentos filosóficos, que pregavam o retorno da ligação com a terra como forma alternativa de vida, em contraste com os preceitos da sociedade moderna. Associando a esse fator a recusa do uso do pacote tecnológico da agricultura moderna, que pregava uso intensivo de agroquímicos e movimentação excessiva do solo, acrescentou se a vertente ecológica ao movimento (Ormond, 2002).

A partir da década de 80, com a expansão do consumo de produtos orgânicos, devido à busca por uma alimentação cada vez mais saudável, iniciou-se a comercialização por meio de cooperativas de consumo e lojas especialzadas. Na década de 90, impulsionados por movimentos a favor da ecologia, como a ECO 92, proliferaram os pontos de comercialização de produtos orgânicos. No final dessa década, iniciou-se a venda desses produtos nas grandes redes varejistas, aumentando as vendas e a produção orgânica no Brasil, assim como acontecerá a alguns anos na Europa.

Apesar das diferentes definições e dos critérios definidos na lei, quando se fala de Agricultura Orgânica, está fazendo-se menção à produção agrícola que está em acordo com a lei e que é regulamentada por um organismo competente, chamado de certificadora. Dessa forma, a Agricultura Orgânica atual se distancia cada vez mais dos conceitos propostos por seus idealizadores, sendo direcionada muito mais pelas necessidades do mercado do que por aspectos ideológicos e filosóficos.

\subsubsection{Certificação}

Em todo o mundo e também no Brasil, com o crescimento da Agricultura Orgânica, houve a necessidade de disciplinar o mercado, estabelecendo normas técnicas para a produção, a industrialização e o comércio de alimentos orgânicos e insumos naturais (Paschoal, 1994). Os países da comunidade Européia e Japão exigem que os produtos orgânicos importados sejam certificados por entidades reconhecidas pelos órgãos fiscalizadores em seu 
país de origem, e que essas entidades estejam credenciadas pela IFOAM. A certificação orgânica surgiu nos Estados Unidos como uma ferramenta de marketing, durante os anos de 70 e 80, para assegurar que os alimentos orgânicos atendessem a padrões específicos de produção.

O produto orgânico não difere em cor, forma ou qualquer outro aspecto visual do produto convencional (Souza, 2000). O consumidor é levado a preferilo em função das vantagens nutricionais, ausência de toxicidade e a garantia de que foram produzidos sobre normas rígidas, sendo identificados com o selo de certificação. As certificadoras caracterizam-se por ser um terceiro elemento, além do consumidor e do produtor, que assegura a veracidade do processo de qualidade orgânica. No Brasil, de acordo com Peña (1996), a AAO (Associação de Agricultura Orgânica) e o IBD (Instituto Biodinâmico) são as certificadoras mais antigas e tradicionais. Atualmente, no Brasil, existem 19 certificadoras em operação, sendo 12 nacionais e sete estrangeiras.

O Colegiado Nacional de Agricultura Orgânica, coordenado pelo MAPA (Ministério da Agricultura Pecuária e Abastecimento) tem como atribuição o credenciamento das instituições certificadoras, além da coordenação, supervisão e fiscalização das atividades dos colegiados estaduais e do Distrito Federal. Atualmente, no Brasil, todas as certificadoras estão em processo de regularização.

\subsection{Mercado e comercialização}

\subsubsection{Mercado mundial}

O comércio mundial de produtos orgânicos movimentou no ano de 2003 valores entre US\$23 e 25 bilhões, envolvendo 16 países europeus, América do Norte e Japão. Acredita-se que esses valores possam chegar a US $\$ 30$ bilhões em 2005, segundo o ITC (International Trade Center), citado por Ormond 
(2002). No mundo, a área utilizada para cultivo orgânico atinge quase 23 milhões de hectares e 400 mil propriedades.

No cenário mundial destacam-se como pólos centrais de importação os Estados Unidos, a Alemanha, o Japão e o Reino Unido, com importância crescente para a Alemanha que está se tornando o entreposto de produtos orgânicos na Europa (Ormond, 2002). O continente europeu destaca-se como maior consumidor mundial, tendo movimentado em 1997, US\$6,2 bilhões, sendo US\$ 1,8 bilhão apenas na Alemanha, seguida pelos Estados Unidos (US\$ 4,2 bilhões) e pelo Japão (US\$ 1,2 bilhão) (Ormond, 2002). Com crescimentos a taxas anuais de $22,5 \%$ ao ano, espera-se que, em 2005, os produtos orgânicos na Europa, Estados Unidos e Japão alcancem 15 \% do consumo de alimentos (Ormond, 2002).

A Austrália e a Argentina, devido à tradição pecuária, detêm as maiores áreas sob manejo orgânico no mundo, porém possuem pequeno número de propriedades rurais sob esse sistema de manejo. Na Europa predominam pequenas propriedades, com exceção do Reino Unido, que explora extensas áreas com pecuária. Suíça, Áustria e Dinamarca apresentam as maiores correlações entre o percentual da área e de produtores orgânicos em relação ao total (Tabela 1). A Itália com mais de $6 \%$ da sua área agrícola cultivada organicamente, possui o maior número de produtores dedicados a esta atividade. Estados Unidos e Canadá têm nos grãos e cereais a maior concentração de produtos sob o manejo orgânico.

Tabela 1. Agricultura orgânica no mundo

\begin{tabular}{|c|c|c|c|c|c|c|c|c|}
\hline & \multirow{2}{*}{$\begin{array}{c}\text { Mil ha } \\
\text { manejo } \\
\text { orgânico } \\
\text { certificado } \\
\text { e em } \\
\text { conversão }\end{array}$} & \multirow{2}{*}{$\begin{array}{c}\text { Mil ha de } \\
\text { área total } \\
\text { destinada } \\
\text { à } \\
\text { agricultura }\end{array}$} & \multirow{2}{*}{$\begin{array}{c}\begin{array}{c}\text { Área de } \\
\text { cultura } \\
\text { orgânica }\end{array} \\
\begin{array}{c}\text { Área total } \\
\text { de } \\
\text { Agricultura }\end{array}\end{array}$} & \multirow{2}{*}{$\begin{array}{c}\text { Número de } \\
\text { propriedades } \\
\text { rurais } \\
\text { produtoras } \\
\text { de orgânicos }\end{array}$} & \multirow{2}{*}{$\begin{array}{c}\text { Número total } \\
\text { de } \\
\text { propriedades } \\
\text { rurais } \\
\text { (x 1000) }\end{array}$} & \multirow{2}{*}{$\begin{array}{c}\text { Número } \\
\text { propriedades } \\
\text { com manejo } \\
\text { orgânico } \\
\begin{array}{c}\text { Número total } \\
\text { de } \\
\text { propriedades }\end{array}\end{array}$} & \multicolumn{2}{|c|}{ Área média } \\
\hline & & & & & & & Orgânica & Total \\
\hline Alemanha & 452 & 17160 & 2,63 & 10400 & 534 & 1,95 & 43,5 & 32,1 \\
\hline Áustria & 290 & 3415 & 8,49 & 18360 & 270 & 6,8 & 15,8 & 12,6 \\
\hline Bélgica & 20 & 1383 & 1,45 & 628 & 67 & 0,94 & 31,8 & 20,6 \\
\hline Dinamarca & 165 & 2689 & 6,14 & 3466 & 63 & 5,5 & 47,6 & 42,7 \\
\hline Espanha & 380 & 25630 & 1,48 & 13424 & 1208 & 1,11 & 28,3 & 21,2 \\
\hline
\end{tabular}


Tabela 1. Agricultura orgânica no mundo.

\begin{tabular}{|c|c|c|c|c|c|c|c|c|}
\hline & \multirow{2}{*}{$\begin{array}{l}\text { Mil ha } \\
\text { manejo } \\
\text { orgânico } \\
\text { certificado } \\
\text { e em } \\
\text { conversão }\end{array}$} & \multirow{2}{*}{$\begin{array}{c}\text { Mil ha de } \\
\text { área total } \\
\text { destinada } \\
\text { à } \\
\text { agricultura }\end{array}$} & \multirow{2}{*}{ 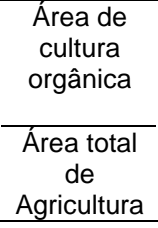 } & \multirow{2}{*}{$\begin{array}{l}\text { Número de } \\
\text { propriedades } \\
\text { rurais } \\
\text { produtoras } \\
\text { de orgânicos }\end{array}$} & \multirow{2}{*}{$\begin{array}{c}\text { Número total } \\
\text { de } \\
\text { propriedades } \\
\text { rurais } \\
(\times 1000)\end{array}$} & \multirow{2}{*}{$\begin{array}{c}\text { Número } \\
\text { propriedades } \\
\text { com manejo } \\
\text { orgânico } \\
\begin{array}{c}\text { Número total } \\
\text { de } \\
\text { propriedades }\end{array}\end{array}$} & \multicolumn{2}{|c|}{ Área média } \\
\hline & & & & & & & Orgânica & Total \\
\hline França & 370 & 28331 & 1,31 & 9260 & 680 & 1,36 & 40,0 & 41,7 \\
\hline Grécia & 25 & 3499 & 0,71 & 5270 & 821 & 0,64 & 4,7 & 4,3 \\
\hline Holanda & 28 & 2000 & 1,40 & 1391 & 94 & 1,48 & 20,1 & 21,3 \\
\hline Irlanda & 32 & 4342 & 0,74 & 1014 & 148 & 0,69 & 31,6 & 29,3 \\
\hline Itália & 959 & 14833 & 6,47 & 49018 & 2135 & 2,30 & 19,6 & 6,9 \\
\hline Portugal & 50 & 3822 & 1,31 & 763 & 417 & 0,18 & 65,5 & 9,2 \\
\hline Suécia & 172 & 2747 & 6,26 & 3329 & 90 & 3,70 & 51,7 & 30,5 \\
\hline Suíça & 95 & 1071 & 8,87 & 5852 & 74 & 7,91 & 16,2 & 14,5 \\
\hline R. Unido & 425 & 18500 & 2,30 & 2975 & 233 & 1,28 & 142,9 & 79,4 \\
\hline Europa & 3463 & 129422 & 2,68 & 125150 & 6834 & 1,83 & 27,7 & 18,9 \\
\hline Canadá & 1000 & 74627 & 1,34 & 1830 & 262 & 0,70 & 546,4 & 284,8 \\
\hline EUA & 900 & 450000 & 0,20 & 5000 & 2191 & 0,23 & 180,0 & 205,4 \\
\hline México & 85 & 108300 & 0,08 & 28000 & 4400 & 0,64 & 3,0 & 24,6 \\
\hline Nafta & 1985 & 632927 & 0,08 & 34830 & 6853 & 0,64 & 57,0 & 92,4 \\
\hline Argentina & 3000 & 169492 & 1,77 & 1400 & 1320 & 0,11 & 2142,9 & 128,4 \\
\hline Brasil & 270 & 353611 & 0,08 & 7063 & 4860 & 0,15 & 38,2 & 72,8 \\
\hline Mercosul & 3270 & 523103 & 0,63 & 8463 & 6180 & 0,14 & 386,4 & 84,6 \\
\hline Austrália & 7654 & 472000 & 1,62 & 1687 & 118,35 & 1,40 & 4537,0 & 3987,9 \\
\hline
\end{tabular}

Fonte: Ormond, 2002.

\subsubsection{Mercado brasileiro}

No Brasil, não existem dados estatísticos oficiais disponíveis sobre Agricultura Orgânica. No entanto, acredita-se que existam cerca de 270 mil hectares em manejo orgânico e 7.063 produtores, sendo 6.936 na produção agropecuária e 127 no processamento. Verifica-se, pela relação entre processadores e produtores, que, no Brasil, a Agricultura Orgânica mantém uma forte predominância do setor primário, evidenciando o estágio inicial de desenvolvimento desse setor (Ormond, 2002).

Do total da área, cerca de 117 mil hectares são destinadas para pecuária e ao redor de 153 mil hectares para outros tipos de exploração agrícola. As culturas da soja, destinada a exportação, e de hortaliças, praticadas em propriedades com gestão familiar, são as que possuem maior número de 
produtores, porém, em relação a área, destacam-se as frutas e a cana-deaçúcar (Tabela 2).

Tabela 2 Culturas com maiores áreas de produção sob manejo orgânico e número de produtores

\begin{tabular}{|c|c|c|c|c|c|}
\hline Produto & $\begin{array}{l}\text { Número de } \\
\text { produtores }\end{array}$ & $\%$ & Produto & $\begin{array}{c}\text { Área } \\
\text { (ha) }\end{array}$ & $\%$ \\
\hline Soja & 593 & 8,40 & Frutas & 30364 & 11,26 \\
\hline Hortaliças & 549 & 7,77 & Cana-de-açúcar & 30193 & 11,19 \\
\hline Café & 419 & 5,93 & Palmito & 20816 & 7,72 \\
\hline Frutas & 273 & 3,87 & Café & 13005 & 4,82 \\
\hline Palmito & 40 & 0,57 & Soja & 12516 & 4,64 \\
\hline Cana-de açúcar & 18 & 0,25 & Hortaliças & 2989 & 1,11 \\
\hline Milho & 6 & 0,08 & Milho & 264 & 0,10 \\
\hline Processados & 127 & 1,8 & Processados & --- & --- \\
\hline Outros+Pasto & 5038 & 71,33 & Outros+Pasto & 159571 & 59,16 \\
\hline Total & 7063 & 100,00 & Total & 269718 & 100,00 \\
\hline
\end{tabular}

Estima-se que o valor de mercado da produção brasileira de produtos orgânicos esteja entre US\$220 milhões e US\$ 300 milhões, sendo a variação devida à margem de lucro aplicada pelos distribuidores e ao desempenho da produtividade de certos produtos, como as frutas e o palmito. No Brasil, a Agricultura Orgânica está concentrada na região Sudeste, que representa 60\% da produção nacional, seguida pelo Sul (25\%), Nordeste (8,6\%), Centro-Oeste $(3,3 \%)$ e o Norte, com apenas $2,6 \%$ desse mercado. O Brasil exportou, em 2004, aproximadamente US\$115 milhões, principalmente de soja e café, sendo responsável ainda por $60 \%$ do fornecimento mundial de açúcar orgânico (Kiss, 2004).

\subsection{Tomaticultura orgânica}

\subsubsection{Aspectos gerais}


Espécie de origem andina, o tomate é denominado botanicamente de Lycopersicon esculentum Mill., sendo uma solanácea herbácea de ampla capacidade adaptativa. O tomate é consumido nas formas in natura e industrializado, por todos os povos e seus frutos possuem alto valor nutritivo (CATI, 1997).

O Brasil é um dos principais produtores mundiais e o estado de São Paulo contribui com cerca de 40\% dessa produção (FNP, 2001). O consumo per capita no estado é de $5,3 \mathrm{~kg}$ por ano, representando $49 \%$ das hortaliças de fruto consumidas (IBGE, 1998). Produtividades médias em sistema convencional de tomate para mesa atingem de 6 a $8 \mathrm{~kg}$ por planta, dependendo do potencial produtivo do cultivar.

A cultura do tomate exige cuidados constantes, pois está sujeita ao ataque de grande número de doenças, pragas e desordens fisiológicas. O produtor que paga atualmente entre $R \$ 24$ mil e $R \$ 33$ mil por $500 \mathrm{~g}$ de sementes de um híbrido longa vida para implantar uma lavoura de 150 mil pés de tomate, mesmo lançando mão de todo arsenal de agroquímicos à sua disposição, não consegue vencer a batalha contra as pragas e as doenças que atacam a cultura durante todo o seu ciclo e que lhe causa, freqüentemente, grandes prejuízos. É importante destacar que os defensivos agrícolas respondem hoje por mais de $35 \%$ do custo total de uma lavoura de um hectare de tomate estaqueado (Melo, 2003).

O alto potencial destruidor de pragas como a broca-pequena-dos-frutos (Neoleucinodes elegantalis), traça-do-tomateiro (Tuta absoluta) e mosca-branca (Bemisia argentifolii), cujo dano mais importante decorre de sua eficiente transmissão de geminiviroses, têm causado preocupação entre os produtores de tomate de mesa, nos últimos anos. Na ausência de métodos alternativos de controle, o uso de inseticidas torna-se, via de regra, desmedido e com aplicação incorreta. Por conta disso, as pragas desenvolvem resistência contra os inseticidas, os inimigos naturais são eliminados e os resíduos tóxicos causam sérios impactos à saúde pública e ao meio ambiente. Outro fator desfavorável 
tem a ver com a implantação de lavouras em áreas concentradas, extensas e com objetivo de produção durante o ano todo. Em conseqüência, a população de pragas mantém-se em níveis sempre elevados (Melo, 2003).

A composição do tomate varia conforme o cultivar, as condições de cultivo, ambientais e nutricionais da planta. De acordo com Alvarenga et al. (2004), o fruto fresco apresenta baixo poder calórico, baixo teor de matéria seca e altos índices de cálcio e vitamina C. Quanto à quantidade de sólidos solúveis, esses acumulam-se no final da fase de maturação, sendo constituído por cerca de $65 \%$ de açúcares. Portanto, uma colheita antes da maturidade fisiológica, acompanhada de uma baixa luminosidade e eliminação de folhas vai ocasionar diminuição do teor de açúcares no fruto.

Quanto ao teor de sais minerais no fruto, o potássio é encontrado em maior quantidade, o qual, por sua vez, tem influência na qualidade do fruto (Alvarenga et al., 2004). O tomate, caracterizado pelo seu baixo valor energético, é recomendado aos indivíduos que desejam se submeter a uma dieta hipocalórica ou que necessitam de um alimento de fácil digestão (Minami, 1989).

\subsubsection{Manejo orgânico}

Em experimento com tomate orgânico, conduzido na Turquia, testando em ambiente protegido o efeito de diferentes tipos e composições de adubação orgânica no outono e na primavera, Tuzel (2004) reportou produtividades de 3 a $4,5 \mathrm{~kg}$ por planta e de 6,5 a 8,5 kg por planta, respectivamente.

Bettiol (2004) avaliou o desempenho da produção orgânica de tomate em propriedades da região de Campinas, observou produtividades de $4 \mathrm{~kg}$ por planta, similares ao descrito por Tuzel (2004), na Turquia, no ensaio de outono, o que representa $65 \%$ dos valores alcançados por produções convencionais no Brasil. 
Bettiol et al. (2004), em estudo comparando sistemas de produção orgânico e convencional com os cultivares Débora e Santa Clara, concluíram que, em média, a produtividade do tomate orgânico corresponde a 36,5\% da produção convencional. No cultivar Santa Clara, as colheitas foram 23,5\% da produção convencional e, no cultivar híbrido Débora, 51,5\%, valores estes abaixo dos obtidos por Tuzel (2004) e Bettiol (2004). Conforme descrito no trabalho, a pesquisa foi realizada em área experimental que certamente não possuía as características desejáveis para o cultivo orgânico, fato comprovado pela análise de solo apresentada e pela adubação orgânica utilizada. Tratandose de pesquisa em agricultura orgânica é preciso ter um cuidado especial na implantação e desenvolvimento do projeto, porque o sistema orgânico, por definição, exige um manejo de solo e um ambiente equilibrado, fatores que não só auxiliam no controle de pragas e doenças, mas também promovem maior produtividade. Os mesmos autores também concluíram que a septoriose (Septoria lycopersici) ocorreu durante todo o ciclo da cultura com maior incidência no cultivo orgânico, não ocorrendo diferenças significativas entre os cultivares testados. A pinta preta (Alternaria solani) teve menor incidência no sistema orgânico. Normalmente, doenças radiculares parecem ocorrer em menor intensidade no sistema orgânico, enquanto que as doenças foliares não seguem um padrão específico (Van Bruggen, citado por Bettiol et al., 2004).

A adubação orgânica do tomateiro, devido à grande exigência nutricional da cultura, é um ponto importante para o sucesso do cultivo, porém, poucos estudos foram dedicados a esse tema. Tuzel (2004), após testar quatro combinações de adubos orgânicos, incluindo esterco de galinha compostado, esterco de gado, E 2001 e Allgrow Bioplasma concluiu que a melhor resposta foi obtida utilizando-se esterco de galinha compostado. Tal estudo foi desenvolvido em região de clima frio, onde a decomposição da matéria orgânica é lenta, ocorrendo acúmulo no solo. Provavelmente, esses resultados não se reproduziriam em climas tropicais, pois o esterco de galinha, em climas quentes e úmidos, apresenta máxima decomposição e conseqüente liberação de nutrientes 
nos primeiros 30 dias depois de aplicado ao solo. Por sua parte, o tomateiro apresenta ciclo de produção que pode atingir até 180 dias, sendo a maior exigência nutricional por volta dos 80-100 dias, durante o período de florescimento e enchimento de frutos. Outro ponto discutível é quanto aos nutrientes contidos no esterco. É sabido, que o esterco de galinha apresenta alta concentração de nitrogênio, porém o tomateiro é uma cultura com maior exigência de potássio (Alvarenga et al., 2004), nutriente este com baixa concentração em resíduos animais.

\subsubsection{Cultivares de polinização livre (PL) versus híbridos}

No processo de seleção de cultivares, a adaptação e as características dos produtos são fatores importantes que definem a viabilidade ou não de seu cultivo. Primavesi (2001) comentou que, em cultivos ecológicos, as variedades devem ser compatíveis ao sistema de produção adotado, e que híbridos não possuem tais características. Bettiol (2004) fortaleceu a mesma idéia e completou que o ideal seria o uso de cultivares mais rústicos como as variedades Rio Grande, Santa Cruz e Santa Clara, pois os híbridos, quando utilizados na agricultura orgânica, produzem até $40 \%$ menos do que cultivados na agricultura convencional. Resultados totalmente opostos foram obtidos pelo mesmo autor e colaboradores (Bettiol et al., 2004) que, comparando o cultivar de polinização livre Santa Clara e o híbrido Débora dentro do sistema orgânico, obtiveram maiores produções com o uso do híbrido.

Nesse mesmo estudo, os autores concluíram que os dois cultivares testados tiveram melhor desenvolvimento no cultivo convencional, e que o híbrido Débora apresentou melhor desenvolvimento e maior produção que o cultivar Santa Clara, em ambos os sistemas, porém mais acentuada no cultivo orgânico. Bettiol et al. (2004) atribuíram essa diferença entre a produtividade alcançada pelos cultivares testados, à maior suscetibilidade do "Santa Clara" ao vira-cabeça, dados perfeitamente coerentes com os relatados por Nagai (1993), 
que citou esse cultivar como sendo $100 \%$ suscetível ao vira-cabeça. O mesmo autor concluiu que o "Santa Clara" apresenta, também, suscetibilidade às principais doenças do tomate.

Certamente, os resultados distintos obtidos entre as variedades testadas por Bettiol et al. (2004) devem-se a grande suscetibilidade do "Santa Clara" às principais pragas e doenças do tomate, fato que não ocorre com o híbrido Débora, que possui resistência genética a inúmeras doenças incorporadas durante o processo de melhoramento.

Os problemas fitossanitários são o ponto mais importante na produção de tomate orgânico. O uso de cultivares tolerantes ou resistentes pode propiciar aos produtores uma grande vantagem no manejo de pragas e doenças limitantes (Diver et al., 1999).

\subsubsection{Sistemas de condução}

No cultivo de tomate, vários tipos de poda são indicados durante o ciclo da cultura para melhorar o aspecto e a qualidade comercial dos frutos, permitir o tutoramento, aumentar o tamanho dos frutos e facilitar os tratos culturais (Campos et al., 1987). Entre os cultivares de tomate mais utilizados no Brasil para produção de frutos para consumo in natura, destaca-se os de hábito de crescimento indeterminado, que possuem a característica de emitir ramificações laterais a partir de gemas axilares do caule principal. A poda de condução consiste na retirada das brotações axilares, quando tenras, conduzindo a planta com um número de hastes variando entre um e quatro (Filgueira, 1982). Segundo Oliveira et al. (1995a), o rendimento comercial do tomate depende mais do número de hastes do que do número de plantas por hectare. Em outros estudos, Oliveira et al. (1995b), concluíram que plantas com duas hastes apresentaram produções superiores as plantas com apenas um ramo, conforme relatado também por Carvalho (2002). 
Outro tipo de poda adotada é a poda apical de desponta, que consiste na remoção da gema apical, deixando duas ou três folhas acima do sétimo ou oitavo racemo. Essa prática vem sendo utilizada, para controlar a altura da planta, o número de cachos por planta e o tamanho dos frutos (Logendra et. al, 2001). Conforme recomendações da EMBRAPA (1975), a poda apical deve ser realizada sempre após a sétima inflorescência.

Segundo Gusmão (1988) a poda apical antecipa a colheita, e quando realizada até o quarto racemo, permite obter $90 \%$ da produção total nas primeiras cinco semanas de colheita. Streck et al. (1998) descreveram dados semelhantes, obtendo em plantas com três inflorescências 80 \% da produção nas primeiras cinco semanas, contra sete semanas do sistema de condução convencional, com sete racemos.

Gusmão (1988), ainda relatou que, plantas conduzidas com apenas uma haste e com poda apical acima do quarto racemo, independente do número de haste por hectare, necessitam de metade do volume de defensivos aplicados num sistema em que a planta é conduzida com duas hastes sem poda apical.

Silva Junior et al. (1992) recomendam a poda apical drástica, realizada acima da terceira inflorescência, como mecanismo de escape contra a alta incidência de pragas e doenças, e pela redução do ciclo da cultura. Resultados similares são sugeridos por Belfort et al. (1982), que indicam para condições adversas a exploração do tomateiro, a poda apical acima do terceiro racemo em uma densidade de 40 mil plantas por hectare. Normalmente, essa prática está associada a maior densidade de plantas, para que não ocorra comprometimento da produtividade por área.

Streck et al. (1998), por sua vez, não observaram diferenças quanto a produtividade de frutos comercializáveis, para plantas conduzidas até a terceira inflorescências na densidade de 80 a 100 mil plantas por hectare, quando comparado ao sistema convencional de condução com sete racemos por planta e 40 mil plantas por hectare. 
Por sua vez, Poerschke et al. (1995), estudando sistemas de condução com uma e duas hastes por planta e poda no $3^{\circ}, 5^{\circ}$ e $7^{\circ}$ racemo, observaram em estufa, que plantas com duas hastes apresentaram maior rendimento de frutos comerciais, e que plantas conduzidas com uma haste e poda apical acima do terceiro racemo, alcançaram maior massa média de frutos.

Os efeitos mais visíveis de uma alta densidade de plantas, no cultivo de tomate, são o aumento da produção precoce e o encurtamento do ciclo. Em contrapartida, ocorre uma menor qualidade do fruto, por reduzir o seu tamanho e aumentar o risco de incidência de doenças fúngicas (Nuez, 1995). 


\section{MATERIAIS E MÉTODOS}

\subsection{Local de instalação dos experimentos}

Os experimentos foram conduzidos em ambiente protegido, em propriedades localizadas nos municípios de Ibiúna, SP e Araraquara, SP, ambas certificadas pelo IBD.

O período de condução dos experimentos variou conforme a localidade, ajustando-se às épocas de cultivo dos dois produtores e às peculiaridades climáticas de cada local.

\subsubsection{Experimento I - Ibiúna, SP}

O experimento foi realizado no período de março a outubro de 2004, e instalado na propriedade pertencente ao engenheiro agrônomo Marcelo Akira Saito, localizada a Rodovia Júlio Del Fabbro, km 3, Bairro Rio de Una, Ibiúna, SP. A área cultivada com tomate orgânico na propriedade é de aproximadamente 2,8 ha, e a atividade foi iniciada em 2000.

O município de Ibiúna está localizado em altitude média de $996 \mathrm{~m}$, apresentando uma precipitação anual média em torno de $1200 \mathrm{~mm}$. O clima da região é de montanha (temperado com inverno úmido).

Os dados e informações referentes às características climáticas foram fornecidos por estação meteorológica convencional, situada no Morro de Santana, em São Paulo, SP, pertencente ao INMET. A latitude, longitude e altitude da estação são: $23^{\circ} 30^{\prime} \mathrm{S}, 4^{\circ} 37^{\prime} \mathrm{O}$ e $792,06 \mathrm{~m}$, respectivamente. 
No Anexo A, estão as figuras que representam as temperaturas diárias registradas para o período de maio a setembro de 2004.

A análise de solo da área experimental encontra-se na Tabela 3.

Tabela 3. Resultado da análise de solo da área do experimento I, Ibiúna-SP

\begin{tabular}{llc}
$\mathrm{pH}$ & $\mathrm{CaCl} 2$ & 5,5 \\
$\mathrm{pH}$ & Água & 6,2 \\
$\mathrm{MO}$ & $\%$ & 4,2 \\
$\mathrm{CTC}$ & $\mathrm{mEq} / 100 \mathrm{~mL}$ & 11,4 \\
$\mathrm{~S}$ & $\mathrm{mEq} / 100 \mathrm{~mL}$ & 9,4 \\
$\mathrm{~V} \%$ & & 82,4 \\
\hline
\end{tabular}

\begin{tabular}{llccc}
\hline \multicolumn{1}{c}{ Elementos } & mEq/100mL & ppm & Interpretação \\
\hline Acidez total & $\mathrm{H}+$ & 2,0 & & Baixo \\
Cálcio & $\mathrm{Ca}$ & 7,4 & & Alto \\
Magnésio & $\mathrm{Mg}$ & 1,4 & & Médio \\
Potássio & $\mathrm{K}$ & 0,56 & & Alto \\
Sódio & $\mathrm{Na}$ & & 38,0 & Baixo \\
Relações & $\mathrm{Ca} / \mathrm{Mg}$ & 5,3 & & Médio \\
& $\mathrm{Ca} / \mathrm{K}$ & 13,1 & & Médio \\
& $\mathrm{Mg} / \mathrm{K}$ & 2,5 & & Baixo \\
Alumínio & $\mathrm{Al}$ & ----- & & \\
Nitrogênio & $\mathrm{N} \%$ & 0,21 & & Médio \\
Fósforo & $\mathrm{P}(\mathrm{Melich)}$ & & 69,2 & Alto \\
& $\mathrm{P}(\mathrm{resina})$ & & 97,2 & Alto \\
Ferro & $\mathrm{Fé}$ & & 43,6 & Médio \\
Manganês & $\mathrm{Mn}$ & & 60,5 & Médio \\
Cobre & $\mathrm{Cu}$ & 3,5 & Médio \\
Zinco & $\mathrm{Zn}$ & & 35,9 & Médio \\
Boro & $\mathrm{B}$ & & 0,4 & Médio \\
Enxofre & $\mathrm{S}$ & & 23,2 & Alto \\
\hline
\end{tabular}

O experimento foi instalado em estufa tipo arco com estrutura metálica, conjugada, com dimensões de 51,2 $\mathrm{m} \times 31,5 \mathrm{~m}$ e pé direito de $3,5 \mathrm{~m}$, coberta com polietileno transparente de $75 \mu \mathrm{m}$ (Anexo E, Fig. 3).

O cronograma de manejo realizado no experimento encontra-se no Anexo B. 


\subsubsection{Experimento II - Araraquara, SP}

O experimento foi instalado no período de maio a outubro de 2004, no município de Araraquara, SP, Sítio Oyafuso, de propriedade do técnico agrícola Marcelo Oyafuso. A área da propriedade é de sete hectares, sendo um hectare cultivado com tomate orgânico em estufa. Essa atividade teve início em 1992.

Os dados climáticos do município de Araraquara foram fornecidos pela EMBRAPA Pecuários Sudeste, São Carlos, SP, distante cerca de $70 \mathrm{~km}$ do local onde o experimento foi instalado. Os dados foram coletados em estação meteorológica com latitude de $21^{\circ} 57^{\prime} 42^{\prime \prime} \mathrm{S}$, longitude de $47^{\circ} 50^{\prime} 28^{\prime \prime} \mathrm{W}$ e altitude de 860 m (EMBRAPA, 2004). No Anexo C, estão as figuras que representam as temperaturas diárias registradas para o período de maio a setembro de 2004.

Segundo Köeppen, o clima é classificado como tropical de altitude, Cwa, com clima quente e inverno seco, no qual a temperatura média do mês mais frio é inferior a $18^{\circ} \mathrm{C}$ e a do mês mais quente ultrapassa $22^{\circ} \mathrm{C}$. O total das chuvas do mês mais seco não atinge $30 \mathrm{~mm}$, e o do mês mais chuvoso é dez ou mais vezes maiores do que os do mês mais seco. Segundo Nimer, citado por EMBRAPA (2004), o período seco geralmente é de junho a agosto, podendo se prolongar até novembro.

A análise de solo da área foi realizada em fevereiro de 2002, e analisada pelo Instituto Agronômico (IAC). Os resultados podem ser observados na Tabela 4.

Tabela 4. Resultado da análise de solo da área do experimento II, Araraquara,

\begin{tabular}{|c|c|c|c|c|c|c|c|c|}
\hline \multicolumn{9}{|c|}{ SP } \\
\hline $\begin{array}{c}\text { MO } \\
\text { Matéria orgânica }\end{array}$ & $\operatorname{pH}_{\text {Solução CaCl2 }}^{\mathbf{H}}$ & $\underset{\text { P resina }}{\mathbf{P}}$ & K & $\mathrm{Ca}$ & Mg & $\mathrm{Na}$ & Al & S.B. \\
\hline $\mathrm{g} / \mathrm{dm}^{3}$ & & $\mathrm{mg} / \mathrm{dm}^{3}$ & \multicolumn{6}{|c|}{$\mathrm{mmol}_{/} / \mathrm{dm}^{3}$} \\
\hline 18 & 6,8 & 474 & 2,0 & 69 & 25 & -- & -- & 96,0 \\
\hline 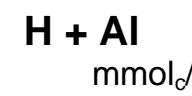 & $\underset{\mathrm{dm}^{3}}{\text { CTC }}$ & $\begin{array}{l}\mathbf{V} \\
\%\end{array}$ & $S$ & B & $\underset{m}{\mathrm{Cu}}$ & $\mathrm{n}^{3} \mathrm{Fe}$ & Mn & $\mathrm{Zn}$ \\
\hline 13 & 109,3 & 88 & -- & 1,02 & 8,4 & 26 & 14,0 & 10,9 \\
\hline
\end{tabular}


O experimento foi instalado em estufa de estrutura lateral de madeira com laterais abertas, com dimensões de 7,0 $\mathrm{m} \times 50,0 \mathrm{~m}$ e pé direito de 3,0 m, coberta com plástico transparente de $75 \mu \mathrm{m}$ (Anexo F, Fig.3). O cronograma de manejo realizado no experimento encontra-se no Anexo D.

\subsection{Manejo orgânico}

\subsubsection{Experimento I - Ibiúna, SP}

$\mathrm{Na}$ área experimental, realizou-se previamente o preparo dos canteiros com o uso de rotoencanteiradeira. Em seguida, foi feita adubação verde com aveia preta (Avena strigosa) (Anexo E, Fig. 1). A aveia preta apresenta boa tolerância ao frio, tem ciclo vegetativo de 140 a 160 dias e produz até oito t/ha/ano de matéria seca (Matsuda, 2004). Ao atingir a fase de florescimento, a aveia foi roçada sendo, posteriormente, recoberta por um plástico preto (Anexo E, Fig. 2). Desse modo, o preparo de solo foi simples, com revolvimento mínimo do mesmo.

As mudas foram produzidas em bandejas de polietileno expandido e a irrigação foi realizada por sistema de microaspersão.

A calagem, gessagem e fosfatagem foram realizadas de acordo com os resultados da análise de solo e com as normas da certificadora.

O transplantio foi realizado 30 dias após o semeio, adotando-se o espaçamento de 1,5 m entre linhas e 0,35 m entre plantas na linha de plantio.

As plantas foram conduzidos no sistema de haste única, com poda apical, acima do terceiro racemo.

O sistema de irrigação adotado pelo produtor foi o de gotejamento. Foram realizadas irrigações diárias, em pulsos de 20 minutos. O número de pulsos diários foi controlado, a fim de se evitar abortamento de flores, fundo preto e promover bom enchimento de frutos. Para prevenir o excesso de 
gutação pela manhã, a intensidade da irrigação foi reduzida até o nível de pouca ou nenhuma gutação.

A adubação foi realizada por fertirrigação. O adubo utilizado foi o sulfato duplo de potássio e magnésio (Sul-Po-Mag), aplicado nas seguintes fases de desenvolvimento do tomateiro:

- 30-60 DAT: $150 \mathrm{~kg} / \mathrm{ha}$ (três aplicações semanais com eletrocondutividade de $2,0 \mathrm{mS} / \mathrm{cm})$.

- 60-120 DAT: $450 \mathrm{~kg} / \mathrm{ha}$ (três aplicações semanais com eletrocondutividade de 2,5 $\mathrm{mS} / \mathrm{cm})$.

Os canteiros foram recobertos por plástico preto, visando reduzir a evaporação da água no solo. O uso desse tipo de "mulching" é permitido pela certificadora do produtor.

O monitoramento da traça-do-tomateiro (Tuta absoluta) foi realizado por meio de retiradas periódicas das folhas das plantas que apresentavam galerias resultantes da atividade da lagarta. As folhas foram colocadas em sacos plásticos e descartadas. Outro método adotado para controle da praga foi por meio de armadilhas adesivas, visando capturar os adultos (Anexo E, Fig. 4). As armadilhas possuíam um pequeno recipiente com melaço para atrair os insetos. Foram instaladas também, lâmpadas em diversos postes ao longo do interior das estufas. Com as luzes acesas as mariposas, que é a forma adulta das traças, eram atraídas e capturadas. Foram realizadas, ainda, pulverizações com o produto Bac-Control WP.

Vale destacar que, nessa propriedade, a eliminação dos restos culturais é uma prática rotineira e que contribui para minimizar os ataques da traça-dotomateiro. Outro fator que auxilia na prevenção da ocorrência da praga é a concentração dos plantios apenas no período do verão.

Para o controle da mosca branca (B. argentifolii) foi aplicado o produto Natur'óleo na dosagem de $750 \mathrm{~mL} / \mathrm{ha}$. 
O controle de pragas e doenças e a aplicação de adubos foliares foram realizados por meio de duas pulverizações semanais, de acordo com o seguinte programa:

$1^{\text {a }}$ pulverização: adubo foliar Arbore CaB2 (100 mL) + Bac-Control WP (100 g)

+ Rocksil (100 g) + sulfato de zinco (30 g) + sulfato de manganês (30 g).

$2^{a}$ pulverização: Kumulus $(100 \mathrm{~g})+$ Biocontrol $(100 \mathrm{~mL})+$ CaB2 $(100 \mathrm{~mL})$.

Obs: Vazão de 500 L/ha e doses em g ou mL/100 L de água.

As plantas daninhas foram controladas com o uso de mulching plástico.

As colheitas foram realizadas semanalmente quando os frutos atingiram o estádio de vez (pintado).

\subsubsection{Experimento II - Araraquara, SP}

O preparo de solo da área experimental foi realizado da seguinte maneira: as plantas da cultura anterior, juntamente com o mato que nasceu ao longo do cultivo, foram tombados no próprio canteiro e triturados com auxílio de uma roçadeira (Anexo F, Fig. 1). Posteriormente, fez-se incorporação com rotoencanteiradeira, regulado para operar em baixa rotação, levando-se em consideração o ponto ideal de umidade para o preparo de solo. Em seguida, foi feita aplicação de composto orgânico à base de torta de mamona, farelo de arroz, farinha de concha, farinha de peixe, capim napier triturado, melaço, água e adição de sulfato de zinco e ácido bórico. O composto foi levemente incorporado ao solo, regulando-se o implemento para uma profundidade máxima de incorporação de 10,0 cm. Os canteiros, depois da segunda incorporação, foram cobertos com uma camada de palhada, geralmente de braquiária. Com a palhada disposta na superfície dos canteiros, foi instalado o sistema de irrigação por gotejamento (Anexo F, Fig. 2). 
As mudas foram produzidas em estufas em bandejas de polietileno expandido, com o uso de substrato orgânico confeccionado pelo próprio produtor.

O transplantio das mudas foi realizado 34 dias após o semeio, adotandose espaçamento de 0,80 m entre linhas e 0,60 m entre plantas nas linhas. As plantas foram conduzidas no sistema de haste dupla sem poda apical.

Utilizou-se irrigação por gotejamento, de acordo com o seguinte cronograma:

a) Um dia antes do transplantio das mudas: irrigação dos canteiros;

b) No primeiro dia após o transplante: irrigação por 15 minutos;

c) A cada quatro dias, até o $20^{\circ}$ dia: irrigação por 15 minutos;

d) A partir do $20^{\circ}$ dia: a freqüência e o tempo de irrigação foram aumentados, de acordo com a exigência das plantas. A constante observação e acompanhamento das estufas se tornaram ainda mais importante, para que não houvesse nenhum déficit hídrico no solo;

e) Após o surgimento do primeiro racemo, a freqüência e o tempo das irrigações atingiram valores máximos, sendo feitas diariamente durante uma hora à uma hora e meia.

Para o controle de pragas, o produtor adota métodos alternativos. No controle da traça-do-tomateiro foi adotado controle biológico, com a liberação de ovos de Trichogramma spp.. Na área protegida, em cultivo com tomate, foram colocadas cartelas com 40 mil ovos do parasitóide.

A broca-pequena-do-fruto ( $N$. elegantis) e a broca-grande-do-fruto (Helicoverpa zeae) foram controladas pela pulverização com Bacillus thurigiensis var. kurstaki, linhagem HD-1 (DiPel ${ }^{\circledR} \mathrm{PM}$ ). No preparo da calda, foram utilizados $80 \mathrm{~g}$ do produto em 100 litros de água e aplicados de 600 a 800 litros de calda por hectare. As pulverizações foram realizadas de manhã ou ao entardecer. As aplicações foram feitas no estágio de maior atividade larval, determinado pela contagem ou levantamento de pragas, ao se detectar as primeiras infestações na cultura. 
Para o controle do ácaro do bronzeamento ou micro-ácaro, foi realizada a aplicação de produto à base de enxofre $\left(\right.$ KUMULUS $\left.^{\circledR}\right)$ a 0,3 \%.

A colheita do experimento foi realizada duas vezes por semana.

\subsection{Cultivares avaliados}

Foram estudados 11 cultivares de tomate de hábito de crescimento indeterminado, pertencentes a diferentes segmentos de mercado, sendo oito híbridos $(H)$ e três cultivares de polinização livre $(P L)$ (Anexo $G$ ).

Os híbridos Saladete DRW 3410 e Jane foram adotados como cultivarespadrão para os experimentos I e II, respectivamente, por serem produzidos em escala comercial sob sistema orgânico nas áreas onde os experimentos foram instalados.

A descrição das características dos cultivares testadas foi obtida em catálogos das empresas de sementes e de institutos públicos de pesquisa detentores dos seus direitos autorais (Tabela 5)

Tabela 5. Descrição dos cultivares de tomate testados nos experimentos I e II, conduzidos em Ibiúna, SP e Araraquara, SP, 2004

\begin{tabular}{|c|c|c|}
\hline Tratamentos/Cultivares & Descrição varietal & $\begin{array}{c}\text { Resistência a } \\
\text { doenças* }\end{array}$ \\
\hline Avalon & $\begin{array}{l}\text { Híbrido } F_{1} \text { do grupo Santa Clara } \\
\text { desenvolvida pela empresa Hortivale } \\
\text { Sementes do Vale Ltda.; produz fruto } \\
\text { firme, grande (170-200g), trilocular, } \\
\text { ombro de cor uniforme e boa } \\
\text { conservação pós-colheita (longa vida } \\
\text { estrutural) }\end{array}$ & V1, Fol 1-2, Tm \\
\hline Colibri & $\begin{array}{l}\text { Híbrido } F_{1} \text { com planta vigorosa, com } \\
\text { ampla capacidade de adaptação, } \\
\text { inclusive sob temperatura elevada. } \\
\text { Possui fruto com formato intermediário } \\
\text { entre o tipo Santa Cruz e o Saladete; tem } \\
\text { boa firmeza e peso médio variando de } \\
180 \text { a } 200 \mathrm{~g} \text {. }\end{array}$ & $\begin{array}{l}\text { Tm, Fol 1-2, V1, } \\
\text { St, N }\end{array}$ \\
\hline
\end{tabular}


Tabela 5. Descrição dos cultivares de tomate testados nos experimentos I e II, conduzidos em Ibiúna, SP e Araraquara, SP, 2004.

\begin{tabular}{|c|c|c|}
\hline Tratamentos/Cultivares & Descrição varietal & $\begin{array}{c}\text { Resistência a } \\
\text { doenças* }\end{array}$ \\
\hline HTX - 5415 & $\begin{array}{l}\text { Cultivar comum (PA), tipicamente } \\
\text { saladete, com frutos de alta firmeza } \\
\text { (longa vida estrutural), biloculares e } \\
\text { cicatriz peduncular pequena. É uma } \\
\text { cultivar experimental da empresa } \\
\text { Hortivale Sementes do Vale Ltda. }\end{array}$ & V1, Fol 1-2 \\
\hline HTX - 8027 & $\begin{array}{l}\text { Híbrido } F_{1} \text { do tipo Santa Cruz, vigoroso e } \\
\text { com frutos predominantemente } \\
\text { triloculares, de elevada firmeza (longa } \\
\text { vida estrutural) e cor dos ombros } \\
\text { uniforme. }\end{array}$ & V1, Fol-1, N \\
\hline Sahel & $\begin{array}{l}\text { Híbrido } F_{1} \text { do tipo saladete, com alto } \\
\text { potencial produtivo e muito uniforme. } \\
\text { Possui frutos grandes, alongados e muito } \\
\text { firmes. }\end{array}$ & $\begin{array}{l}\text { V1, Fol 1-2, Fr, } \\
\text { St, Tm, N; }\end{array}$ \\
\hline San Marzano & $\begin{array}{l}\text { Cultivar comum (PA) de origem italiana } \\
\text { com plantas vigorosas e frutos } \\
\text { tipicamente alongados, de baixa } \\
\text { consistência e ocos. Destaca-se pelo } \\
\text { excelente sabor. A colheita se inicia de } \\
100 \text { a } 110 \text { dias após a semeadura. }\end{array}$ & \\
\hline San Vito & $\begin{array}{l}\text { Híbrido } F_{1} \text { do tipo italiano desenvolvido } \\
\text { pela Embrapa Hortaliças; apresenta bom } \\
\text { pegamento de frutos, inclusive nos } \\
\text { racemos superiores. Os frutos } \\
\text { apresentam boa firmeza, formato } \\
\text { alongado, sabor diferenciado, peso médio } \\
\text { de } 100 \mathrm{~g} \text {, sólidos solúveis em torno de } \\
4,8^{\circ} \text { Brix e acidez de } 56,61 \text { (ácido cítrico). } \\
\text { Destaca-se, ainda, pela elevada } \\
\text { concentração de licopeno. A colheita se } \\
\text { inicia } 80 \text { dias após o transplante. }\end{array}$ & $\begin{array}{l}\text { Bsp, St, Fol 1-2, } \\
\text { V1, N; pulgão } \\
\text { das solanáceas } \\
\text { (Macrosiphum } \\
\text { euphorbiae) }\end{array}$ \\
\hline Júpiter & $\begin{array}{l}\text { Híbrido } F_{1} \text { do tipo saladete, com frutos } \\
\text { alongados de bom sabor, boa coloração e } \\
\text { consistência extra-firme, resultando numa } \\
\text { boa durabilidade pós-colheita. A planta é } \\
\text { produtiva e vigorosa. Inicia-se a colheita } \\
\text { em torno de } 100 \text { dias após o transplante. }\end{array}$ & Tm, V1, Fol 1-2 \\
\hline Raminho Sel. IPA & $\begin{array}{l}\text { Cultivar comum (PA) com planta } \\
\text { vigorosa, selecionado pela Empresa } \\
\text { Pernambucana de } \\
\text { Agropecuária (IPA), a partir de uma } \\
\text { população local do tipo Santa Cruz. } \\
\text { Possui uma boa uniformidade de } \\
\text { frutificação e os frutos são firmes, } \\
\text { biloculares e com ombros uniformes. }\end{array}$ & St \\
\hline
\end{tabular}


Tabela 5. Descrição dos cultivares de tomate testados nos experimentos I e II, conduzidos em Ibiúna, SP e Araraquara, SP, 2004.

\begin{tabular}{|c|c|c|}
\hline Tratamentos/Cultivares & Descrição varietal & $\begin{array}{c}\text { Resistência a } \\
\text { doenças** }\end{array}$ \\
\hline Saladete DRW 3410 & $\begin{array}{l}\text { Híbrido } F_{1} \text { do tipo italiano altamente } \\
\text { produtivo, precoce e com cachos } \\
\text { uniformes, possui ótimo sabor; os frutos } \\
\text { são firmes e uniformemente coloridos. }\end{array}$ & $\begin{array}{l}\text { Tm, V1, Fol 1-2, } \\
\mathrm{N}\end{array}$ \\
\hline Jane & $\begin{array}{l}\text { Híbrido } F_{1} \text { tipo caqui com alto potencial } \\
\text { produtivo; produz frutos com peso médio } \\
\text { de } 290 \mathrm{~g} \text {. }\end{array}$ & $\begin{array}{l}\text { Tm, V1, Fol 1-2, } \\
\text { Sw }\end{array}$ \\
\hline
\end{tabular}

V1: murcha-de-verticílio (Verticillium dahliae); Fol-1: murcha-de-fusário raça 1 (Fusarium oxysporum f.sp. Iycopersici); Fol 1-2: murcha-de-fusário raças 1 e 2 (Fusarium oxysporum f.sp. lycopersici); St: mancha-de-estenfílio (Stemphylium solani e S. lycopersici), Fr: Fusarium oxysporum radicis lycopersici; Tm: ToMv (vírus do mosaico do tomate); Sw: vírus do viracabeça-do-tomateiro (Tospovírus); N: nematóide-de-galhas (Meloidogyne spp.) e Bsp: pintabacteriana (Pseudomonas syringae pv. tomato).

\subsection{Delineamento experimental}

A análise estatística dos dados foi realizada separadamente, devido à adoção de manejo cultural diferenciado nas propriedades onde os experimentos foram conduzidos.

Os dez e oito cultivares estudados nos experimentos I (Avalon, Colibri, HTX - 5415, HTX - 8027, Sahel, San Marzano, San Vito, Júpiter, Raminho e Saladete DRW 3410) e II (Avalon, Colibri, HTX - 5415, HTX - 8027, Sahel, San Marzano, San Vito e Jane), foram distribuídos num delineamento de blocos ao acaso com cinco (experimento I) e quatro (experimento II) repetições.

A unidade experimental (parcela), no experimento I, foi constituída por um canteiro abrangendo área total de $6,3 \mathrm{~m}^{2}$, com uma fileira central de 12 plantas sendo oito úteis, espaçadas $1,5 \mathrm{~m}$ entre linhas e 0,35 $\mathrm{m}$ entre plantas na linha. Com esse espaçamento a densidade é de 20.000 plantas por hectare.

A parcela do experimento II foi constituída por um canteiro com área total de $5,4 \mathrm{~m}^{2}$, com 12 plantas dispostas em fileiras duplas (seis plantas de cada lado), no espaçamento de 0,80 m entre plantas e 0,60 m entre plantas da 
mesma fileira. A população de plantas nesse espaçamento é de 20.000 plantas por hectare.

Os dados foram coletados em oito plantas da parcela, consideradas úteis.

Os dados referentes a produção total (PT) e comercial de frutos por planta (PC) no experimento I, foram transformados em $\sqrt{x}$. No experimento II, os dados de PC foram transformados em log $x$. Houve necessidade de transformação dos dados desses caracteres porque as pressuposições do modelo matemático foram violadas.

Obtendo-se o valor de F significativo para tratamento, procedeu-se à comparação das médias entre cultivares pelo método de análise de agrupamento univariado proposto por Scott-Knott (1974), ao nível de $5 \%$. Esse método apresenta a vantagem de classificar as médias em grupos distintos eliminando qualquer efeito subjetivo no momento da separação dos grupos. Segundo Da Silva (1999), a utilização do teste de Scott-Knott é recomendada, por possuir poder elevado, taxas de erro tipo I quase sempre de acordo com os níveis nominais e por apresentar resultados com ausência de ambigüidade. Esse teste também favorece a diferenciação clara dos melhores tratamentos, por ter eliminado a ambigüidade, a qual se constitui um complicador adicional para a interpretação e para a tomada de decisão (Ferreira, 1999).

\subsection{Parâmetros avaliados}

\subsubsection{Características de produção}

Os critérios adotados na avaliação das características relacionadas à produção foram os seguintes:

a) Produção total de frutos (PT) - representa a produção média de frutos por planta, expressa em gramas por planta, e acumulada nas diferentes etapas de colheita; 
b) Produção de frutos comerciais (PC) - obtido pela soma da pesagem dos frutos classificados dentro dos padrões comerciais nas diferentes datas de colheita por parcela, expressa em gramas por planta;

c) Número total de frutos (NT) - obtido pela soma do número de todos os frutos colhidos nas diferentes datas de colheita por parcela e obtida a média de oito plantas, a fim de estabelecer o número médio de frutos por planta;

d) Número de frutos comerciais (NC) - obtido pela soma do número de frutos classificados dentro dos padrões comerciais nas diferentes datas de colheita e obtida a média de oito plantas, a fim de estabelecer o número médio de frutos comerciais por planta;

e) Peso médio de frutos comerciais (FM) - constitui a relação entre PC e NC nas diferentes datas de colheita por parcela, em termos médios;

g) Número total de frutos por racemo (FR) - determinado com base na relação entre NT e o número médio de racemos por planta.

\subsubsection{Características do fruto}

a) Classificação comercial dos frutos (CC) - a classificação dos frutos se baseou nas Normas de Classificação estabelecidas pelo Centro de Qualidade em Horticultura/Ceagesp, pertencente ao Programa Brasileiro para Modernização da Horticultura (CQH/CEAGESP, 2003). Os frutos colhidos foram classificados individualmente de acordo com o diâmetro equatorial (em mm). Pelas normas adotadas, foram considerados frutos com padrão comercial aqueles que não exibem defeitos e que se enquadram entre as classes 40 e 90. Os frutos de classes 50 e 60 são os de maior aceitação comercial. Os frutos não-comerciais (refugos) são aqueles que se enquadraram nas classes 0 e 100 e que mostraram defeitos;

b) Número de lóculos por fruto (NL) - 10 frutos maduros foram cortados longitudinalmente, contando-se o número de lóculos nas categorias bi, tri, tetra e pluriloculares; 
c) Cicatriz peduncular (CP) - pequena $(P)$, média $(M)$, grande $(G)$ ou extra-grande (XG). Por esse critério, foi considerado pequena uma cicatriz com diâmetro de 3,0 a 4,0 mm, média, entre 4,1 a 5,0 mm, grande, entre 5,1 a 10,0 $\mathrm{mm}$ e extra-grande, entre 10,1 a 14,0 mm. Essa característica foi avaliada com o auxílio de um paquímetro;

d) Firmeza do fruto (FF) - foi avaliada de forma subjetiva, pressionandose manualmente os frutos maduros. O grau de consistência foi avaliado de acordo com uma escala de notas, cujos valores variaram de 1,0 (fruto muito mole) a 5,0 (fruto muito firme). A determinação da firmeza por método subjetivo tem se mostrado altamente correlacionado com a medição feita por métodos não-destrutivos, utilizando instrumentos apropriados para avaliar essa característica (Macnish et al., 1997).

\subsubsection{Avaliação de danos fitossanitários}

A ocorrência de pragas foi avaliada durante a classificação dos frutos, em cada data de colheita. Durante o processo de classificação foram anotados o número de frutos que exibiam danos característicos causados pelas principais pragas: traça-do-tomateiro ( $T$. absoluta)(Anexo J, Fig. 1), broca-pequena-dofruto (Anexo J, Fig. 102), broca-grande-do-fruto e percevejos (Phthia picta)( Anexo J, Fig. 3). O nível de dano em cada um dos cultivares avaliados foi expresso em porcentual. Não foi realizada análise estatística para essa avaliação.

A incidência de nematóides foi avaliada após a última colheita dos dois experimentos conduzidos. Inicialmente, foi feita uma observação geral do sistema radicular das plantas em cada parcela, com o objetivo de verificar se havia homogeneidade de incidência do patógeno dentro das parcelas. Foram, então, retiradas três amostras de cada tratamento, as quais foram avaliadas visualmente utilizando-se escala de notas oscilando de 0 a 100\%, sendo o valor 0 \% para o tratamento cujas raízes não apresentavam nenhuma galha e o valor 
100\% para o que apresentava raízes totalmente infestadas. Esse procedimento de avaliação foi recomendado pelo Prof. Dr. Mario M. Inomoto, do Departamento de Entomologia, Fitopatologia e Zoologia Agrícola, da USP/ESALQ. Amostras de raízes foram também retiradas e enviadas para o laboratório de nematologia da USP/ESALQ, visando identificar a espécie de nematóide predominante nas áreas onde os experimentos foram conduzidos.

Foi feita, ainda, uma observação visual das doenças que incidiram nos dois experimentos. Contudo, não se fez avaliação para quantificar o nível de danos causado por cada uma das doenças identificadas. 


\section{RESULTADOS}

\subsection{Experimento I, Ibiúna, SP}

\subsubsection{Componentes da produção}

\subsubsection{Peso total (PT) e comercial (PC) de frutos}

Nesse experimento foi adotada a poda apical drástica, mantendo-se três inflorescências por planta, sendo explorado, portanto, apenas $1 / 3$ da capacidade produtiva do cultivar, uma vez que, a poda apical convencional é realizada após o oitavo ou nono racemo. Essa prática vem sendo adotada pelo produtor onde o experimento foi conduzido, visando, principalmente, reduzir o período de colheita e, dessa forma, diminuir os efeitos dos ataques de pragas e doenças.

Os resultados para PT apresentados na Tabela 6 mostram que os híbridos Sahel e Colibri superaram todos os demais tratamentos, inclusive diferiram estatisticamente do cultivar-padrão, Saladete DRW 3410. Os cultivares comuns (PL), San Marzano (294,2 g/planta), Raminho Sel. IPA (301,5 g/planta) e HTX - 5415 (702,3 g/planta) mostraram potencial produtivo inferior aos híbridos testados, exceto HTX 8027, que não diferiu estatisticamente da cultivar comum HTX - 5415. 
Tabela 6. Médias de produção total (PT) e comercial (PC) de frutos, e porcentagem da produção de frutos comerciais, experimento I, Ibiúna, SP, 2004

\begin{tabular}{|c|c|c|c|c|c|}
\hline Cultivares & \multicolumn{3}{|c|}{ (g/planta) } & & $\%$ de FC \\
\hline Avalon & $1334,9(36,30)$ & $\mathrm{b}$ & $869,4(28,89)$ & b & 64,6 \\
\hline Colibri & $1870,6(42,96)$ & a & $1309,0(35,71)$ & a & 69,9 \\
\hline HTX - 5415 & $702,3(26,26)$ & c & $452,1(20,74)$ & c & 64,4 \\
\hline HTX - 8027 & $859,9(29,23)$ & c & $592,4(24,30)$ & b & 68,9 \\
\hline Sahel & $2177,7(46,36)$ & a & $1474,0(38,10)$ & a & 67,7 \\
\hline San Marzano & $294,2(17,11)$ & d & $145,2(11,94)$ & d & 49,4 \\
\hline San Vito & $1028,0(31,69)$ & b & $666,8(25,50)$ & b & 64,9 \\
\hline Júpiter & $1366,8(36,86)$ & b & $916,8(30,15)$ & b & 67,0 \\
\hline Raminho & $301,3(16,48)$ & d & $177,4(12,53)$ & d & 58,9 \\
\hline Saladete DRW 3410 & $1421,9(37,61)$ & b & $1103,0(33,04)$ & $\mathrm{a}$ & 77,5 \\
\hline Média & $1136,8(32,09)$ & & $770,6(26,09)$ & & 67,8 \\
\hline Erro Padrão & $44,4(0,63)$ & & $121,2(2,08)$ & & --- \\
\hline C.V. & $(13,9)$ & & $(17,84)$ & & --- \\
\hline
\end{tabular}

Médias seguidas de mesma letra não diferem entre si pelo teste de Scott-Knott $(P>0,05)$. Valores entre parênteses referem-se aos dados transformados em $\sqrt{x}$.

Os resultados praticamente se repetem para o caráter PC. Os híbridos Saladete DRW 3410, Colibri e Sahel obtiveram 77,5 \%, 69,9 \% e 67,7 \% de frutos comercializáveis em relação à produção total de frutos. Os menores percentuais de frutos comercializáveis foram auferidos pelos cultivares comuns San Marzano (49,4 \%) e Raminho Sel. IPA (58,9\%).

Esses resultados concordam com os reportados por Bettiol et al. (2004), onde o híbrido Débora mostrou produtividade significativamente superior à da cv. Santa Clara, em cultivo orgânico. Por isso, para Diver et al. (1999), a escolha de cultivar, é essencial para se obter melhores níveis de rendimento comercial de frutos no cultivo de tomate orgânico. Esses autores enfatizam que, o uso de híbridos com resistência a doenças é fator-chave no manejo integrado de pragas e doenças em sistemas orgânicos.

\subsubsection{Número total (NT) e comercial (NC) de frutos}


Os híbridos Sahel e San Vito, foram, entre todos os cultivares testados, os que apresentaram maiores médias para os parâmetros NT e NC, não diferindo estatisticamente entre si. Os cultivares San Marzano e Raminho Sel. IPA obtiveram os piores resultados para esses parâmetros (Tabela 7).

Tabela 7. Médias do número total (NT) e comercial (NC) de frutos e porcentagem do número de frutos comerciais, experimento I, Ibiúna, $\mathrm{SP}, 2004$

\begin{tabular}{|c|c|c|c|c|}
\hline Cultivares & NT & (n $/$ planta) & NC & $\%$ de NC \\
\hline Avalon & 115,6 & $\mathrm{~b}$ & 70,8 & 61,2 \\
\hline Colibri & 135,6 & b & 86,6 & 63,8 \\
\hline HTX - 5415 & 87,4 & c & 50,8 & 58,1 \\
\hline HTX - 8027 & 114,2 & b & 73,2 & 64,1 \\
\hline Sahel & 157,0 & $\mathrm{a}$ & 103,6 & 65,9 \\
\hline San Marzano & 53,4 & d & 23,2 & 43,4 \\
\hline San Vito & 166,8 & a & 113,6 & 68,1 \\
\hline Júpiter & 126,6 & $b$ & 74,0 & 58,4 \\
\hline Raminho & 38,8 & $\mathrm{~d}$ & 19,0 & 48,9 \\
\hline Saladete DRW 3410 & 119,4 & $b$ & 86,6 & 72,5 \\
\hline Média & 111,4 & & 70,1 & 62,9 \\
\hline Erro Padrão & 3,6 & & 2,9 & --- \\
\hline C.V. & 22,7 & & 29,7 & --- \\
\hline
\end{tabular}

\subsubsection{Peso médio de frutos comerciais (FM) e número médio de frutos por racemo (FR)}

Os híbridos Sahel (113,8 g), Colibri (119,1 g), Saladete DRW 3410 (104,3 g) e Júpiter $(101,7 \mathrm{~g})$ foram os que apresentaram frutos comerciais com pesos médios maiores, não diferindo estatisticamente entre si. HTX - 5415, HTX 8027 e Raminho Sel. IPA apresentaram resultados intermediários, e não diferiram estatisticamente entre si. Os piores resultados foram observados nos cultivares San Marzano e San Vito, que obtiveram peso médio de fruto inferior a $50 \mathrm{~g}$ (Tabela 8). 
Tabela 8. Médias de peso de frutos comerciais (FM) e do número de frutos por racemo (FR), experimento I, Ibiúna, SP, 2004

\begin{tabular}{|c|c|c|c|c|}
\hline Cultivar & \multicolumn{2}{|c|}{ FM (q) } & \multicolumn{2}{|c|}{ FR $\left(n^{\circ}\right)$} \\
\hline Avalon & 102,6 & $a$ & 4,5 & $\mathrm{~b}$ \\
\hline Colibri & 119,1 & a & 5,6 & b \\
\hline HTX - 5415 & 71,2 & $b$ & 3,6 & C \\
\hline HTX - 8027 & 64,3 & $b$ & 4,7 & $b$ \\
\hline Sahel & 113,8 & a & 6,5 & a \\
\hline San Marzano & 49,8 & c & 2,4 & $d$ \\
\hline San Vito & 48,5 & c & 6,9 & a \\
\hline Júpiter & 101,7 & a & 5,6 & b \\
\hline Raminho & 70,6 & $b$ & 1,9 & $d$ \\
\hline Saladete DRW 3410 & 104,3 & a & 5,0 & $b$ \\
\hline Média & 84,9 & & 4,7 & \\
\hline Erro Padrão & 2,4 & & 0,14 & \\
\hline C.V. & 20 & & 21,1 & \\
\hline
\end{tabular}

Médias seguidas de mesma letra não diferem entre si pelo teste de Scott-Knott $(P>0,05)$.

Ficou evidente, mais uma vez, o fraco desempenho dos cultivares comuns Raminho Sel. IPA e San Marzano, que produziram, em média, dois frutos por racemo. Os melhores resultados foram obtidos pelos híbridos Sahel $(6,5)$ e San Vito $(6,9)$ que não diferiram entre si, estatisticamente. Os híbridos Avalon, Colibri, Júpiter, HTX - 8027 e Saladete DRW 3410 produziram, em média, cinco frutos por racemo, configurando um número ideal de frutos para esse tipo de tomate.

Atualmente, é comum entre os produtores de híbridos de tomate dos tipos Santa Cruz e Italiano, tanto em sistema convencional como no orgânico, a poda de frutos, conhecida como "despenca", deixando 5-6 frutos/racemo. O objetivo dessa prática cultural é a obtenção de maior uniformidade de frutificação e incremento do porcentual de frutos com calibre de melhor cotação comercial (Alvarenga, 2004).

\subsubsection{Características do fruto}

\subsubsection{Classificação comercial dos frutos (CC)}


Pelas normas oficiais de classificação, adotadas nesse trabalho, são considerados de padrão comercial os frutos isentos de defeitos e que se enquadram entre as classes 40 e $90 \mathrm{~mm}$. Os frutos das classes 50 e $60 \mathrm{~mm}$ são de maior aceitação no mercado.

Os resultados apresentados na Tabela 9 mostram que, em média, 69,3 $\%$ dos frutos produzidos alcançaram padrão de qualidade para comercialização e que $40,6 \%$ deles foram incluídos nas classes 50 e 60 de melhor aceitação comercial. As maiores porcentagens de frutos com calibre abaixo de $40 \mathrm{~mm}$ e, portanto, refugados pelas normas, foram apresentados pelos cultivares San Marzano (68,0 \%), San Vito (59 \%), Raminho Sel. IPA (55 \%), Júpiter (30 \%) e HTX - 5415 (29\%). Entre os híbridos, destacaram-se pela baixa porcentagem de frutos refugados, Avalon (7\%) e Sahel ( $9 \%)$, diferindo ambos, da cultivarpadrão Saladete DRW 3410 (17 \%).

De outro lado, se sobressaíram os híbridos Avalon (72\%), Sahel (66 \%), Colibri (59 \%) e Saladete DRW 3410 (57 \%) pela alta porcentagem de frutos de melhor cotação comercial (classes de 50 e $60 \mathrm{~mm}$ ).

Os resultados chamam a atenção para o fato de que nenhum dos cultivares produziu frutos de classes superiores a $60 \mathrm{~mm}$. Isso já era esperado por que as cultivares testadas pertencem aos tipos Santa Cruz e Italiano, cujo peso médio de fruto, raramente, é maior do que $140 \mathrm{~g}$, mesmo em sistema de cultivo convencional, com adoção da despenca.

Merece ser destacado, ainda, que os híbridos, em geral, superaram as variedades comuns apresentando menores porcentuais de frutos refugados e maior porcentagem de frutos classificados como de maior aceitação comercial. 
Tabela 9. Porcentagem de frutos dentro das oito classes de diâmetro equatorial (em mm), experimento I, Ibiúna, SP, 2004

\begin{tabular}{lcccccccc}
\hline \multicolumn{1}{c}{ Tratamento } & $\mathbf{0}$ & $\mathbf{4 0}$ & $\mathbf{5 0}$ & $\mathbf{6 0}$ & $\mathbf{7 0}$ & $\mathbf{8 0}$ & $\mathbf{9 0}$ & $\mathbf{1 0 0}$ \\
\hline Avalon & 7 & 18 & 43 & 29 & 3 & 0 & 0 & 0 \\
Colibri F1 & 15 & 25 & 38 & 21 & 1 & 0 & 0 & 0 \\
HTX - 5415 & 29 & 38 & 28 & 5 & 0 & 0 & 0 & 0 \\
HTX - 8027 & 18 & 37 & 35 & 10 & 0 & 0 & 0 & 0 \\
Sahel & 9 & 21 & 37 & 29 & 4 & 0 & 0 & 0 \\
San Marzano & 68 & 22 & 10 & 0 & 0 & 0 & 0 & 0 \\
San Vito & 59 & 28 & 13 & 0 & 0 & 0 & 0 & 0 \\
Júpiter & 30 & 38 & 27 & 5 & 0 & 0 & 0 & 0 \\
Raminho & 55 & 22 & 9 & 10 & 4 & 0 & 0 & 0 \\
Saladete DRW 3410 & 17 & 26 & 45 & 12 & 0 & 0 & 0 & 0 \\
Média & 30,7 & 27,5 & 28,5 & 12,1 & 1,2 & 0,0 & 0,0 & 0,0 \\
\hline
\end{tabular}

\subsubsection{Número de lóculos, cicatriz peduncular e firmeza de frutos}

Os cultivares testados apresentaram número de lóculos que variou de dois, para San Marzano, San Vito, Júpiter, e HTX - 8027, a até quatro lóculos no Sahel.(Tabela 10).

Tabela 10. Número de lóculos (NL), tamanho da cicatriz peduncular (CP) e firmeza do fruto (FF), experimento I, Ibiúna, SP

\begin{tabular}{lccc}
\hline \multicolumn{1}{c}{ Cultivares } & NL & CP & FF \\
\hline Avalon & 3 & G & 3,0 \\
Colibri & 3 & G & 4,5 \\
HTX -5415 & 3 & G & 5,0 \\
HTX -8027 & 2 & G & 5,0 \\
Sahel & 4 & G & 3,0 \\
San Marzano & 2 & P & 1,0 \\
San Vito & 2 & G & 4,5 \\
Júpiter & 2 & G & 2,5 \\
Raminho & 3 & XG & 2,0 \\
Saladete DRW 3410 & 3 & M & 4,5 \\
\hline
\end{tabular}

A firmeza do fruto, aferida manualmente, define um importante fator para a durabilidade pós-colheita. A cultivar que apresentou o fruto mais mole foi a San Marzano, com nota 1,0, enquanto os cultivares HTX - 5415, HTX - 8027, 
Colibri, Saladete DRW 3410 e San Vito foram avaliados como de alta firmeza. $(\geq 4,5)$. O resultado para os outros cultivares pode ser observado na Tabela 9.

O cultivar Raminho foi o que exibiu maior tamanho de cicatriz peduncular (XG), enquanto a cultivar San Marzano foi a que apresentou o menor tamanho. Os resultados estão apresentados na Tabela 9.

\subsubsection{Danos fitossanitários}

\subsection{Pragas}

A principal praga que ocorreu foi à traça-do-tomateiro. As porcentagens de danos causados por essa praga são apresentadas na Tabela 11.

Tabela 11. Número e porcentagem de frutos danificados pela traça-do-tomateiro nos cultivares avaliados no experimento I, Ibiúna, SP, 2004

\begin{tabular}{lccc}
\hline \multicolumn{1}{c}{ Tratamento } & $\begin{array}{c}\mathbf{N}^{\mathbf{0}} \text { frutos com } \\
\text { traça }\end{array}$ & $\begin{array}{c}\mathbf{N}^{\circ} \text { total de } \\
\text { frutos }\end{array}$ & $\begin{array}{c}\text { \% frutos } \\
\text { danificados }\end{array}$ \\
\hline Avalon & 194 & 578 & 33,56 \\
Colibri F1 & 135 & 678 & 19,91 \\
HTX - 5415 & 137 & 437 & 31,35 \\
HTX - 8027 & 101 & 571 & 17,69 \\
Sahel & 168 & 785 & 21,40 \\
San Marzano & 119 & 267 & 44,57 \\
San Vito & 110 & 834 & 13,19 \\
Júpiter & 158 & 633 & 24,96 \\
Raminho & 39 & 163 & 23,93 \\
Saladete DRW 3410 & 82 & 628 & 13,06 \\
Média & 124,3 & 557,4 & 22,3 \\
\hline
\end{tabular}

Os cultivares menos atacados pela traça-do-tomateiro foram o San Vito e Saladete DRW 3410, ambos com porcentagens de danos em torno de $13 \%$. San Marzano foi a mais atacada pela traça com aproximadamente $45 \%$ dos frutos apresentando algum tipo de dano. Isso, possivelmente, denota o envolvimento de algum mecanismo de preferência do inseto por essa cultivar. Trata-se apenas de uma especulação, mas que poderia ser tema de estudos 
mais aprofundados e que, certamente, ajudariam na recomendação de cultivares mais adequados para sistemas orgânicos.

A porcentagem média de danos causados pela traça-do-tomateiro nos frutos de todos os tratamentos foi de 22,3\%, demonstrando a relevância desta praga para a cultura do tomate em sistema orgânico. A busca por métodos alternativos mais eficazes para o manejo desta praga torna-se um grande desafio para a produção do tomate, principalmente em sistema orgânico de produção, cujo princípio básico é a não utilização de defensivos químicos sintéticos.

\subsection{Doenças}

A avaliação do nível de infestação de nematóide foi realizada visualmente através de uma escala de notas de 0 a 100\% (Anexo $\mathrm{H}$ ). $\mathrm{O}$ resultado da análise pode ser observado na Tabela 12.

Tabela 12: Nível de infestação e espécies de nematóides identificados nos cultivares avaliados no experimento I, Ibiúna, SP, 2004

\begin{tabular}{lcc}
\hline \multicolumn{1}{c}{ Cultivar } & Nível de infestação (\%) & Espécie do nematóide \\
\hline Avalon & $60-80 \%$ & Meloidogyne javanica \\
Colibri F1 & 0 & --- \\
HTX - 5415 & $60-80 \%$ & Meloidogyne javanica \\
HTX - 8027 & 0 & -- \\
Sahel & 0 & --- \\
San Marzano & $80-100 \%$ & Meloidogyne javanica \\
San Vito & 0 & --- \\
Júpiter & 0 & --- \\
Raminho & $80-100 \%$ & Meloidogyne javanica \\
Saladete DRW 3410 & 0 & --- \\
\hline
\end{tabular}

Os híbrido Colibri, Saladete DRW 3410, San Vito, HTX - 8027 e Sahel são por sua descrição varietal portadores do gene Mi, que confere resistência a todas as espécies de Meloidogyne spp., execeto M. hapla (Laterrot, 1973). Os 
resultados obtidos na avaliação procedida comprovam a resistência à espécie M. javanica identificada na área onde o experimento I foi conduzido.

Os cultivares Avalon, Raminho, HTX - 5415 e San Marzano apresentaram sintomas típicos de meloidoginose, exibindo infestação de galhas nas raízes. O nível de infestação variou entre 60 a 100\%.

As doenças observadas e avaliadas visualmente pelo nível de incidência, encontram-se na tabela 13.

Tabela 13. Nível de incidência de Requeima (PI) e de Mancha-de-cladospório (FF), experimento I, Ibiúna, SP, 2004

\begin{tabular}{lcc}
\hline \multicolumn{1}{c}{ Cultivar } & FF & PI \\
\hline Avalon & A & M \\
Colibri & M & A \\
HTX -5415 & $\mathrm{M}$ & NO \\
HTX -8027 & $\mathrm{~A}$ & $\mathrm{NO}$ \\
Sahel & $\mathrm{A}$ & $\mathrm{B}$ \\
San Marzano & $\mathrm{A}$ & $\mathrm{A}$ \\
San Vito & $\mathrm{A}$ & $\mathrm{A}$ \\
Júpiter & $\mathrm{A}$ & $\mathrm{A}$ \\
Raminho & $\mathrm{B}$ & $\mathrm{M}$ \\
Saladete DRW 3410 & $\mathrm{B}$ &
\end{tabular}

Os cultivares, em geral, exibiram alta sensibilidade à mancha-de cladospório, doença reconhecidamente problemática em cultivo protegido (Lopes \& Santos, 1994). Portanto, torna-se imprescindível a identificação de cultivares resistentes a essa doença para o cultivo orgânico.

Com relação à requeima, a maioria dos cultivares testados mostrou-se susceptíveis em grau mediano e alto. Essa doença constitui um dos gargalos da produção orgânica de tomate, especialmente, em regiões sujeitas a baixas temperaturas e umidade relativa. (Diver et al., 1999 e Lopes \& Santos, 1994). Além disso, não existem no mercado cultivares geneticamente resistentes. 
Os resultados mostram, com bastante clareza, a relevância da resistência genética incorporada nos híbridos testados, que exibiram melhor desempenho em termos de rendimento comercial (Sahel, Saladete DRW 3410 e Colibri). De novo, fica evidente, a vantagem de híbridos com resistência a nematóides e outras doenças, em relação às variedades comuns.

\subsection{Experimento II, Araraquara, SP}

\subsubsection{Componentes da produção}

\subsubsection{Peso total (PT) e comercial (PC) de frutos}

Além do período de realização do experimento ter coincidido com a época mais favorável para o cultivo de tomate na região, nesse experimento, às plantas foram conduzidas com duas hastes por planta, sem poda apical, propiciando a exploração de toda a capacidade produtiva dos cultivares avaliados.

O híbrido Sahel alcançou os melhores resultados de PT e PC, superando estatisticamente os demais tratamentos. Em seguida, encontra-se o híbrido San Vito, com valores de PT e PC de 4,60 e 2,63 kg/planta, respectivamente.

Colibri apresentou o menor potencial produtivo, tanto para PT como para PC. Porém, em relação a PC não diferiu estatisticamente do híbrido HTX 8027. Avalon, HTX - 5415, San Marzano e Jane obtiveram resultados intermediários para os dois parâmetros estudados. O híbrido Sahel também apresentou a maior porcentagem de frutos comerciais $(66,9 \%)$, pouco acima do híbrido Jane (66,2\%).

No sistema de condução adotada e nas condições experimentais, os cultivares comuns (PL) apresentaram resultados satisfatórios, sendo superados pelos híbridos Sahel e San Vito, mas apresentaram resultados superiores aos híbridos Colibri e HTX - 8027. 
De acordo com o espaçamento adotado (0,80 m entre linhas e 0,60 m entre plantas), obtém-se uma densidade de 20.000 plantas por hectare, proporcionando, nos melhores cultivares avaliados, produtividades comerciais de aproximadamente $77 \mathrm{t} / \mathrm{ha}$.

Tabela 14. Médias de produção total (PT) e comercial (PC) de frutos, e porcentagem da produção de frutos comerciais, experimento II, Araraquara, SP, 2004

\begin{tabular}{lrrrrr}
\hline \multicolumn{1}{c}{ Cultivares } & PT & PC & \% de FC \\
\hline Avalon & 3122,6 & $\mathrm{C}$ & $1790,9(3,25)$ & $\mathrm{C}$ & 56,3 \\
Colibri F1 & 2183,5 & $\mathrm{~d}$ & $1154,3(3,04)$ & $\mathrm{d}$ & 52,8 \\
HTX - 5415 & 3457,2 & $\mathrm{C}$ & $2032,5(3,30)$ & $\mathrm{C}$ & 58,8 \\
HTX - 8027 & 3306,9 & $\mathrm{C}$ & $1492,8(3,15)$ & $\mathrm{d}$ & 45,1 \\
Sahel & 5763,7 & $\mathrm{a}$ & $3856,4(3,58)$ & $\mathrm{a}$ & 66,9 \\
San Marzano & 3086,2 & $\mathrm{C}$ & $1771,2(3,24)$ & $\mathrm{C}$ & 57,4 \\
San Vito & 4606,3 & $\mathrm{~b}$ & $2635,4(3,40)$ & $\mathrm{b}$ & 57,2 \\
Jane & 3295,5 & $\mathrm{C}$ & $2180,7(3,32)$ & $\mathrm{C}$ & 66,2 \\
Média & 3602,8 & & $2111,4(3,28)$ & 58,5 \\
Erro Padrão & 66,6 & $212,7(0,04)$ & --- \\
Coeficiente de variação & 13,1 & $(2,56)$ & --- \\
\hline Médias seguidas de mesma letra não diferem entre si pelo Teste de Scott-Knott (P>0,05). * \\
valores entre parênteses referem-se a dados transformados em log(x).
\end{tabular}

\subsubsection{Número total (NT) e comercial (NC) de frutos}

Os híbridos Sahel e San Vito apresentaram maiores médias para NT, não diferindo estatisticamente entre si. Porém para NC o híbrido Sahel, por apresentar maior porcentagem de frutos comerciais $(53,2 \%)$ diferiu do San Vito.

Para NT as piores médias foram observadas nos cultivares Colibri e Jane. Para a produção de frutos comerciais, o híbrido HTX - 8027 e novamente Colibri, obtiveram as menores médias, não diferindo estatisticamente entre si.

Como observado para PT e PC, os cultivares comuns, também apresentaram para NT e NC, médias superiores aos híbridos HTX - 8027 e 
Colibri, demonstrando uma melhor adaptação desses cultivares ao sistema de cultivo adotado.

Tabela 15. Médias do número total (NT) e comercial (NC) de frutos e porcentagem do número de frutos comerciais, experimento II, Araraquara, SP, 2004

\begin{tabular}{lccccc}
\hline \multicolumn{1}{c}{ Cultivares } & NT & NC & & \% de NC \\
& \multicolumn{3}{c}{ (em gramas) } \\
\hline Avalon & 44,6 & $\mathrm{c}$ & 17,2 & $\mathrm{C}$ & 38,6 \\
Colibri & 32,2 & $\mathrm{~d}$ & 13,0 & $\mathrm{~d}$ & 40,3 \\
HTX - 5415 & 49,3 & $\mathrm{C}$ & 21,4 & $\mathrm{C}$ & 43,3 \\
HTX - 8027 & 55,4 & $\mathrm{~b}$ & 17,5 & $\mathrm{C}$ & 31,5 \\
Sahel & 68,9 & $\mathrm{a}$ & 40,3 & $\mathrm{a}$ & 53,2 \\
San Marzano & 59,2 & $\mathrm{~b}$ & 28,7 & $\mathrm{C}$ & 48,4 \\
San Vito & 68,2 & $\mathrm{a}$ & 30,7 & $\mathrm{~b}$ & 45,0 \\
Jane & 34,8 & $\mathrm{~d}$ & 17,8 & $\mathrm{C}$ & 51,2 \\
Média & 51,6 & & 23,3 & & 44,4 \\
Erro Padrão & 0,80 & & & --- \\
Coeficiente de variação & 10,9 & & & --- \\
\hline Médias seguidas de mesma letra não diferem entre si pelo Teste de Scott-Knott (P>0,05).
\end{tabular}

\subsubsection{Peso médio de frutos comerciais (FM) e número médio de frutos por racemo (FR)}

O cultivar-padrão Jane apresentou o maior FM, fato justificável por ser o único cultivar entre os testados pertencente ao grupo caqui, que normalmente produz frutos maiores. Entre os demais cultivares testados, o híbrido Sahel se destacou positivamente mais uma vez, obtendo peso médio de frutos estatisticamente superior aos demais cultivares testados. HTX - 8027 e San Marzano demonstraram os piores resultados.

Para FR, os cultivares HTX - 8027, Sahel, San Marzano e San Vito apresentaram as maiores médias com, em média, 5,5 frutos por racemo, considerado um número ideal de frutos por racemo para esse segmento de tomate. A média mais baixa para FR foi obtida pelo híbrido Jane. Menor número 
de frutos por cacho nesse segmento de tomate, em geral, favorece a um maior peso médio de frutos, de melhor aceitação comercial.

Tabela 16. Médias de peso de frutos comerciais (FM) e do número de frutos por racemo (FR), experimento II, Araraquara, SP, 2004

\begin{tabular}{|c|c|c|c|c|}
\hline Cultivares & FM (g) & & FR $\left(n^{0}\right)$ & \\
\hline Avalon & 70,0 & c & 4,5 & $\mathrm{~b}$ \\
\hline Colibri F1 & 67,7 & c & 4,0 & $\mathrm{~b}$ \\
\hline HTX - 5415 & 70,2 & c & 4,9 & $\mathrm{~b}$ \\
\hline HTX - 8027 & 59,6 & $d$ & 5,6 & $\mathrm{a}$ \\
\hline Sahel & 84,2 & $\mathrm{~b}$ & 6,4 & $\mathrm{a}$ \\
\hline San Marzano & 51,9 & d & 5,9 & $\mathrm{a}$ \\
\hline San Vito & 67,5 & c & 5,6 & a \\
\hline Jane & 94,4 & a & 3,7 & $\mathrm{c}$ \\
\hline Média & 70,7 & & 5,1 & \\
\hline Erro Padrão & 0,74 & & 0,081 & \\
\hline Coeficiente de variação & 7,4 & & 11,2 & \\
\hline
\end{tabular}

\subsubsection{Características do fruto}

\subsubsection{Classificação comercial dos frutos (CC)}

Em média, 69,3\% dos frutos foram classificados dentro dos padrões de qualidade para comercialização, sendo $31,8 \%$ nas classes 50 e 60 , de maior aceitação comercial. Os híbridos Sahel e Jane apresentaram a maior porcentagem de frutos comerciais (82 \%). Por outro lado, a variedade San Marzano obteve a maior porcentagem de frutos refugados (54\%), obtendo, portanto, apenas $46 \%$ dos frutos dentro dos padões de qualidade para comercialização.

Valores significativos de refugos, também foram observados nos cultivares HTX - 5415, HTX - 8027 e San Vito, com mais de $30 \%$ de frutos não alcançando padrão de comercialização.

Os cultivares comuns, em geral, apresentaram maior porcentagem de frutos refugados (43,5\%) quando comparados aos híbridos (26,5\%). 
Tabela 17: Porcentagem de frutos dentro das oito classes de diâmetro equatorial (em mm), experimento II, Araraquara, SP, 2004

Porcentagem de frutos

\begin{tabular}{lcccccccc}
\multicolumn{1}{c}{ Tratamento } & $\mathbf{0}$ & $\mathbf{4 0}$ & $\mathbf{5 0}$ & $\mathbf{6 0}$ & $\mathbf{7 0}$ & $\mathbf{8 0}$ & $\mathbf{9 0}$ & $\mathbf{1 0 0}$ \\
\hline Avalon & 26 & 31 & 30 & 13 & 0 & 0 & 0 & 0 \\
Colibri F1 & 26 & 44 & 29 & 1 & 0 & 0 & 0 & 0 \\
HTX - 5415 & 33 & 39 & 25 & 3 & 0 & 0 & 0 & 0 \\
HTX - 8027 & 32 & 37 & 28 & 3 & 0 & 0 & 0 & 0 \\
Sahel & 18 & 35 & 38 & 9 & 0 & 0 & 0 & 0 \\
San Marzano & 54 & 31 & 15 & 0 & 0 & 0 & 0 & 0 \\
San Vito & 39 & 53 & 6 & 1 & 1 & 0 & 0 & 0 \\
Jane & 18 & 14 & 27 & 26 & 13 & 2 & 0 & 0 \\
Média & 30,7 & 35,5 & 24,8 & 7,0 & 1,75 & 0,25 & 0,0 & 0,0 \\
\hline
\end{tabular}

\subsubsection{Número de lóculos, cicatriz peduncular e firmeza de frutos}

Os parâmetros avaliados (NL, CP e FF) são características que não se alteram com o sistema de condução adotado, pois são intrínsecas a cada cultivar. Com exceção do híbrido Jane, os demais cultivares também foram testados no experimento I, sendo os dados apresentados na Tabela 18, idênticos aos do experimento realizado em Ibiúna.

Tabela 18. Número de lóculos (NL), tamanho da cicatriz peduncular (CP) e firmeza do fruto (FF), experimento II, Araraquara, SP, 2004

\begin{tabular}{lccc}
\hline \multicolumn{1}{c}{ Cultivares } & NL & CP & FF \\
\hline Avalon & 3 & G & 3,0 \\
Colibri & 3 & G & 4,5 \\
HTX -5415 & 3 & G & 5,0 \\
HTX -8027 & 2 & G & 5,0 \\
Sahel & 4 & G & 3,0 \\
San Marzano & 2 & P & 1,0 \\
San Vito & 2 & G & 4,5
\end{tabular}


Tabela 18. Número de lóculos (NL), tamanho da cicatriz peduncular (CP) e firmeza do fruto (FF), experimento II, Araraquara, SP, 2004

\begin{tabular}{lccc}
\hline \multicolumn{1}{c}{ Cultivares } & NL & CP & FF \\
\hline Júpiter & 2 & G & 2,5 \\
Raminho & 3 & XG & 2,0 \\
Jane & $>4$ & XG & 2,5 \\
\hline
\end{tabular}

A cicatriz peduncular (CP) é uma característica muito importante na definição do padrão de qualidade visual do fruto. Em geral, os frutos do tipo caqui, como é o caso do híbrido Jane, têm cicatriz peduncular maior do que a dos cultivares do tipo Santa Cruz e Italiano, que apresentam, também, um menor número de lóculos e frutos de menor tamanho.

\subsubsection{Danos fitossanitários}

\subsection{Pragas}

As principais pragas que ocorreram foram a traça-do-tomateiro ( $T$. absoluta), broca-pequena-do-fruto ( $N$. elegantis), broca-grande-do-fruto (Helicoverpa zeae), percevejo (P. picta) e o ácaro-do-bronzeamento (Aculops lycopersici).

Não foi realizado o levantamento do nível populacional de cada uma das pragas. Entretanto, durante a etapa de classificação dos tomates colhidos, foi identificado o nível de dano causado por cada uma delas (Tabela 19).

Tabela 19. Porcentagem de danos causados nos frutos pelas pragas que ocorreram no experimento II, Araraquara, SP, 2004

\begin{tabular}{lccccc}
\hline & \multicolumn{5}{c}{ Danos nos frutos (\%)* } \\
\multicolumn{1}{c}{ Tratamento } & BGF & BPF & TRA & PER & Total \\
\hline Avalon & 0,6 & 2,8 & 15,9 & 2,0 & 21,4 \\
Colibri F1 & 1,0 & 2,8 & 20,0 & 1,9 & 25,7 \\
HTX - 5415 & 1,0 & 4,2 & 21,1 & 0,8 & 27,0 \\
HTX - 8027 & 0,8 & 1,8 & 14,7 & 1,0 & 18,3 \\
Sahel & 0,8 & 2,5 & 16,6 & 0,2 & 20,1 \\
San Marzano & 1,6 & 3,4 & 16,5 & 0,8 & 22,4
\end{tabular}


Tabela 19. Porcentagens de danos causados nos frutos pelas pragas que ocorreram no experimento II, Araraquara-SP, 2004

\begin{tabular}{lcccccc}
\hline & & \multicolumn{5}{c}{ Danos nos frutos (\%)* } \\
& Tratamento & BGF & BPF & TRA & PER & Total \\
\hline San Vito & 0,8 & 3,9 & 18,9 & 1,0 & 24,6 \\
Jane & 0,4 & 3,7 & 13,0 & 2,0 & 19,0 \\
Média & 0,09 & 3,14 & 17,09 & 1,21 & 22,30 \\
\hline
\end{tabular}

* Legenda: BGF= broca-grande-do-fruto; BPF= broca-pequena-do-fruto; TRA= traça-dotomateiro e $\mathrm{PER}=$ percevejo.

A porcentagem total de ataque de pragas nos oito tratamentos variou de 18,3\%, no híbrido HTX - 8027 , a $27 \%$ no cultivar HTX - 5415, sendo a média de $22,3 \%$. Ou seja, isoladamente, foram responsáveis por quase um quarto das perdas registradas nos frutos. As pragas, desse modo, ainda são uma grande dificuldade encontrada no sistema orgânico de produção, apesar de existirem no mercado produtos destinados ao seu controle e que foram utilizados na propriedade, onde o experimento foi conduzido.

A traça-do-tomateiro, como no experimento I, foi a principal praga, com um nível médio de infestação de 17 \%. O cultivar HTX - 5415 apresentou a maior porcentagem de frutos atacados pela traça, enquanto, os híbridos HTX 8027 e Jane as menores porcentagens de frutos atacados, exibindo menos de $15 \%$ de dano.

\subsection{Doenças}

A avaliação do nível de infestação de nematóide foi realizada visualmente através de uma escala de notas de 0 a 100\% (Anexo $\mathrm{H}$ ). O resultado da análise pode ser observado na Tabela 20.

Tabela 20. Nível de infestação e espécies de nematóide presente nos cultivares avaliados, experimento II, Araraquara, SP, 2004

\begin{tabular}{lcc}
\hline \multicolumn{1}{c}{ Cultivar } & Nível de infestação (\%) & Espécie do nematóide \\
\hline Avalon & $20-40 \%$ & $\mathrm{Mi}, \mathrm{Mj}, \mathrm{Ma}$ \\
Colibri F1 & $20-40 \%$ & $\mathrm{Mi}$ \\
\hline
\end{tabular}


Tabela 20. Nível de infestação e espécies de nematóide presente nos cultivares avaliados no experimento II, Araraquara-SP, 2004

\begin{tabular}{lcc}
\hline \multicolumn{1}{c}{ Cultivar } & Nível de infestação (\%) & Espécie do nematóide \\
\hline HTX - 5415 & 0 & \\
HTX - 8027 & $20-40 \%$ & $\mathrm{Mi}, \mathrm{Ma}$ \\
Sahel & $0-10 \%$ & $\mathrm{Mi}$ \\
San Marzano & $60-80 \%$ & $\mathrm{Mi}, \mathrm{Mj}, \mathrm{Ma}$ \\
San Vito & $0-5 \%$ & $\mathrm{Mi}$ \\
Jane & $80-100 \%$ & $\mathrm{Mi}, \mathrm{Mj}$ \\
Legenda: Mi= Meloidogyne incógnita; Mj= Meloidogyne javanica e Ma= Meloidogyne \\
arenaria.
\end{tabular}

A análise das amostras coletadas, na área onde o experimento II foi conduzido, detectou a presença de $M$. javanica, $M$. incógnita e $M$. arenaria, enquanto que no experimento I ocorreu apenas $M$. javanica.

Os cultivares San Marzano (60 a 80 \%) e Jane (80 a 100 \%), destacaram-se pela mais alta infestação por diferentes espécies de Meloidogyne. Entre os demais cultivares avaliados, Avalon, Colibri e HTX 8027 apresentaram de 20 a 40 \% de infestação, e HTX - 5415 e San Vito comportaram-se como resistentes.

Chama a atenção o fato de que cultivares resistentes a nematóide, como Colibri (20 a 40 \%), HTX - 8027 (20 a 40 \%), Sahel (0 a $10 \%$ ), e San Vito (0 a $5 \%$ ), mostraram níveis variáveis de galhas em suas raízes. O gene Mi, incorporado nesses cultivares, confere resistência incompleta a nematóides causadores de galhas, Meloidogyne spp., exceto M. hapla. Além disso, é um exemplo típico de resistência condicional, ou seja, sob condições de temperaturas acima de $28{ }^{\circ} \mathrm{C}$, a resistência é reduzida (Laterrot, 1973; Clergeau et al., 1979 e Melo, 1984).

Dessa forma, a diferença de comportamento dos cultivares resistentes deve estar relacionada às temperaturas mais elevadas que são registradas em Araraquara, onde o experimento II foi conduzido.

As doenças que incidiram na área foram a requeima, a mancha-deseptoria, a murcha-de-verticílio e o tospovírus (vira-cabeça do tomateiro) 
(Anexo J, Fig. 4). Vale registrar que, essas doenças não causaram danos econômicos. Na avaliação do produtor, só se justificou a adoção de medidas de controle para a requeima, feita com pulverizações de calda bordalesa.

\subsection{Comparações entre os experimentos}

Os experimentos foram conduzidos em áreas pertencentes a produtores que exploram comercialmente a produção de tomate em sistema orgânico. Embora ambas sejam certificadas pelo IBD, as práticas culturais não são as mesmas. As principais diferenças referem-se ao sistema de condução das plantas, ao tipo de estufa, à adubação, ao manejo de plantas invasoras e de pragas e doenças. Além disso, estão localizados em regiões geográficas do estado de São Paulo, que apresentam condições climáticas totalmente distintas. Deve ser ressaltado, ainda, que o experimento I foi transplantado em maio, e todo o período de florescimento e pegamento de fruto ocorreu sob temperaturas adversas. Em Ibiúna, a implantação dos cultivos orgânicos de tomate, concentra-se nos meses de outubro a fevereiro. Já em Araraquara, a época mais favorável ocorre durante o inverno.

No experimento I, a produção é feita em estufas conjugadas e fechada lateralmente com telas anti-afídeos e cobertas com plástico de luz difusa. A planta é conduzida em linha simples, com uma haste por planta, e com poda apical drástica, acima do terceiro racemo. No solo foi incorporada aveia preta, e posteriormente, coberto com mulching plástico, a irrigação feita por gotejo, utilizado também na realização de fertirrigação com biofertilizantes.

No experimento 2, as estufas não são conjugadas e são abertas lateralmente. O canteiro é coberto com mulching vegetal (cobertura morta), e o plantio é feito em linhas duplas deixando-se duas hastes por planta, sem poda apical. A adubação é praticamente toda realizada no plantio, sendo a irrigação feita por gotejo. 
Portanto fica, evidente que o sistema de cultivo adotado pelo produtor de Ibiúna é mais sofisticado do que o empregado pelo produtor de Araraquara. Esse produtor adota manejo mais simples, menos intensivo, e com menor utilização de insumos e mão-de-obra.

Fica claro que, na agricultura orgânica, cada produtor, adapta seu sistema produtivo às necessidades da região e da propriedade, sendo que não podemos afirmar que um sistema é melhor que outro. Certamente, o sistema adotado em Ibiúna não iria produzir os mesmos resultados em Araraquara, e vice-versa. O que será tratado, a partir de agora, são as diferenças existentes entre os dois sistemas e os reflexos causados nos parâmetros avaliados.

\subsubsection{Componentes da produção}

O experimento II apresentou maior produção total (PT) e comercial (PC), maior número total (NT) e comercial (NC) de frutos por planta, devido ao sistema de condução adotado, de duas hastes por planta sem poda apical (Tabelas 21 e 22). Esse sistema de condução, quando comparado à poda drástica empregada no experimento II, propicia maiores valores de produção por planta. Uma das vantagens da realização da poda drástica parece estar associada ao incremento do tamanho do fruto, o que foi comprovado pelas maiores médias de FM obtidas no experimento I (Tabela 23). Os dois experimentos apresentaram valores médios de frutos por racemo (FR) próximos, porém o Experimento II, na média, obteve valores maiores (Tabela 23).

Tabela 21. Médias de produção total (PT) e comercial (PC) de frutos, e porcentagem da produção comercial de frutos, experimento I e II, $\mathrm{SP}, 2004$

\begin{tabular}{lccc}
\hline \multicolumn{1}{c}{ Média } & PT & PC & \% de FC \\
& \multicolumn{2}{c}{ (g/planta) } & \\
\hline Experimento I & 1136,8 & 770,7 & 67,8 \\
Experimento II & 3602,8 & 2110,4 & $58,6$. \\
\hline
\end{tabular}


Tabela 22. Médias do número total (NT) e comercial (NC) de frutos e porcentagem do número de frutos comerciais, experimento I e II, SP, 2004

\begin{tabular}{cccc}
\hline \multicolumn{1}{c}{ Média } & NT & NC & \% de NC \\
& \multicolumn{2}{c}{ (em gramas) } & \\
\hline Experimento I & 111,4 & 70,1 & 62,9 \\
Experimento II & 419,5 & 186,6 & 44,5 \\
\hline
\end{tabular}

Tabela 23. Médias de peso de frutos comerciais (FM) e do número de frutos por racemo (FR), experimento I e II, SP, 2004

\begin{tabular}{lll}
\hline \multicolumn{1}{c}{ Média } & FM & FR \\
\hline Experimento I & 76,9 & 4,7 \\
Experimento II & 70,7 & 5,1 \\
\hline
\end{tabular}

A produtividade do tomateiro é função direta do número de plantas por unidade de área, do número de frutos por planta (NC) e do peso médio dos frutos (FM) (Streck et al., 1998). A adoção de poda drástica é normalmente empregada no sistema convencional, para aumentar a qualidade dos frutos e concentrar a produção. Tal prática é associada a uma maior densidade de plantas, para que não ocorra perda de produtividade por área. Streck et al. (1998) sugerem, para essas condições, densidades de até 100.000 plantas por hectare.

Silva Junior et al. (1992), recomendam a poda drástica como mecanismo de escape contra a alta incidência de doenças e pragas. Por sua vez, Streck et al. (1998) concluíram que a adoção de poda drástica possibilita a redução do período de colheita do tomateiro de sete para quatro a cinco semanas em cultivo protegido. Resultados similares foram reportados por Gusmão (1998), onde a PD realizada acima do quarto racemo, possibilitou a retirada de $90 \%$ da produção total nas primeiras cinco semanas de colheita. No experimento I, provavelmente, pelas baixas temperaturas, o período de colheita estendeu-se por seis semanas, um pouco acima do observado por Streck et al. (1998). Porém, conforme Gusmão (1998), 90 \% da produção total se concentrou nas primeiras cinco semanas de colheita (Anexo J). 
No experimento I, a realização da poda drástica, parece ser mais uma medida fitossanitária, do que uma preocupação com a qualidade do fruto. Nesse caso, procura-se realizar a colheita no menor tempo possível, dificultando a reprodução da traça-do-tomateiro, a principal praga observada nos experimentos.

\subsubsection{Características do fruto}

\subsubsection{Classificação comercial dos frutos (CC)}

Os dois experimentos apresentaram a mesma porcentagem de frutos refugados $(30,7 \%)$. No entanto, o experimento I obteve uma tendência de produção de frutos maiores, com mais de $40 \%$ dos frutos classificados nas classes 50 e 60, de maior aceitação comercial, como observado por Poerschke et al. (1995), em plantas conduzidas com poda apical drástica.

É importante lembrar que na média dos valores do experimento II está incluso o híbrido Jane, que por ser do tipo caqui, produz frutos maiores que os outros cultivares testados, tipo Italiano e Santa cruz. Excluindo esse cultivar, o experimento II teria $32,6 \%$ de frutos na classe $0,38,6 \%$ na classe $40,24,4 \%$ na classe $50,4,3 \%$ na classe 60 e apenas $0,1 \%$ dos frutos na classe 70 .

Tabela 24. Porcentagem de frutos dentro das oito classes de diâmetro equatorial (em mm) no experimento I e II, SP, 2004

\begin{tabular}{ccccccccc}
\hline & \multicolumn{8}{c}{ Porcentagem de Frutos } \\
Média & $\mathbf{0}$ & $\mathbf{4 0}$ & $\mathbf{5 0}$ & $\mathbf{6 0}$ & $\mathbf{7 0}$ & $\mathbf{8 0}$ & $\mathbf{9 0}$ & $\mathbf{1 0 0}$ \\
\hline Experimento 1 & 30,7 & 27,5 & 28,5 & 12,1 & 1,2 & 0,0 & 0,0 & 0,0 \\
Experimento 2 & 30,7 & 35,5 & 24,8 & 7,0 & 1,75 & 0,25 & 0,0 & 0,0 \\
\hline
\end{tabular}

\subsubsection{Danos fitossanitários}

Ambos os experimentos obtiveram $22,3 \%$ de danos nos frutos causados por pragas. Todavia, no experimento I, os danos forma causados somente pela 
traça-do-tomateriro. Já, no experimento II, apesar da traça-do-tomateiro ter sido responsável por cerca de $17 \%$ de danos, ocorreram outras pragas que causaram, conjuntamente, danos significativos na produção.

Tabela 25. Porcentagem de danos causados nos frutos pelas pragas que ocorreram nos experimentos I e II, SP, 2004

\begin{tabular}{lccccc}
\hline & \multicolumn{5}{c}{ Danos nos frutos (\%) } \\
\multicolumn{1}{c}{ Média } & BGF & BPF & TRA & PER & Total \\
\hline Experimento I & 0,0 & 0,0 & 22,3 & 0,0 & 22,3 \\
Experimento II & 0,1 & 3,1 & 17,1 & 1,2 & 22,3 \\
\hline
\end{tabular}

Legenda: $\mathrm{BGF}=$ dano por broca-grande-do-fruto; $\mathrm{BPF}=$ dano por broca-pequena-do-fruto;

TRA= dano por traça-do-tomateiro e PER= dano por percevejo.

\subsubsection{Adaptação dos cultivares}

Como já foi mencionado, o sistema de condução adotado nos dois experimentos diferem em vários pontos relevantes. Tais diferenças ocasionam uma maior ou menor adaptação dos cultivares. Durante a realização dos experimentos, pôde-se perceber, que alguns cultivares comportaram-se melhor em um local do que em outro.

Entre os híbridos testados nos dois experimentos, o híbrido Sahel mostrou o melhor desempenho para rendimento comercial, e para outros componentes da produção avaliados. No entanto, no experimento I, também se destacaram os híbridos Colibri e Saladete DRW 3410, que não diferiram estatisticamente do Sahel.

Chama a atenção, o comportamento diferenciado dos cultivares de polinização livre (PL) nos dois experimentos. HTX - 5415 e San Marzano, que exibiram performances desapontadoras no experimento I, mostraram resultados satisfatórios no experimento II, superando estatisticamente, os híbrido Colib巨̄Ge HTX - 8027 em rendimento comercial.

De um modo geral, ficou evidente a superioridade dos híbridos frente aos cultivares de polinização livre. Os híbridos que apresentaram os melhores resultados foram superiores no experimento I (186 \%) e no experimento II (89 
$\%)$, as médias da melhor cultivar comum testada nos dois experimentos (HTX 5415).

As vantagens dos híbridos sobre as cultivares comuns são exaltadas sob diferentes aspectos. Em geral, o emprego de híbridos $F_{1}$, seja em sistemas orgânicos ou convencionais, proporciona aumentos potenciais na produção de 25 a 40 \%, maturação mais precoce, melhor uniformidade, maior vigor inicial e de desenvolvimento, melhor qualidade, resistência a doenças e capacidade de adaptação mais ampla (Melo, 1998).

Resultados de pesquisa obtidos por Bettiol et al. (2004), na região de Campinas, SP, indicaram que a variedade Santa Clara produziu apenas 23,5\% da produção obtida no sistema convencional, enquanto o híbrido Débora produziu 51,5\%, nas mesmas condições.

\subsubsection{Produção comercial}

As melhores médias de produção comercial, no experimento I, atingiram 1,3 kg/planta e no experimento II, 3,2 kg/planta. Com densidade de 20.000 plantas por hectare, utilizada nos dois experimentos, obtêm-se uma produtividade de 26 e 64 t/ha para o experimento I e II, respectivamente. A diferença de produtividade, e conseqüentemente, do retorno financeiro obtido entre os experimentos, se deve, principalmente, ao sistema de condução (poda drástica) adotada no experimento I. Conforme, Streck et al. (1998) comprovam em seus trabalhos, é possível obter uma produtividade do tomateiro com poda drástica, semelhante ao manejo de condução convencional, mediante o aumento da densidade de plantas. Com efeito, o produtor da área onde foi realizado o experimento I, já iniciou o plantio com densidades de 40 mil plantas por hectare, o que possibilitará, provavelmente, produções comerciais semelhantes às obtidas no experimento II.

É importante salientar que, a região onde o experimento II foi conduzido, apresenta características climáticas mais favoráveis ao desenvolvimento do 
tomateiro. Em Ibiúna, região onde foi instalado o experimento I, as condições são mais desfavoráveis ao crescimento e desenvolvimento do tomateiro, tendo este experimento, apesar de realizado a poda apical, um ciclo de produção de 140 dias, bem próximo ao do experimento II (138 dias), devido principalmente à baixa temperatura e a pouca insolação do período de realização do experimento. O período de colheita se estendeu por 6 semanas, no experimento I, com $80 \%$ da produção concentrada nas primeiras 5 semanas. No experimento II, o período de colheita ocorreu durante 7,5 semanas, e a produção colhida atingiu $80 \%$ da produção total apenas na sexta semana, o que comprova a eficiência da poda drástica como mecanismo de redução do período de colheita (Anexo K). 


\section{DISCUSSÃO}

No Brasil, não há estatística oficial disponível sobre a área plantada com tomate, em condições de campo e em cultivo protegido, e volume produzido em sistemas orgânicos. Como o sistema de informação é voltado para a agricultura convencional, faltam dados estatísticos para sistemas alternativos de produção. Embora, a olericultura orgânica, seja considerada, ainda, um nicho de mercado, o consumo de hortaliças e de outros produtos orgânicos encontra-se em franca expansão nos últimos anos.

Entre as oleráceas, o tomate para mesa é a que tem despertado maior interesse de cultivo em sistemas orgânicos, devido a diferentes fatores. Em primeiro lugar, trata-se de uma hortaliça de uso culinário versátil, cujo nível de consumo no país, nas formas in natura e industrializada, alcança $6,3 \mathrm{~kg} / \mathrm{ano}$ per capita (Melo, 2003). Segundo, o volume produzido organicamente é sempre menor que a demanda, não ocorrendo, portanto, as oscilações de preços freqüentes no tomate produzido convencionalmente. Isso, sem dúvida, representa um grande atrativo para os produtores, cujo número cresce a cada ano. Por último, o tomate de mesa, é uma hortaliça que têm estado em destaque na mídia sobre contaminações por resíduos de agrotóxicos, fato que tem contribuído para a queda de consumo do produto. Resultados de uma pesquisa de opinião sobre produtos orgânicos realizada, recentemente, na Escola Superior de Agricultura "Luiz de Queiroz", da Universidade de São Paulo, SP, revelaram que a motivação maior do consumidor na aquisição de alimentos orgânicos é a saúde; o fato de serem considerados livres de pesticidas representa uma característica muito importante (Borguini, 2002). 
Resultados de pesquisa similares realizadas em outros países indicaram também, que a questão da segurança alimentar, particularmente resíduo de pesticidas, constitui importante preocupação para os consumidores (Underhill \& Figueroa, 1996; Bordeleau et al, 2002).

Outra faceta das hortaliças orgânicas em geral, que enseja discussão, está relacionada aos preços dos produtos orgânicos, que chegam a custar mais de $100 \%$ em comparação com o similar convencional. Por conta disso, na atualidade, o universo de consumidores de alimentos orgânicos está limitado ao estrato da sociedade de maior poder aquisitivo e com melhor nível de instrução. Na pesquisa conduzida por Borguini (2002), junto aos consumidores, ficou claro que as maiores restrições ao consumo de alimentos orgânicos são os preços elevados e a disponibilidade limitada. Desse modo, a redução do diferencial de preço seria um importante instrumento para ampliar o acesso de maior parcela da população aos produtos orgânicos. Nessa pesquisa, a maior parte dos consumidores entrevistados declarou disposição para pagar um sobrepreço pelos produtos orgânicos. Numa pesquisa realizada na capital paulista por Cerveira \& Castro (1999), ficou evidente que o consumidor aceita pagar até 30 \% a mais pelo produto orgânico.

O rendimento do tomate de mesa produzido por via orgânica é, em geral, inferior ao tomate cultivado convencionalmente. Ocorre que, são praticamente inexistentes no país informações técnicas sobre diferentes aspectos de manejos alternativos de cultivo de hortaliças, uma vez que o sistema nacional de pesquisa, contempla, quase que exclusivamente, a agricultura convencional. Os produtores orgânicos não dispõem de informações sobre a adaptação de cultivares às condições agroecológicas da área onde serão plantados, bem como relativos aos diferentes aspectos fitotécnicos da cultura e ao manejo de pragas e doenças. É comum, os produtores ficarem a mercê de consultores que, muitas vezes, não tem a devida qualificação para atuarem como tal. Portanto, urge que as instituições de ensino e pesquisa oficiais implementem programas de pesquisa voltados para sistemas alternativos de agricultura, 
gerando conhecimento e tecnologias que possam ser transferidas eficientemente para o setor produtivo e, dessa forma, propiciar ganhos de qualidade e redução de custos de produção. Com isso, o mercado consumidor poderia ser ampliado, pois teria condições de adquirir os produtos orgânicos por preço compatível com o seu padrão de renda.

A questão variedade comum versus híbrido de primeira geração $\left(F_{1}\right)$ sempre suscitou polêmica no ambiente da agricultura orgânica. No caso específico do tomate, a crença que variedades comuns, rústicas e, portanto, menos demandantes de insumos modernos, poderiam mostrar melhor desempenho em manejo orgânico que os híbridos, não se sustenta mais hoje em dia. O que se constata é que a grande maioria dos produtores de tomate orgânico usa sementes híbridas com alto potencial produtivo e com resistência múltipla a doenças e desordens fisiogenéticas limitantes. É o caso dos produtores Marcelo Saito e Marcelo Oyafuso, onde o presente trabalho foi conduzido, que plantam os híbridos Saladete DRW 3410 e Jane, respectivamente. Outros produtores profissionais de tomate orgânico do estado de São Paulo, como Fernando Ataliba, do Sítio Catavento, Itupeva, SP e Érika Tanuri, Araraquara, SP, também usam sementes híbridas em seus cultivos. No município de Nova Prata do Iguaçu, PR, o produtor de tomate orgânico, Wilson Cardoso, planta o híbrido Styllus, que é resistente às estirpes de geminivírus incidentes no Brasil. O produtor reporta que consegue produzir com esse híbrido, do tipo salada, 5 a $6 \mathrm{~kg} /$ planta de frutos comerciais, sendo uma excelente produção para o sistema orgânico (Noticeres, 2004).

O fato de o tomateiro ser afetado por inúmeras doenças, faz com que a resistência genética, seja mais importante no cultivo orgânico que no convencional, onde os produtores têm mais opções de controle. Por isso, Diver et al. (1999) consideram a incidência de doenças e pragas o calcanhar de Aquiles da produção orgânica de tomate, nos Estados Unidos. Há de se admitir, que na vasta maioria dos casos as culturas, sobretudo a do tomate, estão sob 
permanente pressão de pragas e doenças; nessas condições, o uso de híbridos pode constituir numa arma estratégica dentro do manejo integrado.

Os poucos resultados de pesquisa disponíveis no Brasil mostram que, em sistemas orgânicos de tomate, as variedades comuns têm produtividade inferior à dos híbridos.

No presente trabalho, cujos experimentos foram conduzidos em duas regiões do estado de São Paulo climaticamente distintas e sob manejos orgânicos diferenciados, ficou evidente a superioridade dos híbridos sobre as variedades comuns testadas, quanto à produção comercial e aos demais parâmetros avaliados.

O mercado de alimentos orgânicos, incluindo o tomate e outras hortaliças, é altamente promissor. Todavia, o setor produtivo enfrenta gargalos e desafios, sobretudo, ligados aos sistemas de manejo em uso que poderiam ser solucionados com a ampliação de ações de pesquisas nessa área. É preciso também que as tecnologias a ser desenvolvidas, sejam eficientemente transferidas ao setor produtivo. Isso só será concretizado na medida em que os agentes de extensão rural e assistência técnica tornem-se devidamente capacitados. Com isso, deverá ocorrer a redução de custos de produção e o aumento da oferta, tornando os produtos mais acessíveis a um contingente maior de consumidores. 


\section{CONCLUSÕES}

Considerando as condições em que os experimentos foram desenvolvidos, os resultados permitem concluir:

10 híbrido Sahel mostrou o melhor desempenho para rendimento comercial, e para outros componentes da produção nos dois sistemas de condução ao qual foi submetido. No experimento I, destacaram-se, ainda, os híbridos Colibri e Saladete DRW 3410, que não diferiram estatisticamente de 'Sahel'.

2 Os híbridos, de um modo geral, mostraram melhor desempenho que os cultivares de polinização livre.

3 Dos híbridos avaliados, apenas "Sahel" mostrou maior amplitude adaptativa.

4 No experimento I, conduzido com poda apical drástica, a porcentagem de frutos de melhor cotação comercial foi maior do que no experimento II, sem poda apical.

5 No experimento I, o período de colheita foi menor e mais concentrado do que no experimento II.

6 A traça-do-tomateiro revelou-se como fator limitante, afetando significativamente o rendimento comercial. 
ANEXOS 


\section{Anexo A}

INSTITUTO NACIONAL DE METEOROLOGIA TEMPERATURAS DIÁRIAS

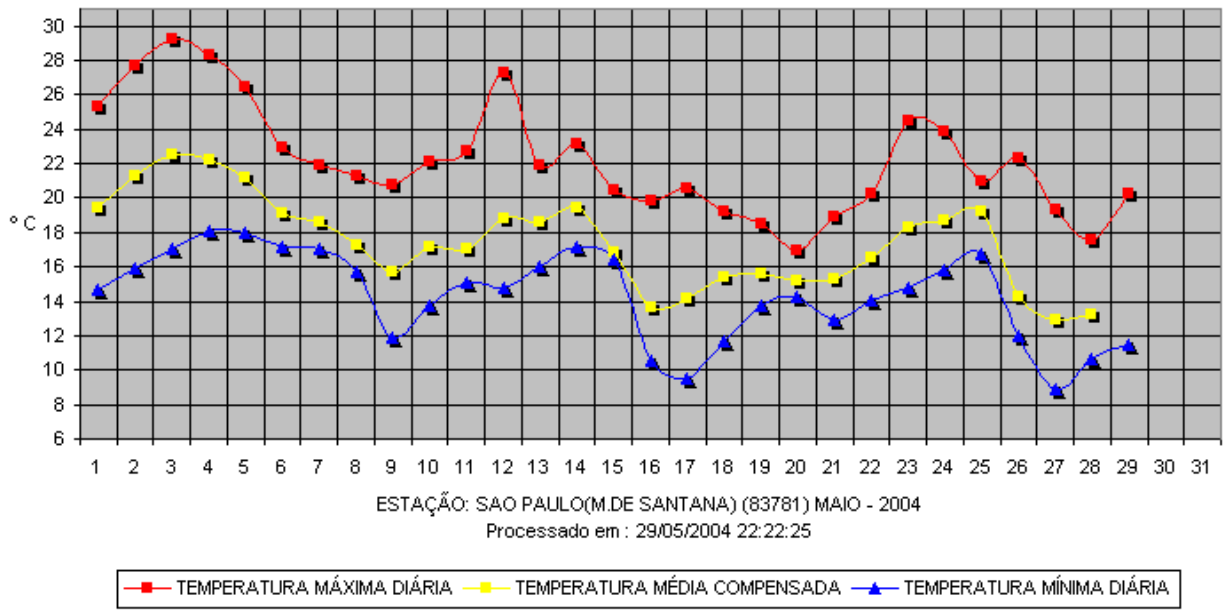

Figura 1. Temperatura máxima diária, média compensada e mínima diária para o mês de maio de 2004, São Paulo-SP.

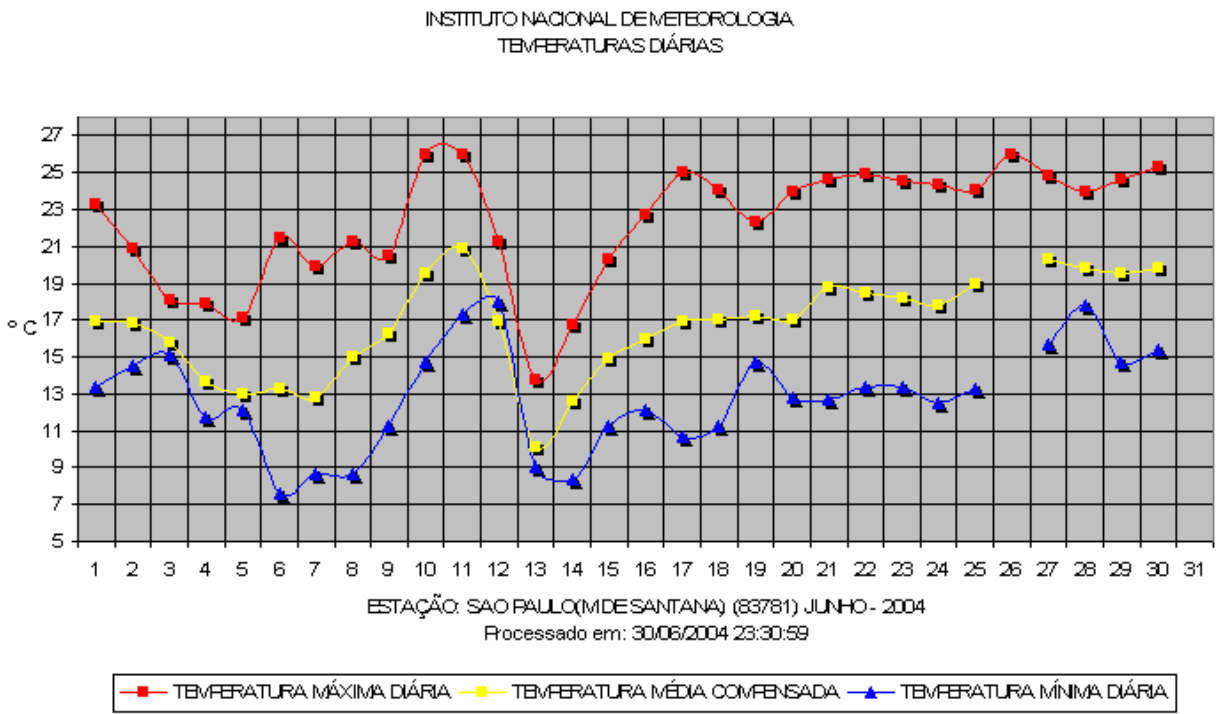

Figura 2. Temperatura máxima diária, média compensada e mínima diária para o mês de junho de 2004, São Paulo-SP 


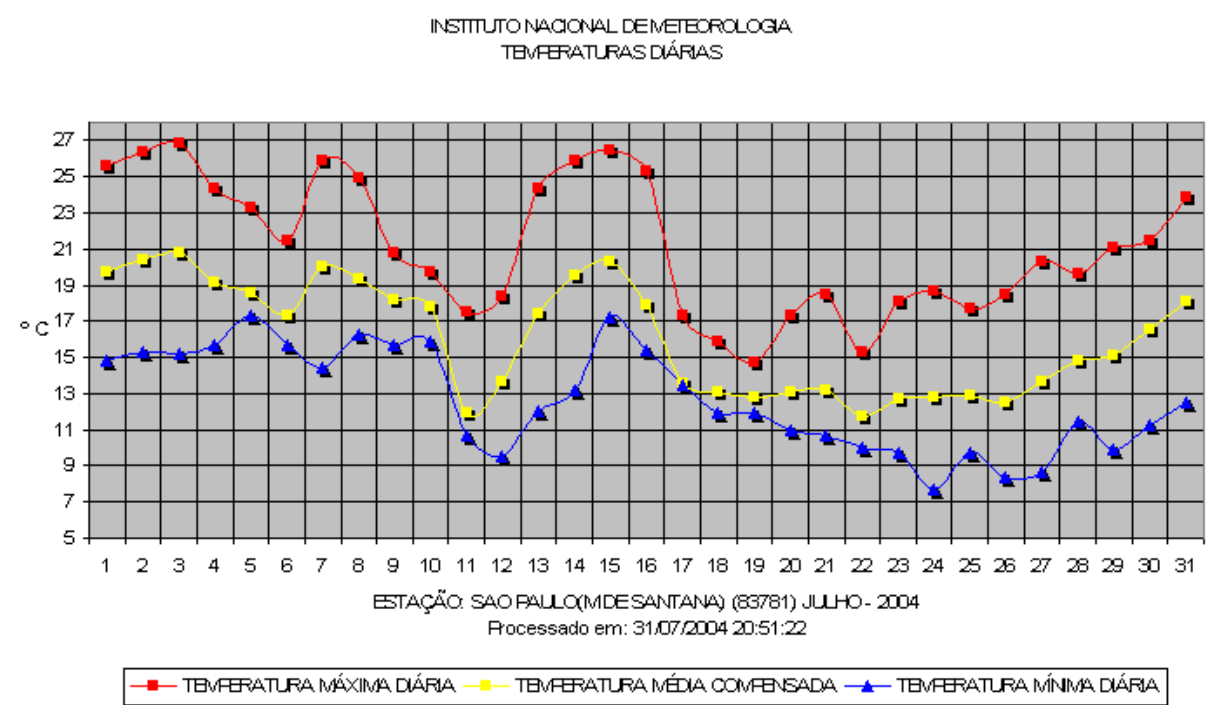

Figura 3. Temperatura máxima diária, média compensada e mínima diária para o mês de julho de 2004, São Paulo-SP

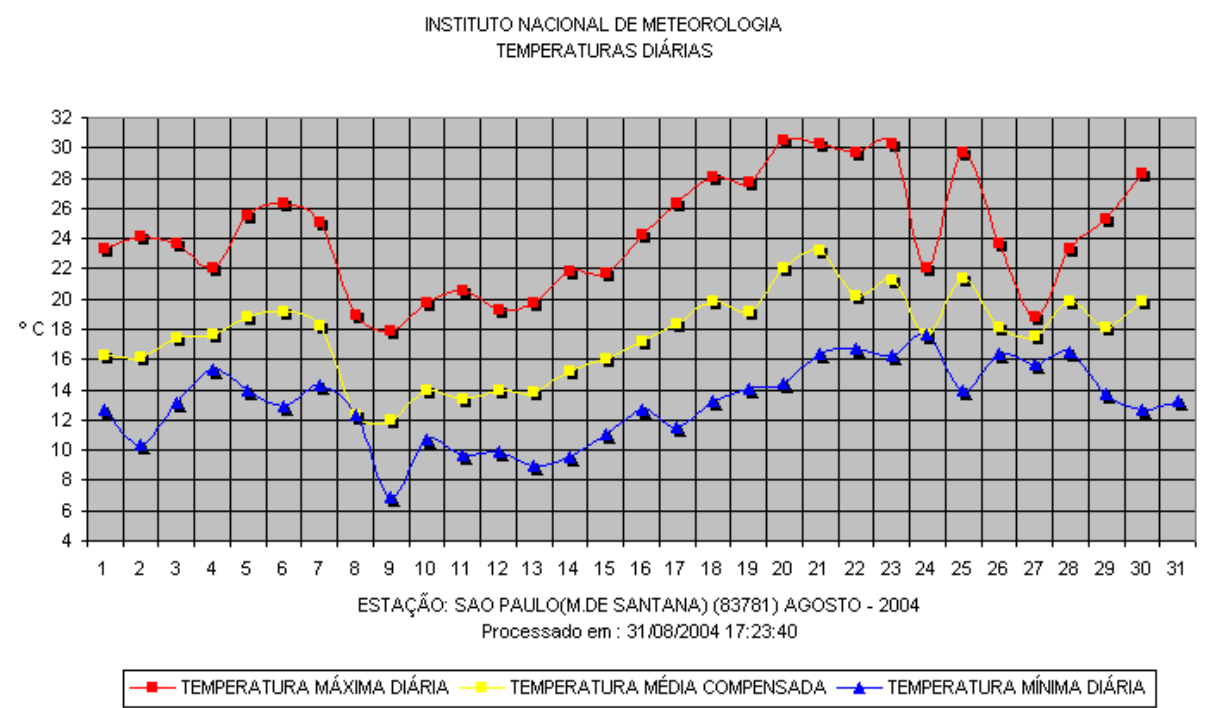

Figura 4. Temperatura máxima diária, média compensada e mínima diária para o mês de agosto de 2004, São Paulo-SP 
INSTITIONACOONAL DEMETEOROLOGA TEMFRATLRASDÁAAS

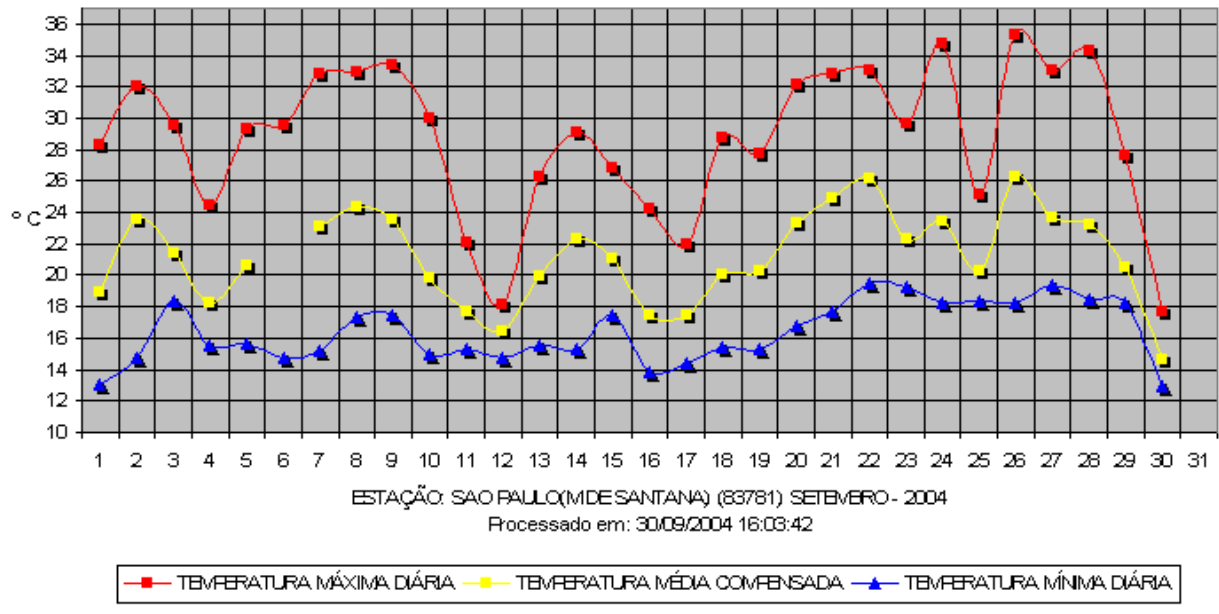

Figura 5. Temperatura máxima diária, média compensada e mínima diária para o mês de setembro de 2004, São Paulo-SP 


\section{Anexo B}

Cronograma das atividades realizadas na cultura do tomate no experimento I, Ibiúna-SP, 2004.

\begin{tabular}{|c|c|c|}
\hline Data & Atividade & Motivo \\
\hline Abril/04 & Semeadura nas bandejas & \\
\hline $27 / 05 / 04$ & Transplantio & \\
\hline 02/09/04 & $1^{\mathrm{a}}$ Colheita & \\
\hline 08/09/04 & $2^{\mathrm{a}}$ Colheita & \\
\hline 16/09/04 & $3^{\mathrm{a}}$ Colheita & \\
\hline 23/09/04 & $4^{a}$ Colheita & \\
\hline 30/09/04 & $5^{\mathrm{a}}$ Colheita & \\
\hline 07/10/04 & $6^{\mathrm{a}}$ Colheita & \\
\hline $14 / 10 / 04$ & $7^{\mathrm{a}}$ Colheita & \\
\hline Semanalmente & $\begin{array}{l}\text { Pulverização: Adubo foliar arbore CAB2 } \\
(100 \mathrm{ml})+\text { Bac-Control WP }(100 \mathrm{~g})+\text { Rocksil } \\
(100 \mathrm{~g})+\text { Sulfato de Zinco }(30 \mathrm{~g})+\text { Sulfato } \\
\text { de Manganês }(30 \mathrm{~g}) \text {. }\end{array}$ & $\begin{array}{l}\text { Adubação foliar, } \\
\text { controle } \\
\text { biológico, } \\
\text { controle } \\
\text { fungos. }\end{array}$ \\
\hline Semanalmente & $\begin{array}{l}\text { Pulverização: Kumulus }(100 \mathrm{~g})+\text { Biocontrol } \\
(100 \mathrm{ml})+\text { Adubo foliar arbore CAB2 } \\
(100 \mathrm{ml}) .\end{array}$ & $\begin{array}{l}\text { Controle do } \\
\text { micro-ácaro e } \\
\text { adubação foliar }\end{array}$ \\
\hline Eventualmente & Pulverização: Natural óleo & $\begin{array}{l}\text { Controle mosca- } \\
\text { branca }\end{array}$ \\
\hline
\end{tabular}




\section{Anexo C}

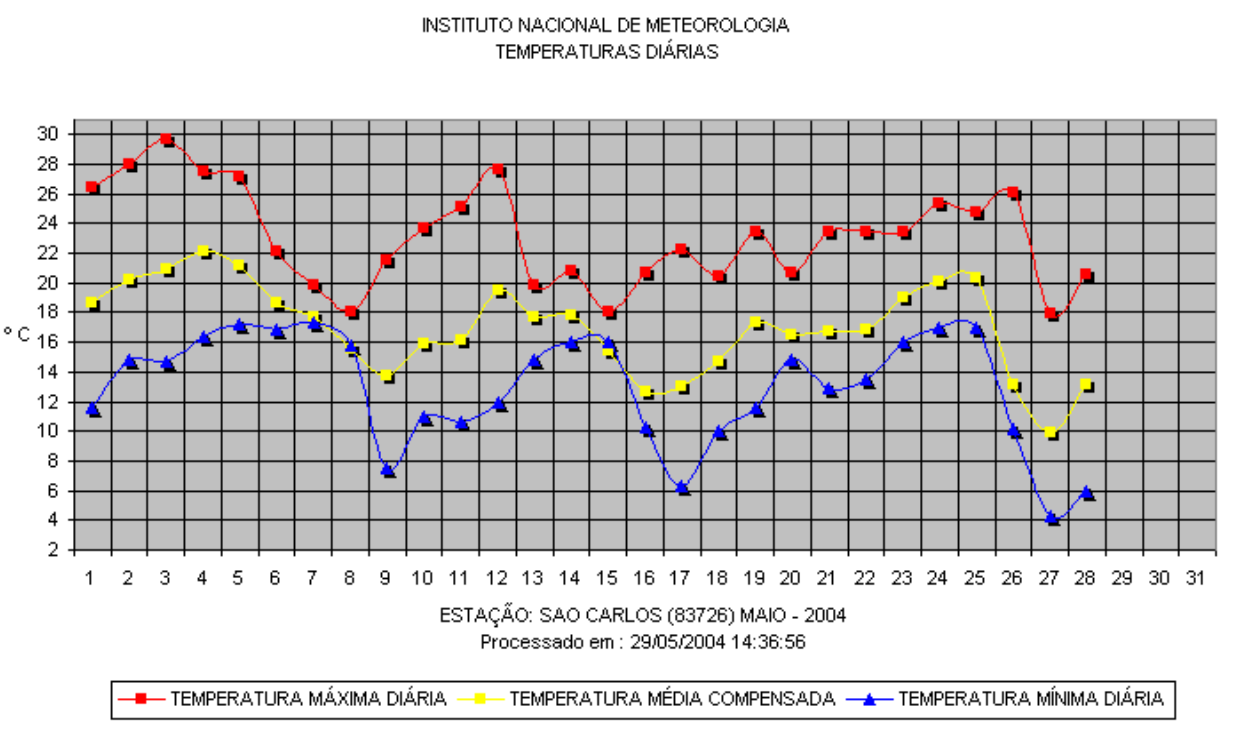

Figura 7. Temperatura máxima diária, média compensada e mínima diária para o mês de maio de 2004, São Carlos-SP

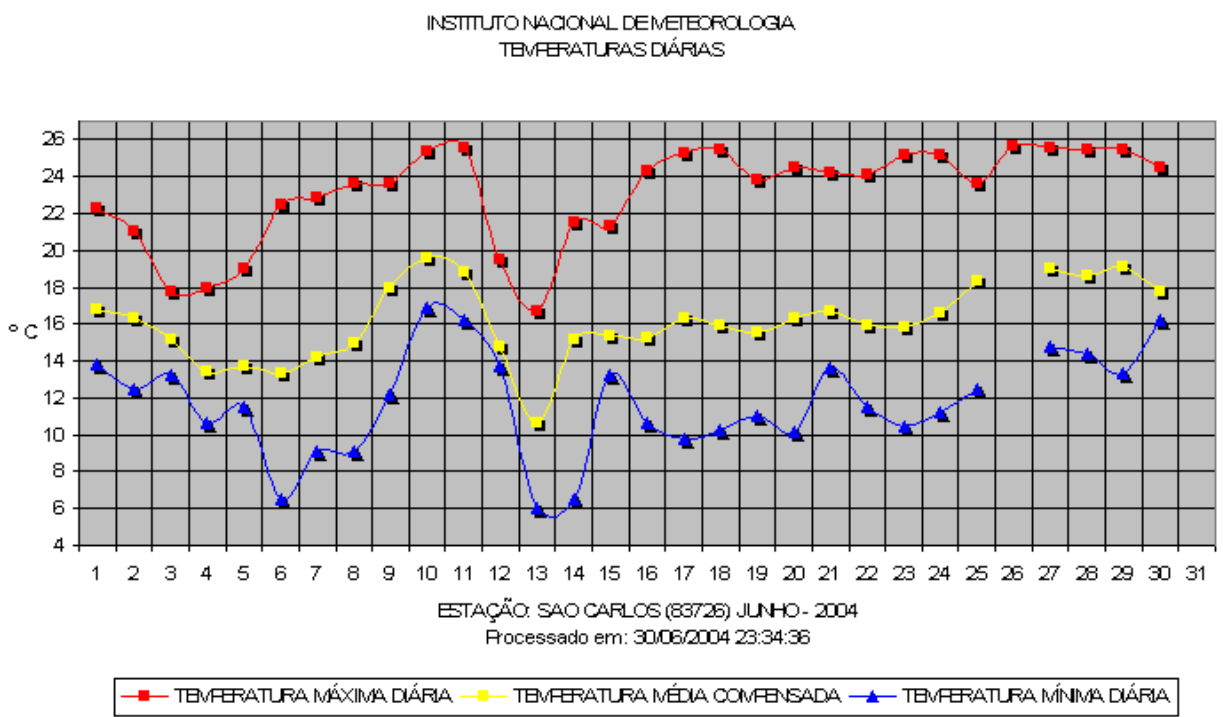

Figura 8. Temperatura máxima diária, média compensada e mínima diária para o mês de junho de 2004, São Carlos-SP 


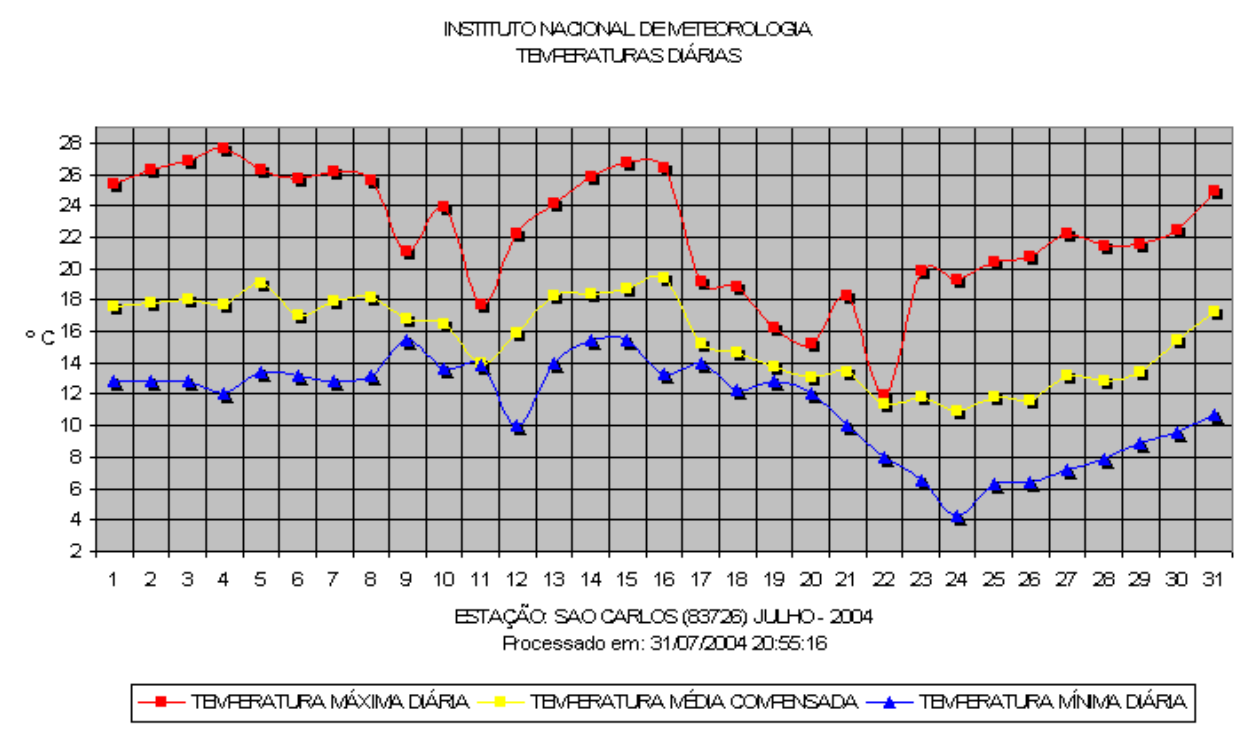

Figura 9. Temperatura máxima diária, média compensada e mínima diária para o mês de Julho de 2004, São Carlos-SP

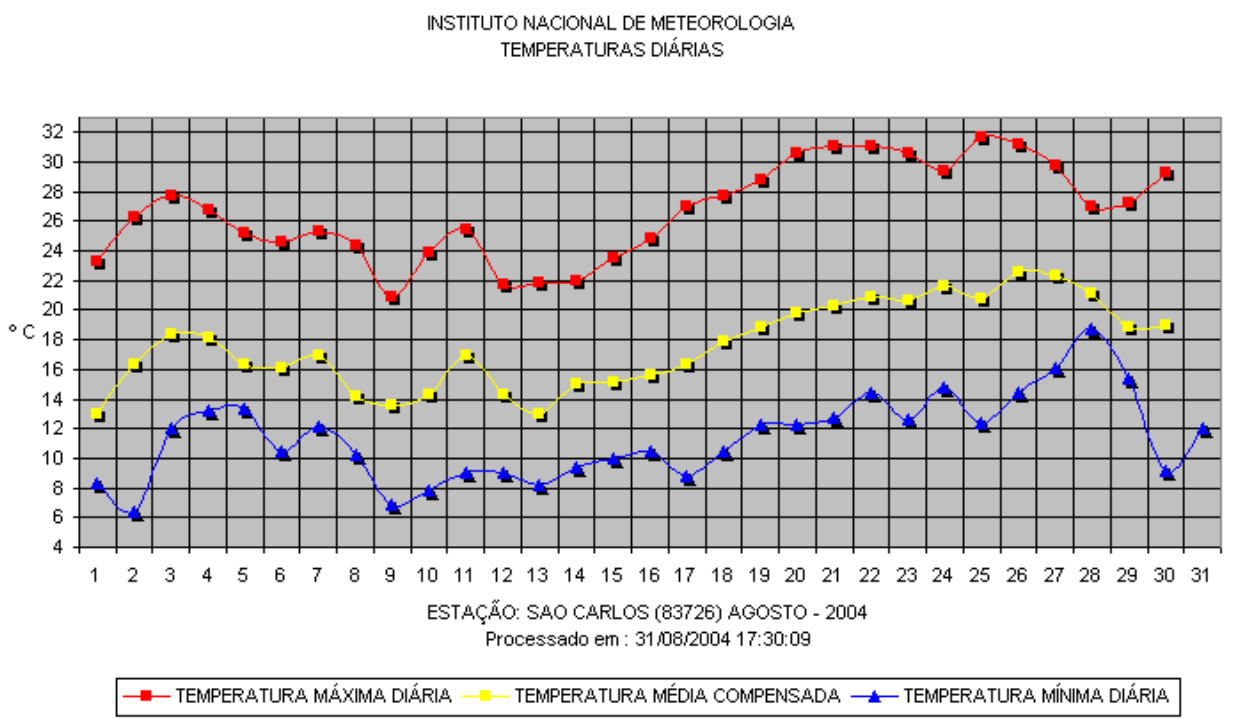

Figura 10. Temperatura máxima diária, média compensada e mínima diária para o mês de agosto de 2004, São Carlos-SP 
INSTITIONACONAL DEMEIEOROLOGA TEMERATLRASDÁAAAS

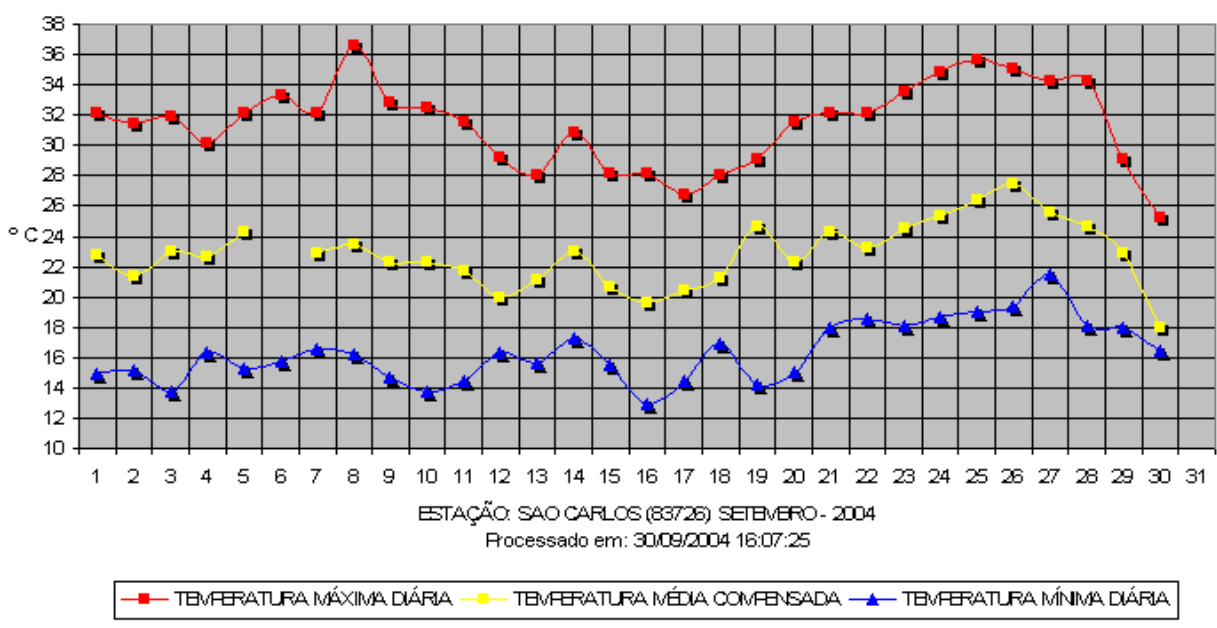

Figura 11. Temperatura máxima diária, média compensada e mínima diária para o mês de setembro de 2004, São Carlos-SP 


\section{Anexo D}

Cronograma do manejo realizado no tomate no experimento II, Araraquara-SP, 2004.

\begin{tabular}{|c|c|c|}
\hline Data & Atividade & Motivo \\
\hline $01 / 05$ & Preparo de solo & \\
\hline $14 / 05$ & Semeadura & \\
\hline $21 / 05$ & Emergência das plântulas & \\
\hline $18 / 06$ & Transplante das mudas & \\
\hline $19 / 07$ & $\begin{array}{l}\text { Aplicação de cal com sulfato de } \\
\text { cobre* }^{*}\end{array}$ & $\begin{array}{l}\text { Incidência da requeima } \\
\text { devido á um período chuvoso }\end{array}$ \\
\hline $30 / 07$ & $\begin{array}{l}\text { Aplicação de cal com sulfato de } \\
\text { cobre* }^{*}\end{array}$ & e frio \\
\hline 03/08 & Aplicação de DIPEL (BT)** & $\begin{array}{l}\text { Controle da broca-pequena- } \\
\text { do-fruto }\end{array}$ \\
\hline 04/08 & Aplicação de SUPERMAGRO*** & \\
\hline 11/08 & Aplicação de DIPEL (BT)** & \\
\hline 23/08 & Aplicação de DIPEL (BT) ${ }^{\star \star}$ & \\
\hline $26 / 08$ & Aplicação de enxofre (KUMULUS) ${ }^{\star \star \star *}$ & $\begin{array}{l}\text { Controle microácaro (ac. } \\
\text { vermiforme) }\end{array}$ \\
\hline 28/08 & Aplicação de SUPERMAGRO**** & \\
\hline 10/09 & Aplicação de enxofre (KUMULUS) ${ }^{\star \star \star \star ~}$ & \\
\hline 15/09 & $1^{a}$ colheita do experimento & \\
\hline $21 / 09$ & $2^{\mathrm{a}}$ colheita do experimento & \\
\hline $24 / 09$ & $3^{a}$ colheita do experimento & \\
\hline 28/09 & $4^{\mathrm{a}}$ colheita do experimento & \\
\hline $01 / 10$ & $5^{\mathrm{a}}$ colheita do experimento & \\
\hline $5 / 10$ & $6^{\mathrm{a}}$ colheita do experimento & \\
\hline $13 / 10$ & $7^{\mathrm{a}}$ colheita do experimento & \\
\hline $15 / 10$ & $8^{\mathrm{a}}$ colheita do experimento & \\
\hline $20 / 10$ & $9^{a}$ colheita do experimento & \\
\hline $22 / 10$ & $10^{a}$ colheita do experimento & \\
\hline $19 / 10$ & $11^{\mathrm{a}}$ colheita do experimento & \\
\hline 3/11 & $12^{\mathrm{a}}$ colheita do experimento & \\
\hline \multicolumn{3}{|c|}{ 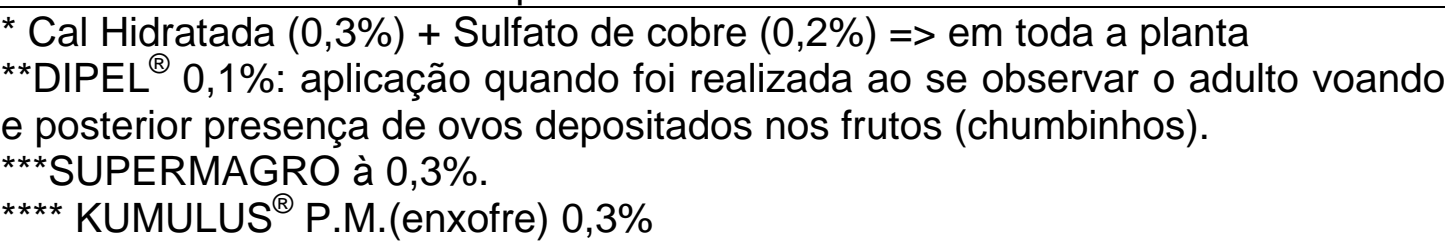 } \\
\hline
\end{tabular}




\section{Anexo E}
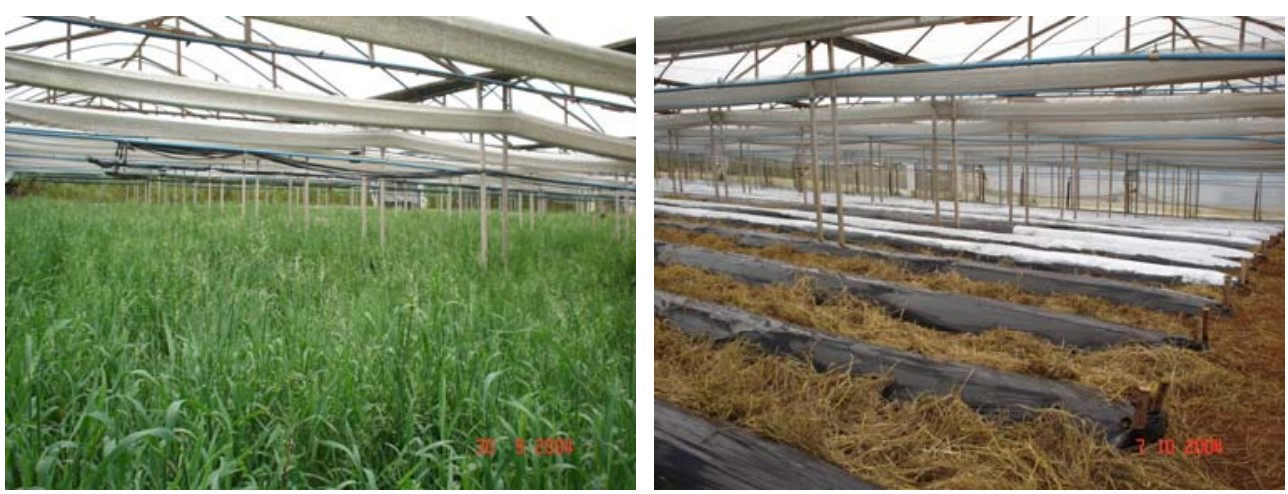

Fig. 1 - Plantio de Aveia preta

Fig. 2 - Canteiro preparado para o plantio
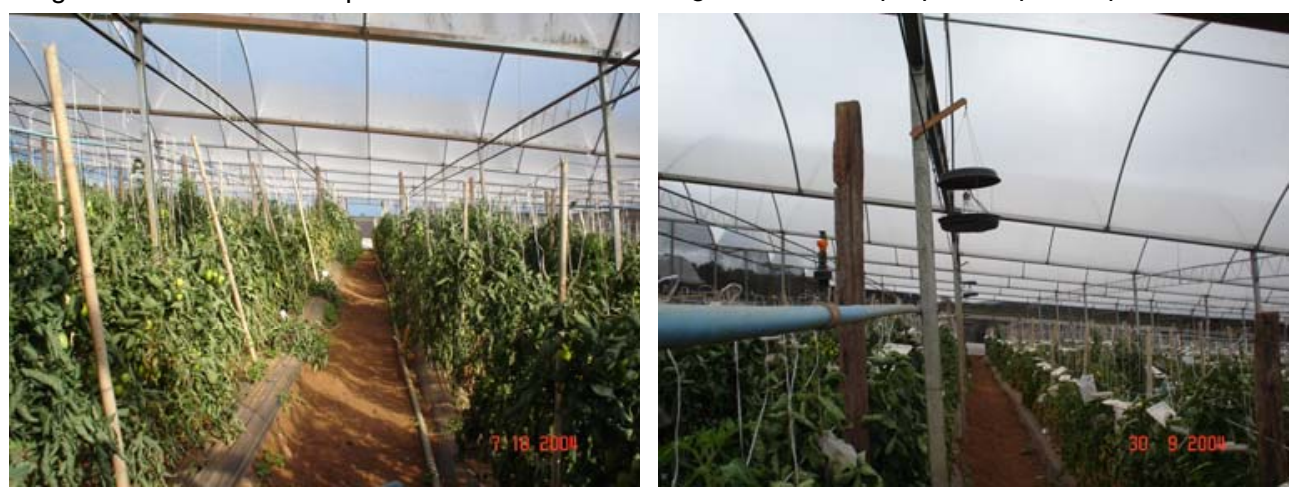

Fig. 3 - Visão geral do experimento I

Fig. 4 - Armadilhas luminosas 

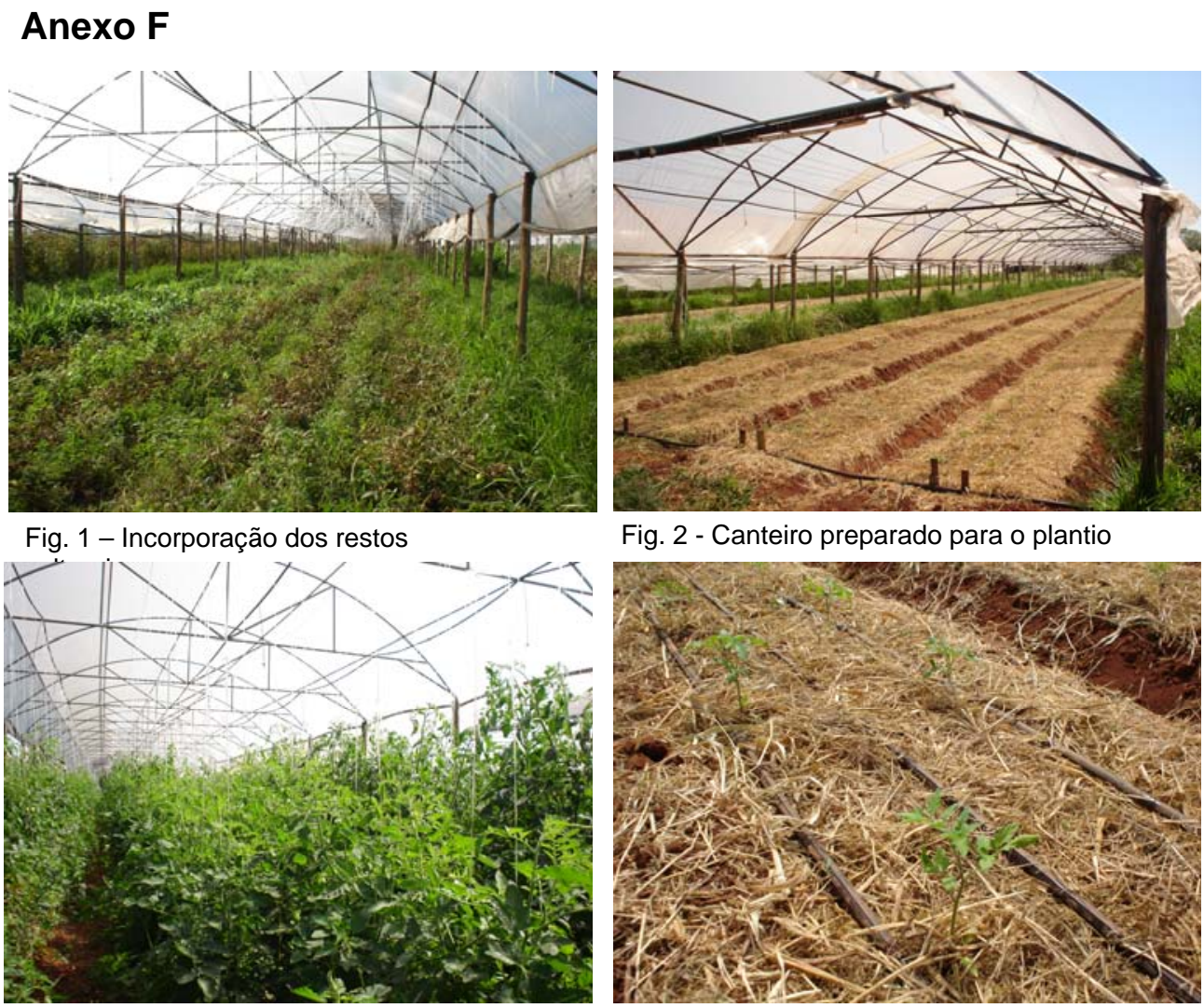

Fig. 2 - Canteiro preparado para o plantio

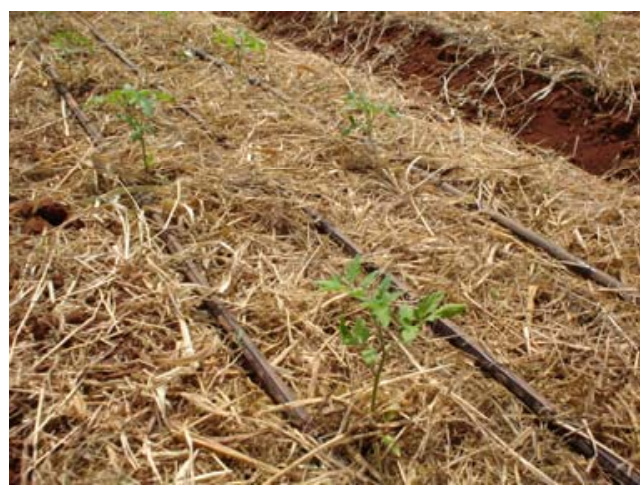

Fig. 3 - Visão geral do experimento II

Fig. 4 - Sistema de irrigação (Gotejo) 
Anexo G
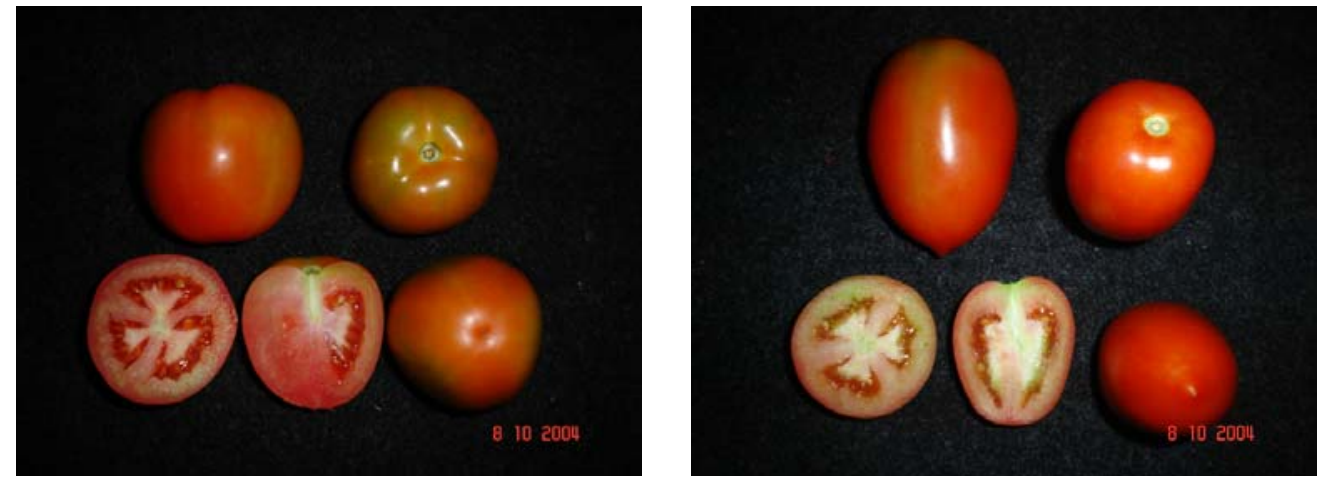

Avalon

Colibri
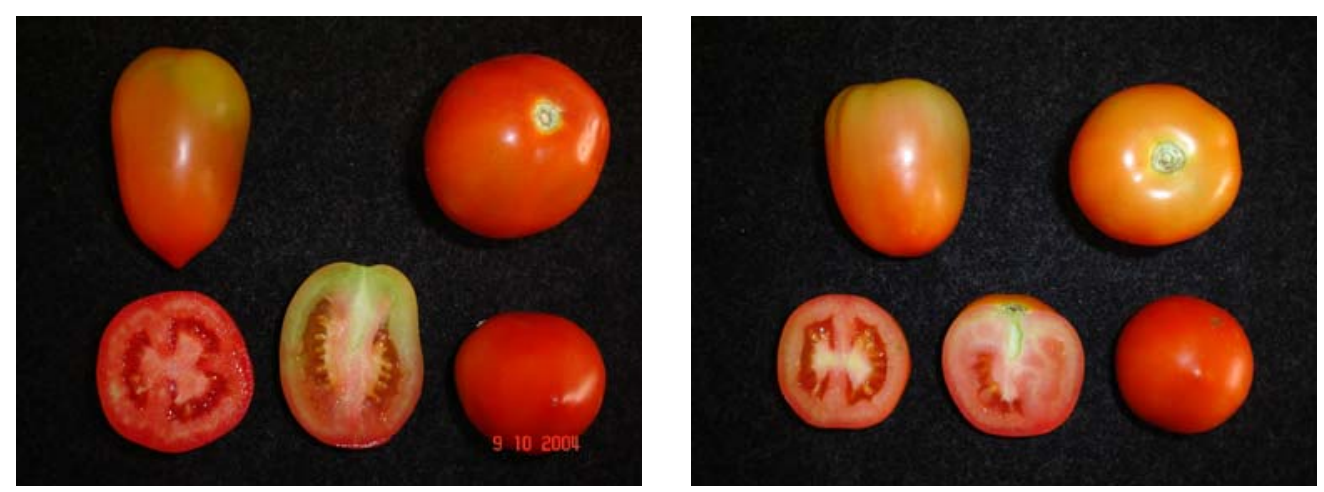

HTX - 5415

HTX - 8027

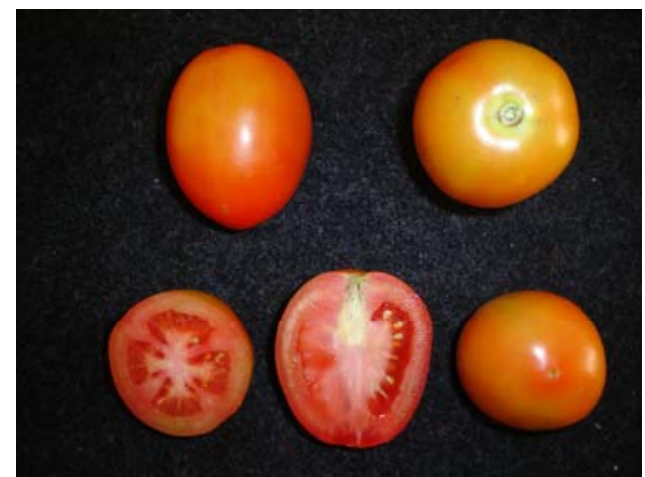

Sahel

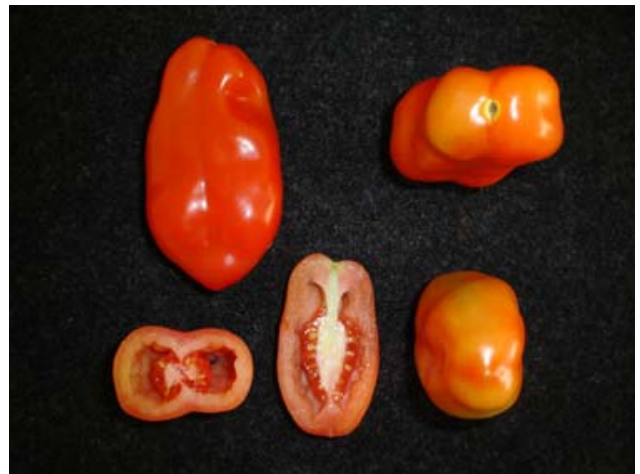

San Marzano 

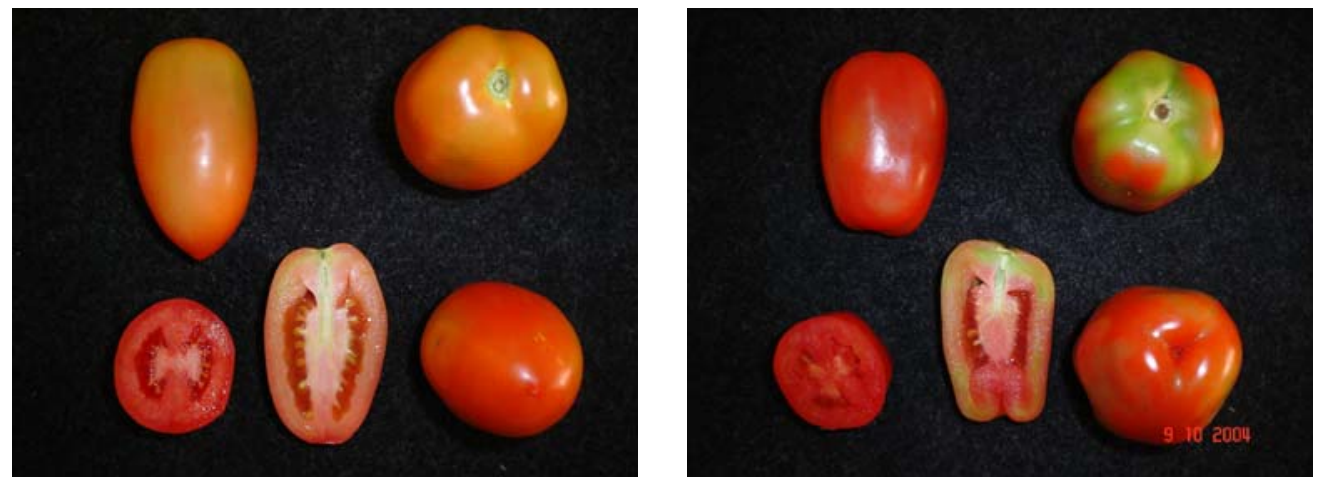

San Vito

$$
\text { Júpiter }
$$

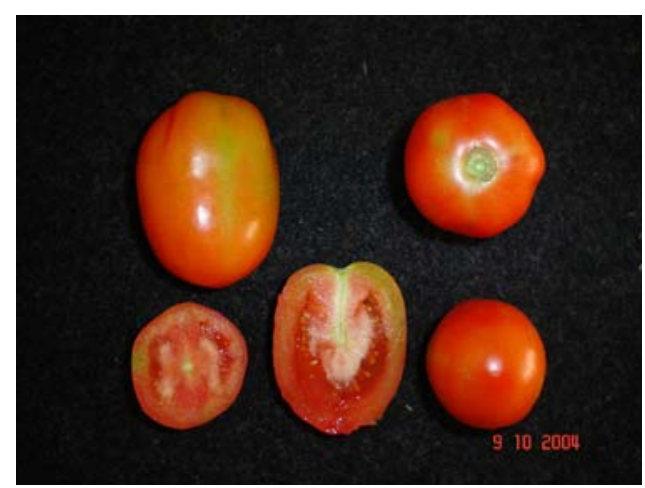

Raminho

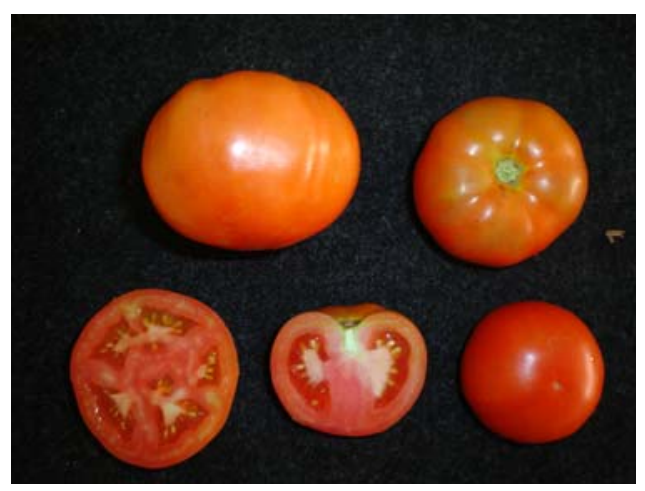

Jane 


\section{Anexo H}

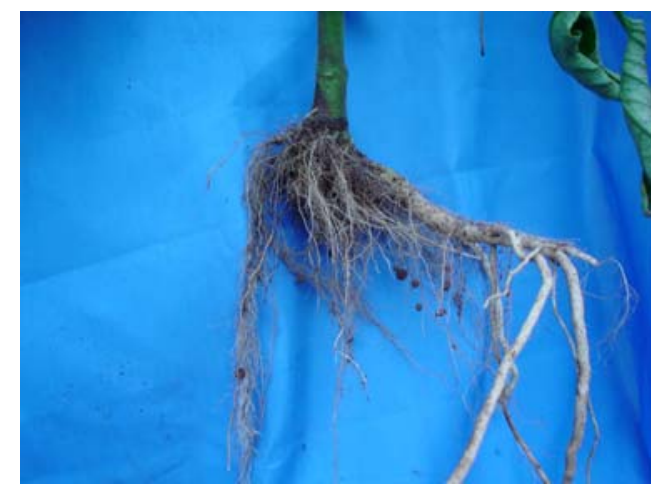

Fig. 1 - Nível de infestação de 0 \%.
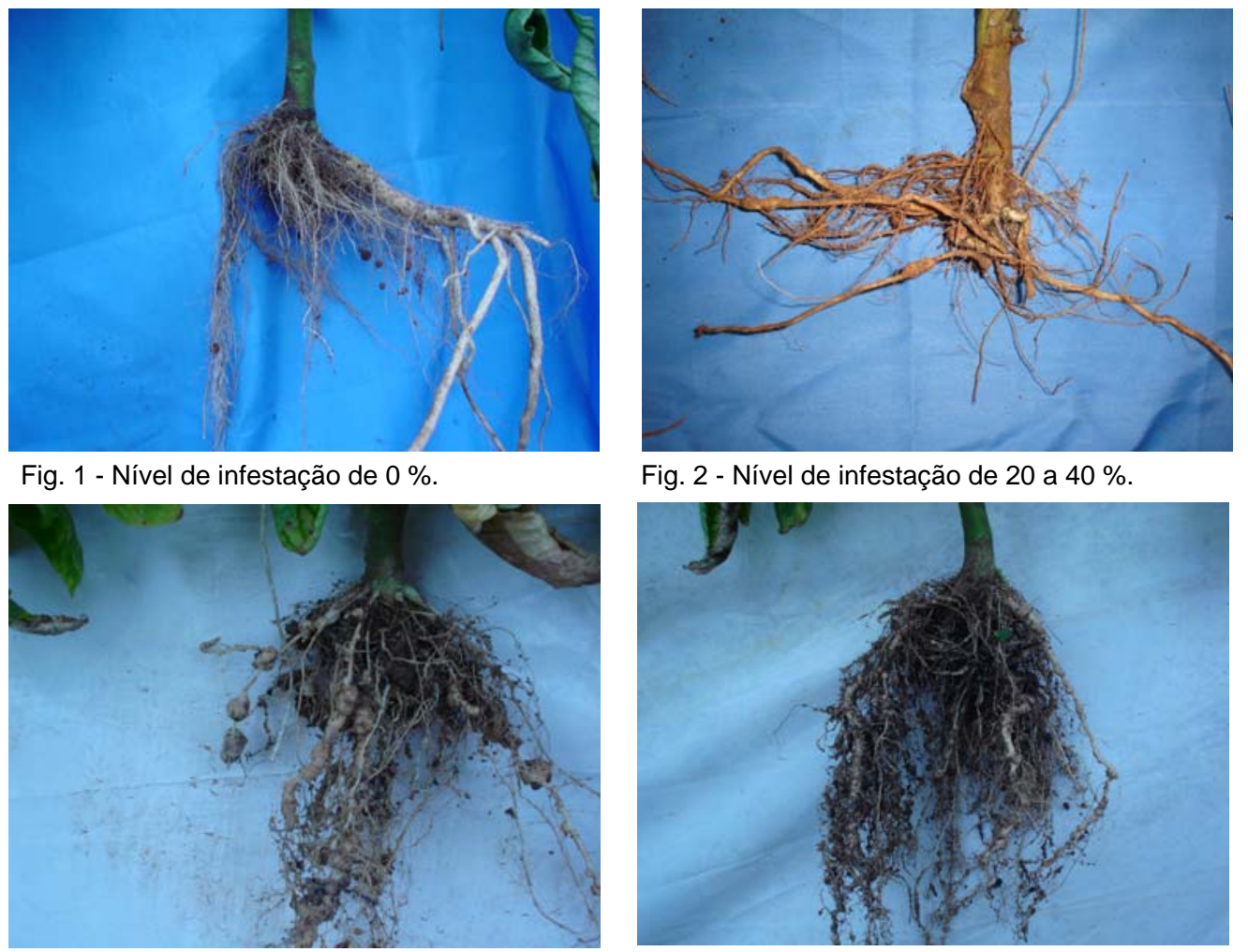

Fig. 2 - Nível de infestação de 20 a 40 \%.

Fig. 2 - Nível de infestação de 60 a 80 \%.

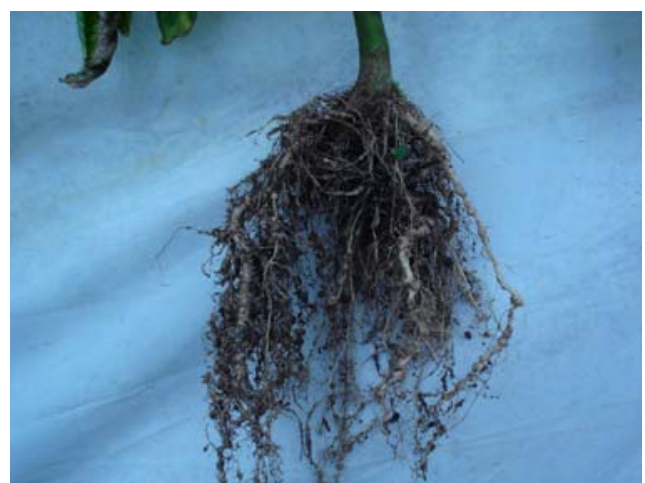

Fig. 3 - Nível de infestação de 80 a $100 \%$. 


\section{Anexo I}
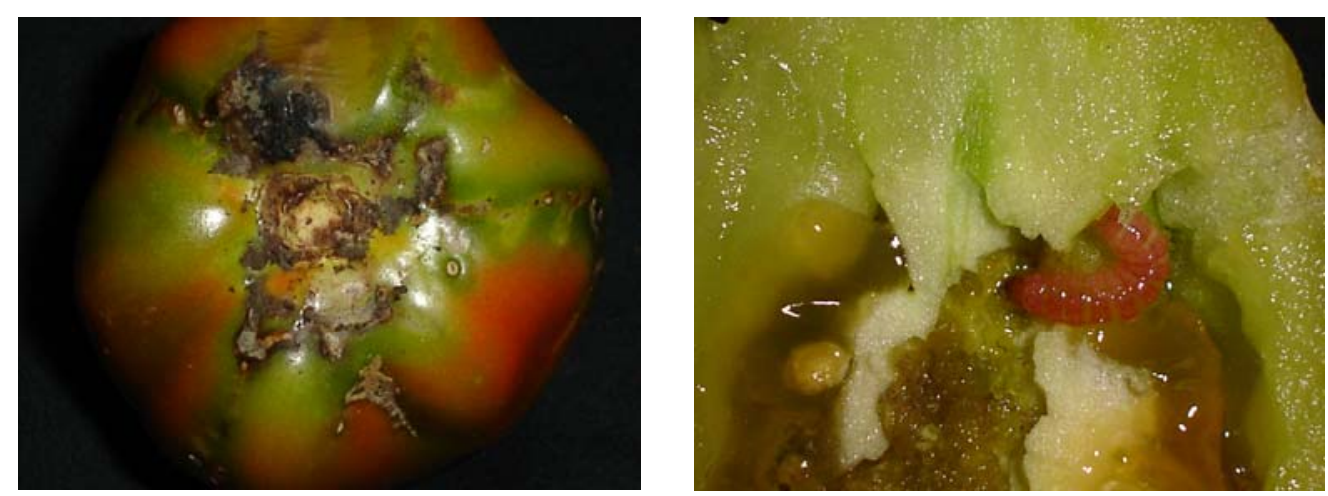

Fig. 1 - Fruto com dano de traça

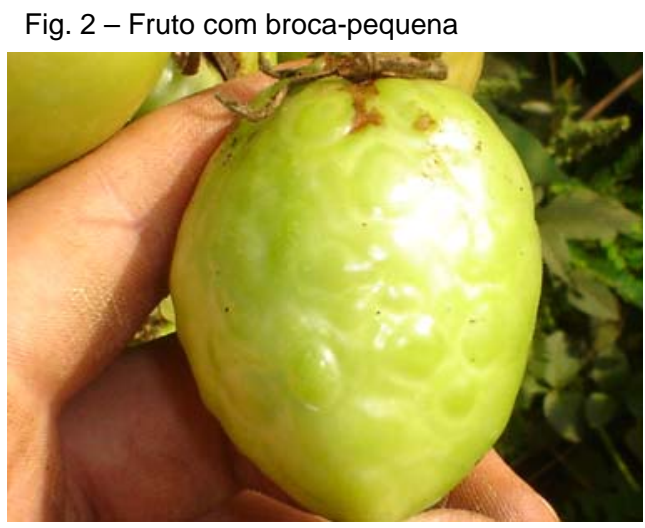

Fig. 3 - Dano causado por percevejo

Fig. 4 - Sintomas do ataque de vira-cabeça 


\section{Anexo J}

\section{Produção acumulada}

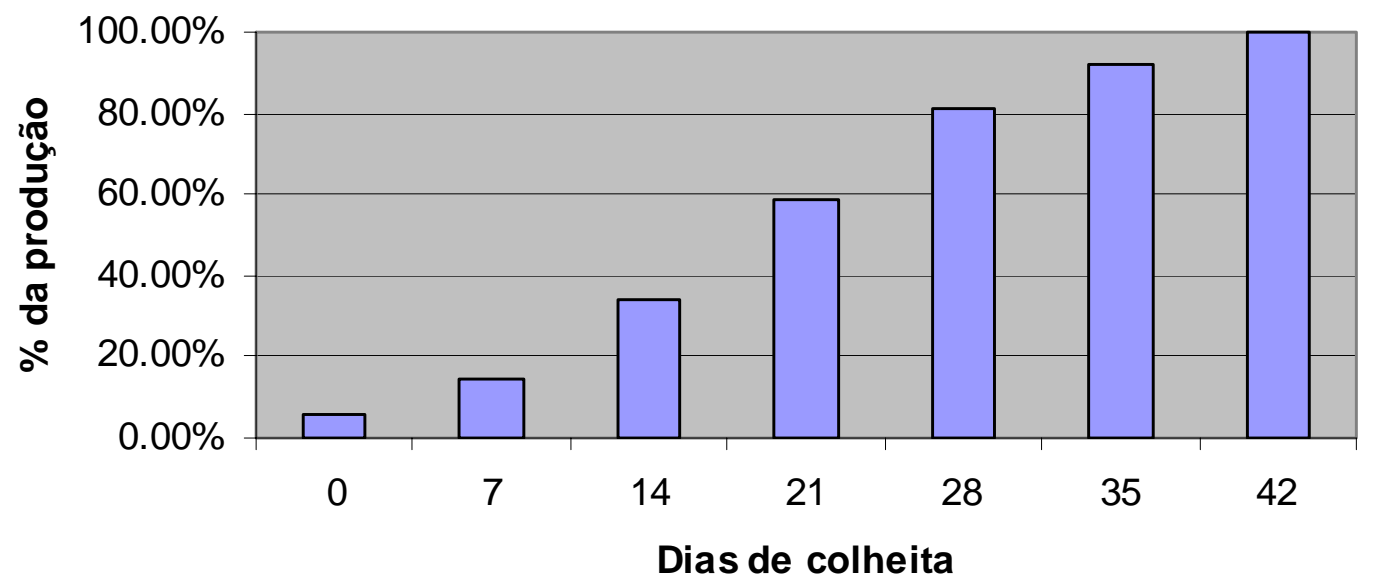

Produção acumulada (\%) por dia de colheita, experimento I, Ibiúna, SP

\section{Produção acumulada}

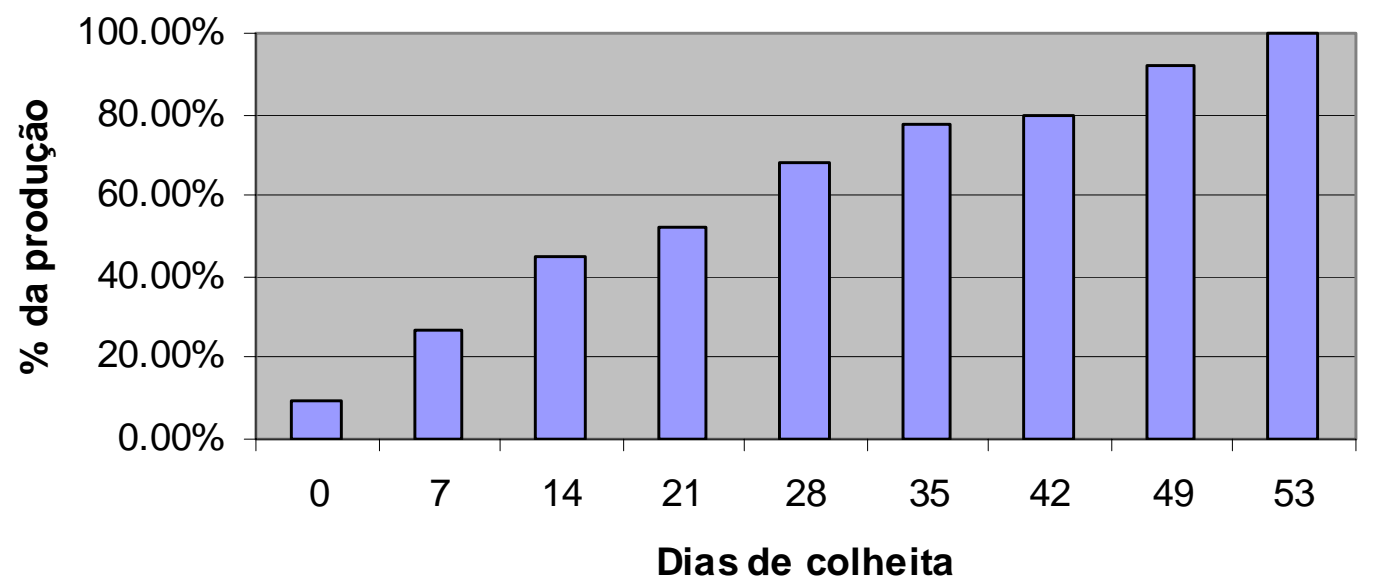

Produção acumulada (\%) por dia de colheita, experimento II, Araraquara, SP 


\section{REFERÊNCIAS BIBLIOGRÁFICAS}

Agência Nacional de Vigilância Sanitária (ANVISA). www.anvisa.gov.br/toxicologia/residuos/rel anual 2003.pdf , (10 mar. 2005).

ALVARENGA, M. A. R. Sistemas de produção em campo aberto e em ambiente protegido. In: ALVARENGA, M. A. R. Tomate: produção em campo, em casa de vegetação e em hidroponia. Lavras: Ed. UFLA, 2004. p.160-190.

ASP, N. G. et all. Rapid enzymatic assayu of insoluble and soluble dietary fiber. Journal of Agricultural and Food Chemistry. v.31, n.3, p.476-482, 1983.

ASSOCIATION OF OFFICIAL ANALYTICAL CHEMISTS. Official methods of analysis of the association of Official Analytical Chemists. 16 ed. Washington: AOAC, 1995. 2v.

AUBERT, C. Palestra: Engenheiro Agrônomo Claude Aubert. In: ENCONTRO BRASILEIRO DE AGRICULTURA ALTERNATIVA, 1., Curitiba, 1981. Anais. Curitiba: Federação dos Engenheiros Agrônomos do Brasil/Associação dos Engenheiros Agrônomos do Paraná, 1981. 161-190. 
BELFORT, C. C.; CAMPOS, J. P.; CASALI, V. W. D.; GALVÃO, J. D.; CARDOSO, A. A. Efeito de poda da haste principal e população de plantas na produção de frutos do tomateiro (Lycopersicon esculentum Mill.). In: CONGRESSO BRASILEIRO DE OLERICULTURA, 22., Vitória, 1982. Resumos. Vitória, SOB: 1982. p.290-292.

BETTIOL, W. http://www.agrisustentavel.com/san /tomato.htm , (15 dez. 2004).

BETTIOL, W.; GHINI, R.; GALVÃO, J.A.H.; SILOTO, R.C. Organic and Conventional tomato cropping systems. Scientia Agrícola, v.61, n.3, p.253259, maio/jun., 2004.

BORDELEAU, G.; MYERS-SMITH, I.; SZEREMETA, A. Food Quality: A comparison of organic and conventional fruit and vegetables. Agrotechnology Department at KVL, Denmark, (The Royal Veterinaruy and Agricultural University). http://kursus.kvl.dk/shars/ea/03projects/32gamle/2002/Food Qulites.pdf

BORGUINI, R. G. Tomate (Lycopersicon esculentum Mill) orgânico: o conteúdo nutricional e a opinião do consumidor. Piracicaba, 2002. 110p. Dissertação (Mestrado) - Escola Superior de Agricultura "Luiz de Queiroz", Universidade de São Paulo.

BRASIL. Lei n. 10.831, de 23 de dezembro de 2003. Diário Oficial da União, 24 dez. 2003. Seção I. Dispõe sobre a agricultura orgânica e outras providencias.

CAMPOS, J. P.; BELFORT, C. C.; GALVÃO, J. D.; FONTES, P. C. R. Efeito da poda de haste e da população de plantas sobre a produção do tomateiro. Revista Ceres, v. 34, n.191, p. 198-208, 1987. 
CAPORAL, F.R.; COSTABEBER, J.A. Agroecologia: alguns conceitos e princípios. Brasília, MDA/SAF/DATER - IICA, 2004. 24p.

CARVALHO, I. A. DE Comportamento de cultivares de tomate de crescimento indeterminado (Licopersicon esculentum Mill.), em ambiente protegido. Piracicaba, 2002. 96p. Tese (Doutorado) - Escola Superior de Agricultura "Luiz de Queiroz", Universidade de São Paulo.

CARVALHO, Y. M. C. Agricultura orgânica e o comércio justo. In. AMBROSANO, E.J. (coord.) Adubação verde para agricultura orgânica Piracicaba: Gráfica e Editora Degaspari, 2000 p. 123-149.

COORDENADORIA DE ASSISTÊNCIA TÉCNICA INTEGRAL Manual técnico das culturas 2 edição Campinas: CATI, 1997. p. 125-132: Tomate.

CERVEIRA, R.; CASTRO, M.C. DE Consumidores de produtos orgânicos na cidade de São Paulo: características de um padrão de consumo. Informações Econômicas , v.29, n.12, p.7-19, 1999.

CLEARGEAU, M.; LATERROT, H.; PITRAT, M. Creátion de varieties, resistants aux maladies chez les plants maraichères. Bulletin Technique d'information, INRA, v. 337, p. 101-114, 1979.

CENTRO DE QUALIDADE EM HORTICULTURA / COMPANHIA DE ENTREPOSTOS E ARMAZÉNS GERAIS DE SÃO PAULO. Programa brasileiro para a modernização da horticultura: Normas para a classificação do tomate. Centro de Qualidade em Horticultura, São Paulo, 2003. (CQH Documento, 26). 
DA SILVA, E. C.; FERREIRA, D. A.; BEARZOTI, E. Avaliação do poder e taxas de erro Tipo I do teste de Scott-Knott por meio do método de Monte Carlo. Ciência e Agrotecnologia, v. 23, n.3, p.687-696, jul/set, 1999.

DIVER, S.; KUEPPER, G.; BORN, H. Organic tomato production. ATTRA, 1999. 25p. (Horticulture Production Guide).

DUNCAN, D. B. Multiple range and multiple F tests. Biometrics, v.21, p.11-42, 1955.

EDWARDS, C. A. The importance of integration in sustainable agricultural systems. Agriculture, Ecosystems and Enviroment, v.27, p. 25-35, 1989.

\section{EMBRAPA,}

https://www.cppse.embrapa.br/meteoro/apresentacao.htm?novapagina=1, (23 DEZ. 2004).

EMPRESA BRASILEIRA DE PESQUISA AGROPECUÁRIA. Sistemas de produção para a cultura do tomate. Miguel Pereira, 1975. 34p. (Circular, 83).

FERREIRA, D. F.; MUNIZ, J. A.; AQUINO, L. H. DE Comparações múltiplas em experimentos com grande número de tratamentos - utilização do teste de Scott-knott. Ciência e Agrotecnologia, v. 23, n.3, p.745-752, jul/set, 1999.

FILGUEIRA, F. A. R. Manual de olericultura - cultura e comercialização de hortaliças. 2 ed. São Paulo: Agronômica Ceres, 1982. v.2, 357p.

FNP CONSULTORIA \& COMÉRCIO. Tomate para mesa, a prioritária exigência de qualidade. Agrianual 2001. São Paulo, 2001. p.65-67. 
GUSMÃO, S. A. L. Efeito da poda e da densidade de plantio sobre a produção do tomateiro (Lycopersicon esculentum Mill.). Viçosa, 1988. 102p. Dissertação (Mestrado) - Universidade Federal de Viçosa.

INOCUIDAD y calidad de los alimentos em relación con la agricultura orgánioca. In: CONFERENCIA REGIONAL DE LA FAO PARA EUROPA, 22., Oporto, 2000. Rome:FAO, 2000.p.1-69.

INSTITUTO BRASILEIRO DE GEOGRAFIA E ESTATÍSTICA. Pesquisa de orçamentos familiares: consumo alimentar domiciliar per capita. Rio de Janeiro, 1998. p.27.

INTERNATIONAL TRADE CENTER UNCTAD/WTO. Organic food and beverages: world supply and major European markets. Geneva, Switzerland: ITC, 1999.

KHATOUNIAN, C.A. A Reconstrução ecológica da Agricultura. Botucatu: Ed. Agroecológica, 2001348 p.

KISS, J. Terra em transe. Globo Rural, n.223, p.34-42, março 2004.

LAIRON, D. Efecto de las fertilizaciones orgánicas y minerales sobre el valor nutritivo de las producciones agrícolas. In: CONGRESSO EUROPEU DE AGRICULTURA BIOLÓGICA, Madrid, 1985. Ponencias y Comunicaciones. Madrid: IFOAM/Asociación Vida Sana, 1985. p.254-271.

LAMPKIN, N. The wider issues. In: Organic farming. Ipswich: Press Book, 1990. cap.15, p.557-616. 
LATERROT, par $\mathrm{H}$. Sélection de variétés de toamte resistentes aux Meloidogyne OEPPIEPPO , v.1, n.3, p.89-92, 1973.

LOGENDRA, L. S. ; GIANFAGNA, T. J. SPECCA, D. R.; JANES, H. W. Greenhouse tomato limited cluster production systems: Crop management practices affect yield. HortScience, v. 36, n. 5, p. 893-896. 2001.

LOPES, C. A.; SANTOS, J. R. M. DOS Doenças do tomateiro Brasília: EMBRAPA SPI, 1994. 61p.

MATSUDA, http://www.matsuda.com.brl, (19 dez. 2004).

MELO, P. C. T. Genética da resistência a nematóides do gênero Meloidogyne spp. em tomateiro (Lycopersicon esculentum Mill.) Piracicaba, 1984. (comunicação pessoal).

MELO, P. C. T.; MIRANDA, J. E. C.; COSTA, C. P. DA Possibilidades do uso de híbridos $F_{1}$ de tomate Horticultura Brasileira, v. 6, n. 2, p. 4-6, nov. 1998.

MELO, P. C. T. Desenvolvimento sustentável da cadeia produtiva do tomate pra consumo in natura no Brasil e os desafios do melhoramento genético. Horticultura Brasileira, v.21, n. 2, julho, 2003.

MINAMI, K.; HAAG, P. H. O tomateiro. 2. ed. Campinas: Fundação Cargill, 1989. 397p.

NAGAI,H. Hortaliças - Tomate. In: Melhoramento de plantas no Instituto Agronômico. Campinas: Fundação IAC, 1993, v. 1, p. 301. 
NEVES, E.M.; RODRIGUES, L.; DAYOUB, M.; DRAGONE, D.S. Bataticultura: Dispêndios com defensivos agrícolas no qüinqüênio 1997-2001. Batata Show, n. 6, p. 22-23, mar., 2003.

NOTICERES Informativo técnico Horticeres. V. 4, n. 18, 8p. dez, 2004.

NUEZ, F. Cultivo Del tomate. Madri: ed. Mundi-Prensa 1995. 793p.

OLIVEIRA, V. R.; CAMPOS, J. P.; FONTES, P. C. R.; REIS, F. P . Efeito do número de hastes por planta e poda apical na produção classificada de frutos de tomateiro (Lycopersicon esculentum Mill.). Ciência e Prática, v. 19, n. 4, p. 414-419, out/dez, 1995a.

OLIVEIRA, V. R.; OLIVEIRA JUNIOR, R. S. DE; MELO, V. F.; FONTES, P. C. R.; REIS, F. P . Distribuição da produção de frutos nos cachos de cinco cultivares de tomate (Lycopersicon esculentum Mill.). Revista Ceres, v. 42, n. 244 , p. 644-657, nov/dez, 1995b.

ORMOND, J.G.P.; PAULA, S.R.L; FAVERET FILHO, P.; ROCHA, L.T.M. Agricultura Orgânica: Quando o passado é futuro. Rio de Janeiro: 2002. p. 3-34. (Bndes Setorial, n. 15).

PASCHOAL, A. D. Produção orgânica de alimentos : agricultura sustentável para os séculos XX e XXI. Piracicaba: EDUSP, 1994. 323p.

PEÑA, R.P. Rendimento, qualidade e conservação pós-colheita de cenoura (Daucus carota L.) sob adubações mineral, orgânica e biodinâmica. Botucatu, 1996. 93p. Dissertação (Mestrado) - Faculdade de Ciências Agronômicas, Universidade Estadual Paulista "Julio Mesquita Filho". 
PENTEADO, S. R. Cultivo orgánico de tomate Viçosa: Ed. Aprenda Fácil, 2004214 p.

POERSCHKE, P. R. C.; BURIOL, G. A.; STRECK, N. A.; ESTEFANEL, V. Efeito de sistemas de poda sobre o rendimento do tomateiro cultivado em estufa de polietileno. Ciência Rural, v. 25, n. 3, p.379-384, set/dez, 1995.

PRIMAVESI, A.M. Fundamentos da Agroecologia. In: SEMINÁRIO DE AGRICULTURA ORGÃNICA E FAMILIAR. Campinas, 2001 Anais Campinas: CATI, 2001. p.23-30

SALANI, F. Brasil 'caça' processadores de orgânicos. Folha de São Paulo, São Paulo, 22 fev. 2002. p.B12.

SCHUPHAN, W. Nutritive value of crops as influenced by organic and inorganic fertilizer treatment. Qualitas Plantarum: plant foods for human nutrition, v.23, n.4, p.333-358, 1974.

SCOTT, A.J.; KNOTT, M.A. A cluster analysis method for grouping means in the analysis of variance. Biometrics, Washington, v.30, n.3, p.507-514, Sept, 1974.

SILVA JUNIOR, A. A.; MULLER, J. J. V.; PRANDO, H. F. Poda e alta densidade de plantio na cultura do tomate. Revista Agropecuária Catarinense, v. 5, n. 1, p. 57-61, 1992.

SMITH, B.L. Organic foods vs. supermarket foods: element levels. Journal of Applied Nutrition, v. 45, n.1, p.35-39, 1993. 
SOUZA, M.C.M. Produtos orgânicos; In: ZYLBERSZTAJN, D.; NEVES, M.F. (Org). Economia e gestão dos negócios agro-alimentares. São Paulo: Pioneira, 2000. cap. 17.

SPERS, E.E.; KASSOUF, A.L. A abertura do mercado e a preocupação com a segurança dos alimentos. Higiene Alimentar, v.10, n.46, p.16-26, 1996.

STRECK, N. A.; BURIOL, G. A.; ANDRIOLO, J. L. ET AL. Influencia da densidade de plantas e da poda apical drástica na produtividade do tomateiro em estufa de plástico. Pesquisa Agropecuária Brasileira, v. 33, n. 7, p. 1105-1112, 1998.

TUZEL, Y.; OZTEKIN, G.B.; ONGUN, A.R. GUMUS, M.; TUZEL, I.H.; ELTEZ, R.Z. ACTA HORTICULTURAE, n. 659, p. 729-736, 2004. /Apresentado ao $6^{\circ}$ International Symposium on protected cultivation in mild winter climate. Abstract

UNDERHILL, S. E.; FIGUEROA, E. E. Consumer preferences for nonconventionally grown produce. Journal of Food Distribution Research, v. 27, n.2, p. 56-66, Jul., 1996.

VAN BRUGGEN, A.H.C. Plant disease in high-input compared to reduced-input and organic farming systems. Plant Disease, v.79, p. 976-984, 1995. 